\title{
A STUDY OF THE CORROSIVE EFFECT ON ALUMINUM AND
} CP TITANIUM OF MIXTURES OF AMMONIA AND SEAWATER THAT MAY BE ENCOUNTERED IN OTEC HEAT EXCHANGERS

Final Report

C. F. Schrieber

W. D. Grimes

W. F. McIlhenny

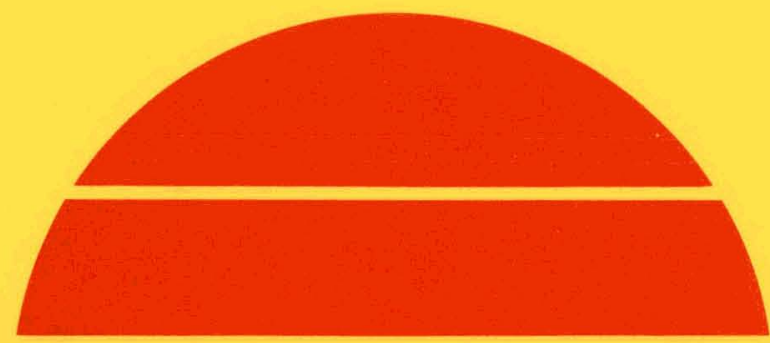

Argonne National Laboratory

9700 South Cass Avenue Argonne, Illinois 60439

Prepared for the

U. S. Department of Energy

Division of Central Solar Technology under Contract W-31-109-Eng-38 


\section{DISCLAIMER}

This report was prepared as an account of work sponsored by an agency of the United States Government. Neither the United States Government nor any agency Thereof, nor any of their employees, makes any warranty, express or implied, or assumes any legal liability or responsibility for the accuracy, completeness, or usefulness of any information, apparatus, product, or process disclosed, or represents that its use would not infringe privately owned rights. Reference herein to any specific commercial product, process, or service by trade name, trademark, manufacturer, or otherwise does not necessarily constitute or imply its endorsement, recommendation, or favoring by the United States Government or any agency thereof. The views and opinions of authors expressed herein do not necessarily state or reflect those of the United States Government or any agency thereof. 


\section{DISCLAIMER}

Portions of this document may be illegible in electronic image products. Images are produced from the best available original document. 
The facilities of Argonne National Laboratory are owned by the United States Government. Under the terms of a contract (W-31-109-Eng-38) among the U.S. Department of Energy, Argonne Universities Association and The University of Chicago, the University employs the staff and operates the Laboratory in accordance with policies and programs formulated, approved and reviewed by the Association.

\section{MEMBERS OF ARGONNE UNIVERSITIES ASSOCIATION}

The University of Arizona Carnegie-Mellon University Case Western Reserve University The University of Chicago University of Cincinnati Illinois Institute of Technology University of Illinois Indiana University The Iniversity of Inwa Iowa State Univer sity
The University of Kansas Kansas State University Loyola University of Chicago Marquette University The University of Michigan Michigan State University University of Minne sota University of Missouri Northwe stern ITniversity University of Notre Dame
The Ohio State University Ohio University The Pennsylvania State University Purdue University Saint Louis University Southern Illinuis University The University of Texas at Austin Washington Univer sity Wayrne State Iniversity The University of Wisconsin-Madison

\section{NOTICE}

This report was prepared as an account of work sponsored by the United States Government. Neither the United States nor the United States Department of Energy, nor any of their employees, nor any of their contractors, subcontractors, or their employees, makes any warranty, express or implied, or assumes any legal liability or responsibility for the accuracy, completeness or usefulness of any information, apparatus, product or process disclosed, or represents that its use would not infringe privately-owned rights. Mention of commercial products, their manufacturers, or their suppliers in this publication does not imply or connote approval or disapproval of the product by Argonne National Laboratory or the U. S. Department of Energy.

Printed in the United States of America Available from

National Technical Information Service

U. S. Department of Commerce 5285 Port Royal Road

Springfield, Virginia 22161

Price: Printed Copy $\$ 7.25$; Microfiche $\$ 3.00$

$$
6.58
$$


ANL/OTEC-BCM-004

\title{
Argonne National Laboratory \\ 9700 South Cass Avenue \\ Argonne, Illinois 60439
}

\begin{abstract}
A STUDY OF THE CORROSIVE EFFECT ON ALUMINUM AND CP TITANIUM OF MIXTURES OF AMMONIA AND SEAWATER THAT MAY BE ENCOUNTERED IN OTEC HEAT EXCHANGERS
\end{abstract}

\author{
Final Report \\ C. F. Schrieber \\ W. D. Grimes \\ W. F. McIlhenny \\ Dow Chemical U.S.A. \\ Texas Division \\ Freeport, Texas 77541
}

March 1979

Prepared under

Subcontract No. B-42805-A-E 
THIS PAGE

\section{WAS INTENTIONALLY LEFT BLANK}


MANAGEMENT SUMMARY.. • . . . . . . . . . . . . . .

I. INTRODUCTION. . . . . . . . . . . . . . . . . 1

II. SUMMARY AND CONCLUSIONS . . . . . . . . . . . . 3

III. EXPERIMENTAL PROCEDURES • • . • • • . . . . . . . 6

A. Program Methodology . . . . . . . . . . . 6

B. Test Unit Description . . . . . . . . . . 6

C. Specimen Procedure . . . . . . . . . . . . 14

IV. AMMONIA IN SEAWATER . . . . . . . . . . . . . 24

A. Scale Formation . . . . . . . . . . . 24

B. Corrosion ... . . . . . . . . . . . . 25

V. SEAWATER IN AMMONIA • . . . . . . . . . . . . . 35

A. Anhydrous Ammonia . . . . . . . . . . . . 35

B. Anhydrous Ammonia plus 0.1\% Seawater. . . . 35

C. Anhydrous Ammonia plus 1.0\% Seawater. • . . 37

D. Anhydrous Ammonia plus 2.5\% Seawater. . . . . . 37

VI. SPECIAL CLEANING TESTS. . . . . . . . . . . . . . 38

VII. RECOMMENDATIONS . . . . . . . . . . . . . . . 40

BIBLIOGRAPHY . . . . . . . . . . . . . . . . . . 4 41

APPENDICES. • . . . . . . . . . . . . . . . . . . 4 42

A. Detailed Tabular Data . . . . . . . . . 42

B. Equipment and Soale Photographs . . . . . . 98 


\section{LIST OF FIGURES}

I-1. Weight Losses for $1100,3003,5052$, and

$\underline{\text { Page }}$ 6063 Alloys Exposed One Month in 0-100\% Ammonia-Seawater Solutions (from Bonewitz, July 1977)

III-1. Simplified Flowsheet of Corrosion Test Units to Determine Effect of Low Conc. of $\mathrm{NH}_{3}$ in Seawater (Units $\left.1 \& 2\right) \ldots \ldots \ldots \ldots \ldots$

III-2. Simplified Flowsheet of Corrosion Test Unit to Determine Effect of Low Conc.

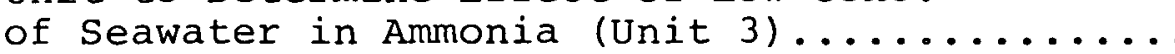

III-3. Flowsheet for Installation of Cleaning Loss Specimens and Uncontaminated Corrosion-scaling Controls ; . . . . . . .......

III-4. Incoming Seawater Temperature at Dow Chemical Company, Freeport,

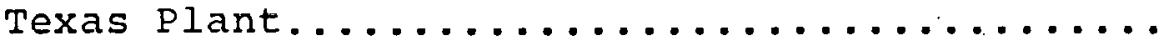

III-5. Teflon Weight-Loss and Pitting Specimen

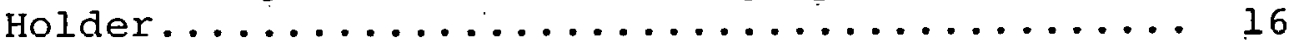

III-6. Specimen Holder Scheme............... 17

III-7. Crevice Corrosion Specimen Assembly......... 18

III-8. Alloy Corrosion Performance: Penetration

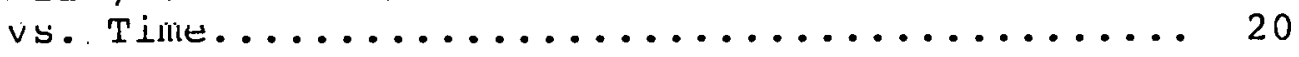

III-9. Brush Arrangement Used for Mechanical

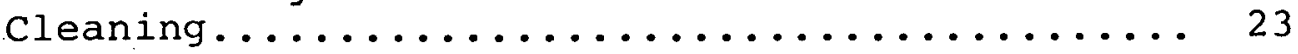

IV-1. Fouling Formation.................. 26

IV-2. Ammonia Concentration vs. $\mathrm{pH} \ldots \ldots \ldots \ldots \ldots \ldots$

IV-3. Scale Composition and Formation........... 28

IV-1. Suale Furllation on Crcvice Test $\Lambda$ sembly,

$880 \mathrm{ppm}$ Ammonia in Seawater at $30^{\circ} \mathrm{C} \ldots \ldots \ldots . \ldots 29$

IV-5. Corrosion Summary: Final Interval

Corrosion Rate and Maximum Pit Depth,

Seawater. Mixed with Ammonia, Evaporator,

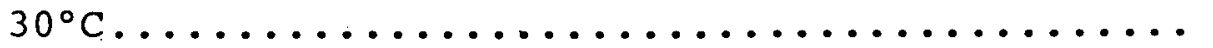


IV-6. Corrosion Summary: Final Interval Corrosion Rate and Maximum Pit Depth, Seawater Mixed with Ammonia, Condensor,

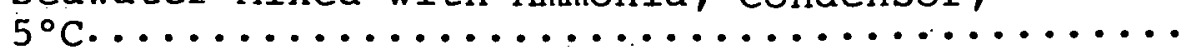

V-1. Corrosion Summary: Final Interval Corrosion Rate and Maximum Pit Depth, Ammonia Mixed with Seawater, Condensor,

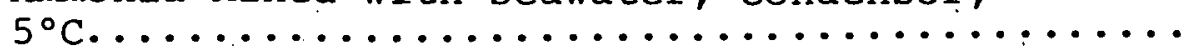

VI-1.. Total Average Penetration vs. Cleaning Method..

IX-1. Test Unit 1: Seawater Mixed with Ammonia

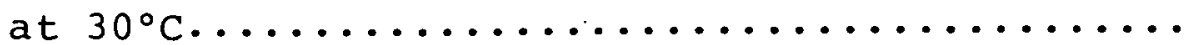

IX-2. Test Unit 2: Seawater Mixed with Ammonia at

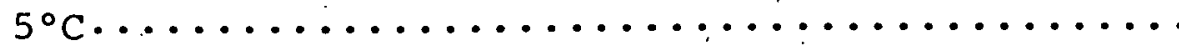

IX-3. Test Unit 3: Liquid Anhydrous Ammonia Mixed with Seawater at $5^{\circ} \mathrm{C} \ldots \ldots \ldots \ldots \ldots \ldots \ldots \ldots \ldots$

IX-4. Test Unit 4: Once Through Ambient Temperature Seawater System for Cleaning Test and Seawater

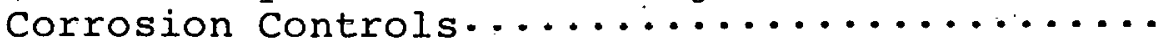

IX-5. ' Crevice Corrosion Specimen Assembly..........

IX-6. Fouling on Crevice Test Assembly, $8 \mathrm{ppm}$ Ammonia in Seawater at $5^{\circ} \mathrm{C}$ and $30^{\circ} \mathrm{C} \ldots \ldots \ldots \ldots$

IX-7. Scale Formation on Crevice Test Assembly, $30 \mathrm{ppm}$ Ammonia in seawater at $5^{\circ} \mathrm{C}$ and $30^{\circ} \mathrm{C} \ldots .$.

IX-8. Scale Formation on Crevice Test Assembly, $83 \mathrm{ppm}$ Ammonia in Seawater at $30^{\circ} \mathrm{C} \ldots \ldots \ldots \ldots . . . .106$

IX-9. Scale Formation on Crevice Test Assembly, $78 \mathrm{ppm}$ Ammonia in seawater at $5^{\circ} \mathrm{C}$.

IX-10. Scale Formation on Crevice Test Assembly, $880 \mathrm{ppm}$ Ammonia in Seawater at $30^{\circ} \mathrm{C} \ldots \ldots . . . . .108$

IX-11. Scale Formation on Crevice Test Assembly, $916 \mathrm{ppm}$ Ammonia in Seawater at $5^{\circ} \mathrm{C}$ 


\section{LIST OF TABLES.}

$\underline{\text { Page }}$

III-1. Final Program Methodology................7

III-2. Seawater Composition and Range -

Gulf of Mexico........................ 12

III-3. Chemical Composition or Specification

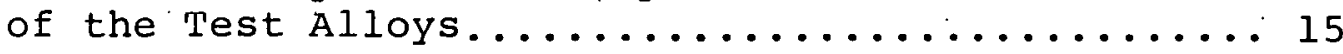

IV-1. Total Average Penetration of Ambient

Temperature Seawater Controls............... 33

IX-1. Final Interval Corrosion Rate (mpy) for

Ambient Temperature Seawater Controls...........

IX-2. Final Interval Corrosion Raies for

Test Exposures of $8.0 \mathrm{ppm}$ Ammonia in

Seawater........................... 4

IX-3. Total Average Penetration (mils) for

Test Exposures of $8.0 \mathrm{ppm}$ Ammonia in

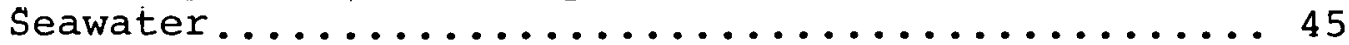

IX-4. Corrosion Data for Test - $30^{\circ} \mathrm{C}$ Seawater +

$7.5 \mathrm{ppm}$ Ammonia...................... 46

1X-5. Corrosion Data tor Test - $5^{\circ} \mathrm{C}$ Seawater +

$8.5 \mathrm{ppm}$ Ammonia....................... 49

$1 \mathrm{x}-\mathrm{b}$. Fouling Formation - Seawater + Nominal

$8.0 \mathrm{ppm}$ Ammonia and Ambient Temperature

Seawater Controls...................... 51

IX-7. Summary of Exposure Conditions - Nominal

$8 \mathrm{ppm} \mathrm{NH}_{3} \ldots \ldots \ldots \ldots \ldots \ldots \ldots \ldots \ldots \ldots \ldots \ldots \ldots \ldots . \ldots \ldots \ldots$

IX-8. Final Interval Corrosion Rates for Test

Exposures of $30.0 \mathrm{ppm}$ Ammonia in Seawater....... 53

IX-9. Total Average Penetration (mils) for Test

Exposures of $30 \mathrm{ppm}$ Ammonid in scownter........ 54

IX-10. Corrosion Data for Test $-30^{\circ} \mathrm{C}$ Seawater +

$27.2 \mathrm{ppm}$ Ammonia....................... 55

IX-11. Corrosion Data for Test - 5. C Seawater +

$26.6 \mathrm{ppm}$ Ammonia..................... 57

IX-12. Fouling Formation - Seawater + Nominal

$30 \mathrm{ppm}$ Ammonia and Ambient Temperature

Seawater Controls....................... 59 
IX-13. Summary of Exposure Conditions - Nominal

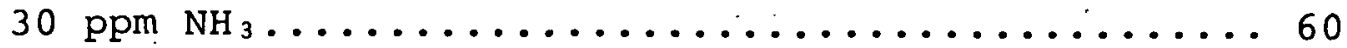

IX-14. Final Interval Corrosion Rates for Test Exposures of $80 \mathrm{ppm}$ Ammonia..............61

IX-15. Total Average Penetration (mils) for Test Exposures of $80 \mathrm{ppm}$ Ammonia in Seawater......... 62

IX-16. Corrosion Data for Test - $30^{\circ} \mathrm{C}$ Seawater +

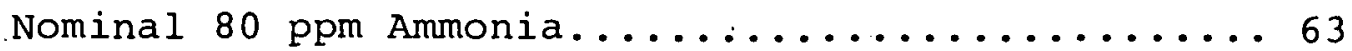

IX-17. Corrosion Data for Crevice Corrosion Test $30^{\circ} \mathrm{C}$ Seawater $+83 \mathrm{ppm}$ Ammonia for 50 Days....... 65

IX-18. Corrosion Data for Test $-7^{\circ} \mathrm{C}$ Seawater + Nominal $80 \mathrm{ppm}$ Ammonia.................. 66 .

IX-19. Corrosion Data for Crevice Corrosion Test $7^{\circ} \mathrm{C}$ Seawater +78 ppm Ammonia for 51 Days....... 68

IX-20. Scale Formation - Seawater + Nominal $80 . \mathrm{ppm}$ Ammonia............................... 69

IX-21. Summary of Exposure Conditions ( $280 \mathrm{ppm} \mathrm{NH}_{3}$ l.... 70

IX-22. Final Interval corrosion Rates (mpy) for Test Exposures of $800 \mathrm{ppm}$ Ammonia in

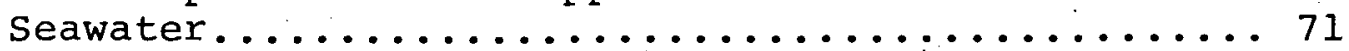

IX-23. Total Average Penetration (mils) after Ten Days for Test Exposures of $800 \mathrm{ppm}$ Ammonia in Seawater................... 72

IX-24. Corrosion Data for Test $-30^{\circ} \mathrm{C}$ Seawater +800 ppm Ammonia...................... 73

IX-25. Corrosion Data for Test $-5^{\circ} \mathrm{C}$ Seawater + $916 \mathrm{ppm}$ Ammonia....................... 74

IX-26. Scale Formation - Seawater +800 ppm Ammonia..... 75 IX-27. Summary of Exposure Conditions ( $\left.200 \mathrm{ppm} \mathrm{NH}_{3}\right) \ldots . .76$ IX-28. Corrosion Data for Test - Final Interval Corrosion Rates - Ammonia plus seawater at $5^{\circ} \mathrm{C} \ldots .77$ IX-29. Corrosion Data for Test $-5^{\circ} \mathrm{C}$ Anhydrous

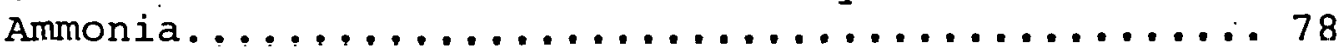


IX-30. Summary of Exposure Conditions for Anhydrous

Ammonia Test........................ 80

IX-31. Total Average Penetration (mils) for a Test Exposure in Anhydrous Ammonia $+.14 \%$ Seawater

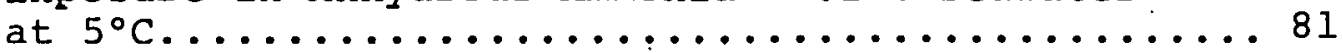

IX-32. Corrosion Data for Crevice Corrosion Test Anhydrous Ammonia $+.14 \%$ Seawater at $5^{\circ} \mathrm{C}$

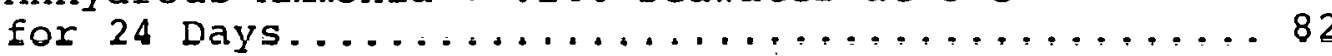

IX-33. Summary of Exposure Conditions for Anhydrous

Alluturida Test Pes iuds.................... 83

IX-34. Corrosion Data for Test $-5^{\circ} \mathrm{C}$

Anhydrous Ammonia $+1.12 \%$ Seawater........... 84

IX-35. Summary of Exposure Conditions

for Anhydrous Ammonia + 18 Seawater

Test Periods.......................... 86

IX-36. Corrosion Data for Test $-5^{\circ} \mathrm{C}$ Anhydrous

Ammonia $+2.5 \%$ Seawater.................. 87

IX-37. Summary of Exposure Conditions for

Anhydrous Ammonia $+2.5 \%$ Seawater............ 89

IX-38. Cleaning Solution Screening - Test

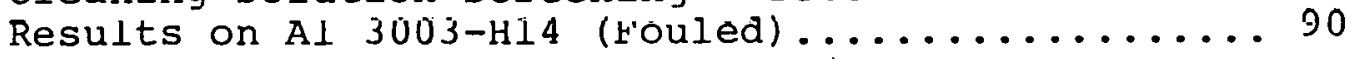

IX-39. Cleaning Tests: Corrosion Summary

Final Interval Corrosion Rate (mpy).......... 91

IX-40. Cleaning Tests: Corrosion Sumuary

Total Average Penetration (mpy).............. 92

IX-41. Cleaning Tests - Ambient Temperature

Unfiltered Seawater.................... 93 


\section{MANAGEMENT SUMMARY}

The design currently most favored for an offshore Thermal Energy Conversion power plant would use an ammonia cycle energy system as powered by the small thermal differences existing between warm surface and deep ocean waters. A possibility therefore exists for ammonia or seawater leakage within the evaporator or condenser. The objective of this work is to assess the extent to which small concentrations of seawater would affect corrosion of aluminum and CP titanium by ammonia and the extent to which small concentrations of ammonia might affect the same alloys by seawater.

Testing was conducted using coupons of aluminum alloys 3003-H14, 5052-H32, and 5086-H32, CP titanium, and aluminum alloy 5052-H32 as pretreated for 8 hours in boiling deionized water. Four pilot units were constructed to investigate different possible OTEC heat exchanger environments. Experimentation on ammonia leakage into seawater employed two 'units containing recirculating ( 6 gal.), temperature-controlled $\left(5^{\circ} \mathrm{C}\right.$ or $\left.30^{\circ} \mathrm{C}\right)$ seawater at 5.6 and 2.5 fps with continuous seawater refreshment $(2.0-0.5 \mathrm{gpm})$. Ammonia leakage was simulated in these two units by injection of ammonia hydroxide into the refreshment seawater. A third unit with the same seawater supply utilized seawater on a once-through, 5 fps, ambient temperature basis to simulate optimum, no-leak OTEC seawater service. Performance of the subject alloys in ammonia and ammonia containing seawater utilized recirculating ammonia with temperature controlled to $5^{\circ} \mathrm{C}$.

Exposures were completed for nominal $8,30,80$, and $800 \mathrm{ppm}$ additions of ammonia to seawater at $5^{\circ} \mathrm{C}$ and $30^{\circ} \mathrm{C}$. The change in $\mathrm{pH}$ resulting from the ammonia addition has resulted in scaling at all ammonia concentrations, with calcite formation followed by aragonite and then brucite as concentrations increased. It is anticipated that a continuous cleaning process could control scale at $8 \mathrm{ppm}, 30^{\circ} \mathrm{C}$ and $5^{\circ} \mathrm{C}$, and at $30 \mathrm{ppm}, 5^{\circ} \mathrm{C}$, but that scaling at $80 \mathrm{ppm}$ and $800 \mathrm{ppm}$ additions is not economically controllable. Corrosion has been minimal except for measureable pitting on $A I$ 3003, Al 5052, Al 5086 at $8 \mathrm{ppm}, 30^{\circ} \mathrm{C}$, and on Al 5052 at $8 \mathrm{ppm}$, $5^{\circ} \mathrm{C}$. Ambient temperature seawater controls show general corrosion attack but insignificant pit attack.

Exposures were also completed for $0,0.1,1.0$, and 2.5 응 nominal seawater additions to commercially pure ammonia at $5^{\circ} \mathrm{C}$. Both corrosion and scaling have been minimal for these exposures.

Exposures reported herein indicate $C P$ titanium will give superior performance in an OTEC heat exchanger followed by pretreated aluminum alloy 5052 .

Results contained in this report are based on limited surface area specimens and should not be used to wholly qualify or disqualify an alloy for consideration in the oTEC application. 


\section{INTRODUCTION}

A principal Ocean Thermal Energy Conversion (OTEC) concept under consideration is based upon the use of an ammoniacycle generator system powered by small thermal differences available between surface and deep ocean waters. The purpose of this contractual effort was to assess the influence of seawater-ammonia mixtures on proposed OTEC heat exchanger materials at environmental conditions which may possibly be encountered in OTEC heat exchangers.

Testing was to remain on a coupon test scale, and relevant information sought included degree and definition of chemical scaling, average uniform penetration, final test interval corrosion rate, pitting, crevice corrosion, and influence of intermittent but sequential chemical and mechanical cleaning. Heat exchanger materials, as proposed by the Department of Energy included commercially pure (CP) titanium, and aluminum alloys 3003, 5052, and 5086. Additionally, at the recommendation of Dow personnel, specimens of aluminum alloy 5052, as pretreated in boiling deionized water, were included in all exposures.

The possibility of either an ammonia or seawater intrusion (leak) in either the OTEC evaporator or condenser, constituted the stimulus for this research on candidate. OTEC heat exchanger materials. The concern was that low concentrations of ammonia in seawater, and conversely, low concentrations of seawater in ammonia, may act to seriously impair material. performance. Previous work, as shown in Figure I-l (Bonewitz, July 1977) has indicated that aluminum alloys may suffer accelerated attack under these conditions. 
FIGURE I-I

WEIGHT LOSSES FOR $1100(\bullet), 3003(\nabla), 5052(\Delta)$ and $6.063(\odot)$ ALLOYS EXFOSED ONE MONTH IN 0-100\% AMMONIA-SEAWATER SCLUTIONS

(from Eonewitz, July, 1977)

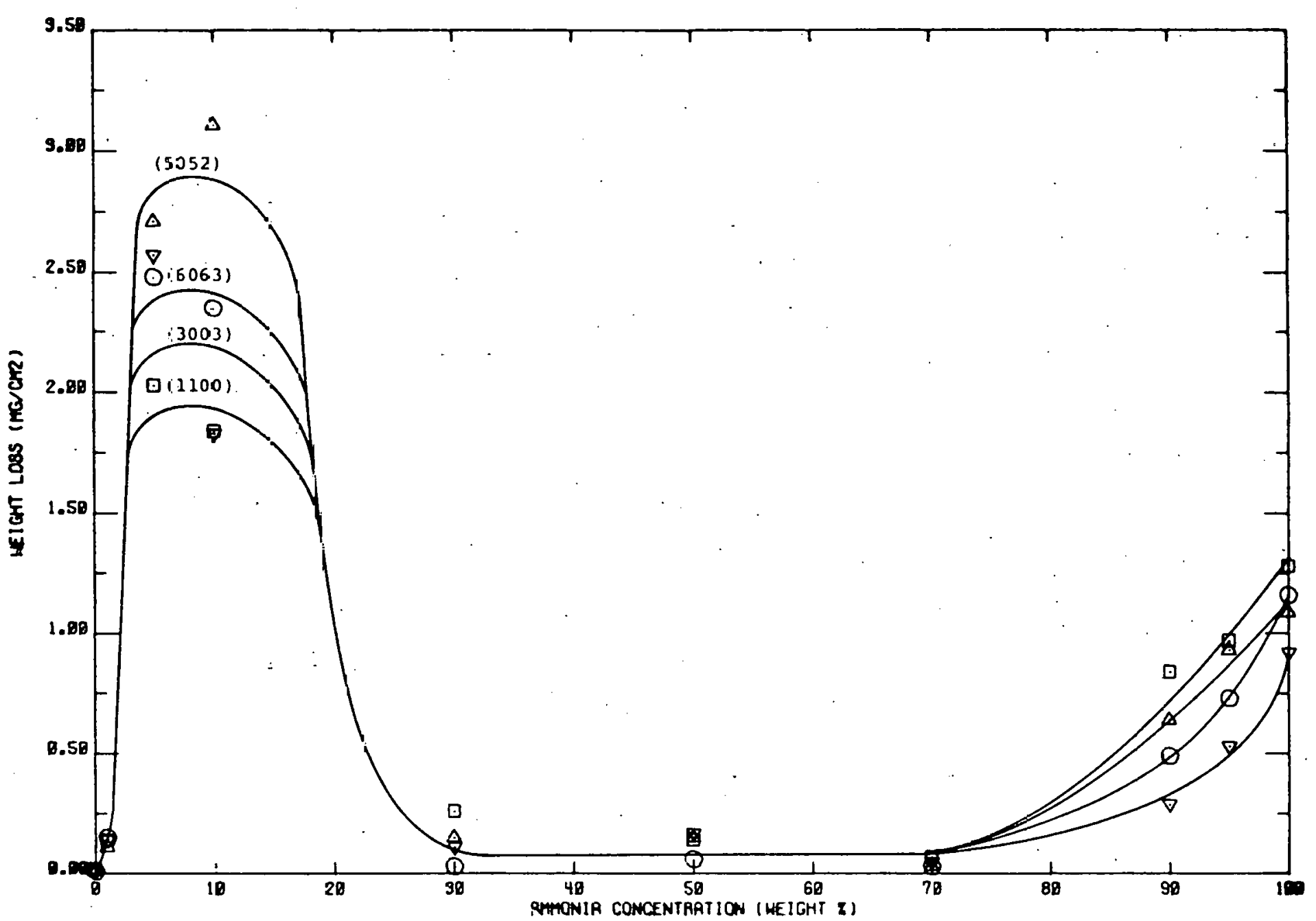




\section{SUMMARY AND CONCLUSIONS}

Tests were conducted to assess scaling and corrosion behavior of CP titanium and aluminum alloys in environments which may possibly be encountered in OTEC heat exchangers. Results of this effort are summarized by the following:

1. In all cases CP titanium performed in a manner superior to that of the aluminum alloys tested. Final interval corrosion ${ }^{1}$ rates for this material were less than $0.0028 \mathrm{~mm} / \mathrm{yr}(0.11 \mathrm{mpy})$ in all environments tested. This compares to final interval corrosion rates of $0.065 \mathrm{~mm} / \mathrm{yr}$ (2.6 mpy) for aluminum alloys in seawater and $0.0074 \mathrm{~mm} / \mathrm{yr}$. (0.29 mpy) in ammonia. Pit and crevice attack was minimal, and no significant penetration (>1 mil) was observed at any exposure. In contrast, pit attack of varying degrees was observed on all aluminum alloys tested.

Additionally, chemical scales forming on titanium surfaces were less tenacious and therefore more readily removed than scales which formed on the aluminum surfaces. CP titanium also showed negligible corrosion rates in the limited scope 10-month mechanical and chemical cleaning tests.

2. Aluminum alloy 5052, which had been pretreated by immersion in boiling deionized water for 8 hours, was the best performer of the aluminum alloys tested. The pretreated aluminum concept was inserted in the test program at Dow's recommendation based upon highly encouraging results obtained from corrosion studies completed for the office of Saline Water, U.S. Department of the Interior. The boiling water pretreatment forms an impervious boehmite film on aluminum which prohibits the plating of pit-inducing heavy metal ions. The effect of this pretreatment is to significantly reduce the initially high corrosion rate associated with aluminum.

In ambient temperature seawater, pretreated aluminum alloy 5052 has a final interval corrosion rate of $0.015 \mathrm{~mm} / \mathrm{yr} .(0.59 \mathrm{mpy})$ as opposed to a final

1 "Final Interval" corrosion rate is a predicted long-term corrosion rate which the metal should experience after the surface has become passivated from continued exposure. The methodology involved in calculating this rate is given in Section III.C.3, "Data Resolution". 
interval corrosion rate of $0.056-0.065 \mathrm{~mm} / \mathrm{yr}$. (2.20-2.57 mpy) for untreated aluminum alloys 3003,5052 , and 5086. In mixtures of $30^{\circ} \mathrm{C}$ seawater plus lower concentrations of ammonia, the performance of pretreated aluminum alloy 5052 was also superior to other aluminum alloys, particularly to pit resistance which was minimal in all seawaterammonia mixtures.

In anhydrous ammonia and ammonia-seawater mixtures, pretreated aluminum alloy 5052 showed an initial weight loss greater than that of the untreated aluminum alloys. However, the final interval corrosion rates for the pretreated alloy in this environment were consistently superior to the other alumilum alloys. In addition, the etched surface attack often observed on aluminum alloys was not apparent on pretreated aluminum alloy 5052. The surface appearance of this alloy was virtually unchanged by the exposure to the subject environments.

Scale and fouling removal was observed to occur as readily on pretreated aluminum alloy 5052 as on $C P$ titanium. The effect of abrasive cleaning techniques on the extended performance of this alloy is currently unknown.

3. The addition of ammonia to seawater will result in alkaline scale formation which may impair heat transfer. The increase in $\mathrm{pH}$ resulting from ammonia addition has rcoultcd in scaling at all trial concentrations of ammonia in seawater ( 8 , 30,80 , and $800 \mathrm{ppm}$ ), with calcite scale forming initially followed by aragonite and brucite as concentrations increase. It is anticipated that a continuous cleaning process could control scale at $8 \mathrm{ppm}, 30^{\circ} \mathrm{C}$ and $5^{\circ} \mathrm{C}$, and at $30 \mathrm{ppm}, 5^{\circ} \mathrm{C}$, but that scale control at ammonia concentrations above 8n ppm (scale growth above $0.013 \mathrm{~mm} / \mathrm{day}$ ) is not economically controllable.

4. The addition of seawater to anhydrous ammonia within the scope of these tests has not resulted in any relevant scale formation.

5. The final interval corrosion rates for the aluminum alloys was generally greater in the control ambient temperature seawater than in seawater plus ammonia mixtures. Aluminum alloys 3003, 5052, and 5086 showed final interval corrosion rates of $0.056-$ $0.065 \mathrm{~mm} / \mathrm{yr}(2.20-2.57 \mathrm{mpy})$ in ambient temperature seawater. Treated aluminum alloy 5052 in this 
environment exhibited a rate one-fourth the above or $0.015 \mathrm{~mm} / \mathrm{yr}$. $(0.59 \mathrm{mpy})$. Pitting was minimal in ambient temperature seawater although measureable pitting was observed on the untreated aluminum alloys in seawater containing $8 \mathrm{ppm}$ at $30^{\circ} \mathrm{C}$.

6. Addition to anhydrous ammonia of greater quantities of seawater from $151 \mathrm{ppm}$ to $2.5 \%$ was generally observed to increase the final interval corrosion rate of untreated aluminum alloys 3003, 5052, and 5086. No conclusive observation may be made concerning treated aluminum alloy 5052 and CP titanium.

7. The results of this test were inconclusive in determining a preferred velocity for the OTEC system. 
III. EXPERIMENTAL PROCEDURES

A. Program Methodology

In order to meet the program objectives, an experimental plan was reviewed with Battelle contract personnel on October 27, 1977, in Freeport, Texas. The subsequent occurrence of heavy calcareous scale in the ammonia-in-seawater tests necessitated concentration changes in this portion of the program. In addition, tests to establish ambient temperature seawater corrosion controls were incorporated and run in parallel with all ammonia in seawater tests after January 30 , 1978. The revised, final program methodology is shown in Tahle TTT-1.

\section{B. Test Unit Description}

Four test units were constructed to meet the requirements of the corrosion test program. The exposure conditions required included seawater with small additions of ammonia at $5^{\circ} \mathrm{C}$ and $30^{\circ} \mathrm{C}$, anhydrous ammonia with small additions of seawater at $5^{\circ} \mathrm{C}$, and once-through ambient temperature seawater.

\section{Test Units: Seawater Containing Ammonia}

Two test units designed to test the subject alloys in seawater plus small concentrations of ammonia at $30^{\circ} \mathrm{C}$ and $5^{\circ} \mathrm{C}$ were constructed as depicted in the generalized schematic in Figure III-1. One unit operates at $30^{\circ} \mathrm{C}$ and is temperature controlled by either conling water or steam. The low tompcrature, $5^{\circ} \mathrm{C}$ unit employs an external chiller circuit which removes heat from the loop by a cold glycol-water solution. Units are constructed of plastic-lined steel (polypropylene, Saran ${ }^{\circledR}, T^{2} f l o n{ }^{\circledR}$, and $\left.\operatorname{Kynar}^{\circledR}\right)$ and Alloy 20 stainless steel.

The test units contain approximately 22.7 liters (6 gal.) recirculating seawater. The seawater is refreshed at a rate of 7.6-1.9 1/min. (2.0-0.5 gpm), for a seawater renewal rate and system stabilization period of about 3-12 minutes. Exact blowdown rates for each test are given in Appendix A, Tables IX-7, IX-13, IX-2I, and IX-27.

Ammonia leakage into seawater was simulated by injection of ammonia solution into the refreshment seawater. Adequate mixing was assured by injection downstream of the recirculating pump and the use of aqueous ammonia (ammonium hydroxide) as an injection fluid. Concentrations of ammonia in seawater are routinely obtained by analysis of the system blowdown. Both units contain all instruments necessary for automatic control and failsafe shutdown to prevent specimens from experiencing excessive ammonia concentrations. 
TABLE III-1

FINAL PROGRAM METHODOLOGY

I. SEAWATER MIXED WITH AMMONIA

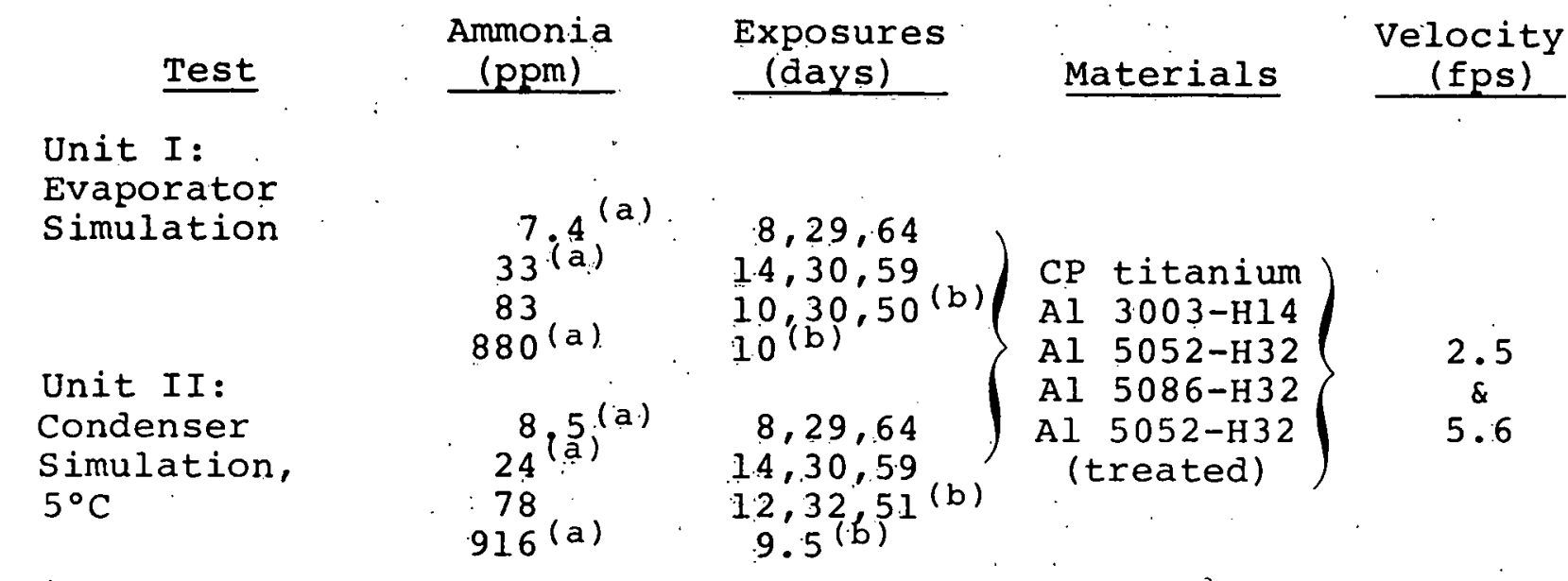

II. AMMONIA MIXED WITH SEAWATER

\begin{tabular}{|c|c|c|c|c|}
\hline Test & Seawater, & $\begin{array}{c}\text { Exposures } \\
\text { (days) } \\
\end{array}$ & Materials & $\begin{array}{c}\text { Velocity } \\
\text { (fps) }\end{array}$ \\
\hline $\begin{array}{l}\text { Unit III: } \\
\text { Condenser } \\
\text { Simulation } \\
5^{\circ} \mathrm{C}\end{array}$ & $\begin{array}{c}(151 \text { ppm) } \\
0.14 \\
1.1 \\
3.3\end{array}$ & $\begin{array}{l}10,40 \\
1.0,24 \\
10,28,59 \\
10,30,53\end{array}$ & $\begin{array}{l}\text { CP titanium } \\
\text { A1 } 3003-\mathrm{H} 14 \\
\text { Al } 5052-\mathrm{H} 32 \\
\text { Al } 5086-\mathrm{H} 32 \\
\text { Al } 5052-\mathrm{II} 32 \\
\text { (treated) }\end{array}$ & $\begin{array}{l}2.5 \\
5.6\end{array}$ \\
\hline
\end{tabular}

III. SPECIAL CLEANING TESTTS

Test

Unit IV:

Ambient

Temperature
Exposure (months)

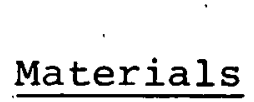

Velocity (fps)

$$
\left.1,3,6,10\} \begin{array}{c}
C P \text { titanium } \\
\text { AI } 3003-\mathrm{H} 14 \\
\text { AI } 5052-\mathrm{H} 32 \\
\text { AI } 5086-\mathrm{H} 32 \\
\text { AI } 5052-\mathrm{H} 32 \\
(\text { treated) }
\end{array}\right\}
$$

(b) Run in parallel with ambient temperature seawater controls

(b) Run in parallel with ambient temperature seawater cont
Terminated early due to extensive calcareous scaling 
Figure III-1

SIMPLIFIED FLOWSHEET OF CORROSION TEST UNITS TO

DETERMINE EFFECT OF LOW CONC. OF $\mathrm{NH}_{3}$ IN SEAWATER (UNITS 1 \& 2)

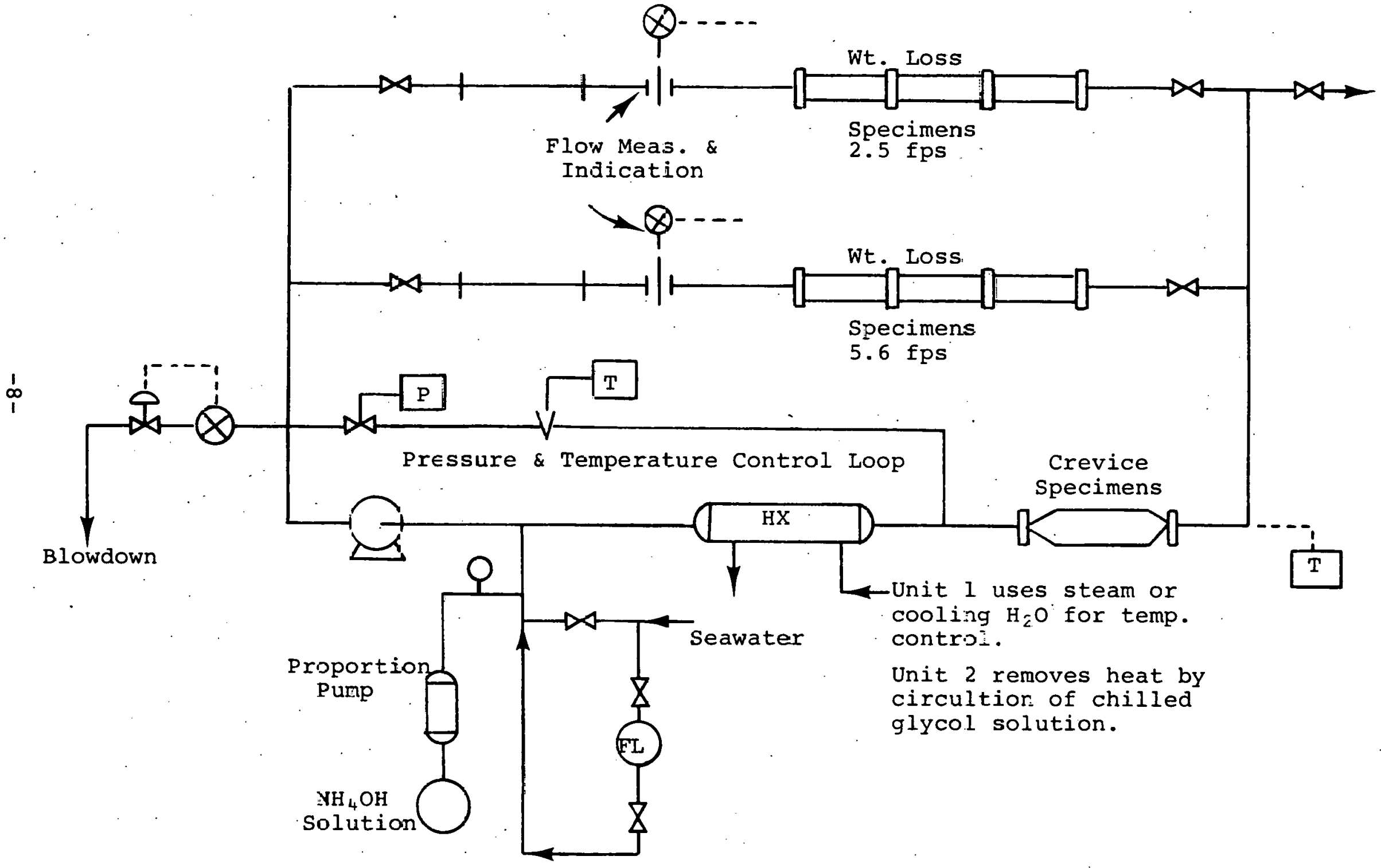




\section{Test Unit: Ammonia Containing Seawater}

A test unit to employ mixtures of anhydrous ammonia plus low concentrations of seawater while operating at $5^{\circ} \mathrm{C}$ was constructed according to the generalized schematic in Figure III-2. Construction material is welded stainless steel 304 alloy, Teflon-lined steel, and Alloy 20 stainless steel. The loop contains a suitable pump, temperature detectors, flow control and monitoring devices, as well, as all automatic controls necessary for failsafe system operation. A chiller is incorporated in the circuit to maintain a $5^{\circ} \mathrm{C}$ environment within the test loop.

The test loop is designed for total recycle of $100 \mathrm{lbs}$. of anhydrous ammonia. The reservoir of anhydrous ammonia-seawater solution so formed created a volume-to-specimen area ratio believed to simulate proposed OTEC conditions. Analysis performed on the ammonia-seawater mixtures included water content, chloride ion concentration, and sodium ion concentration. In Tables IX-30, IX-33, IX-35, and IX-37 detailed analyses of the tests conducted are given.

\section{Seawater Controls and Cleaning Test Unit}

This unit, as depicted in Figure III-3, consists of a oncethrough seawater loop with automatic flow control downstream of the specimens. Cleaning test specimens were exposed to unfiltered seawater while seawater controls were located downstream of the filter. This unit employs ambient temperature seawater, and temperature is not controlled.

\section{Seawater}

Seawater utilized in these tests is from the Gulf of Mexico intake basin located at the Dow Chemical Texas Division industrial site "A" at Freeport, Texas. After large incoming debris is screened out at the Dow intake basin, the seawater is transferred through flumes (canals) to a second smaller sedimentation basin near the OTEC test facility. The seawater is then transferred through a system of copper-free piping to the test units where (with the exception of the cleaning test specimens) the seawater is filtered to contain a maximum particle size of 25 microns. The composition and range of the seawater used in these tests appears in Table III-2.

The variation of seawater temperature for selected years is shown in Figure III-4. Included on this figure are temperatures for the 1978 ambient temperature seawater testing program as well as previous temperature data. This variation is important since seawater temperature may significantly affect corrosion rates. 
Figure III-2

SIMPIIFIED FLOWSHEET OF CORROSION TEST UNIT TO DETERMINE EFFECT OF LOW CONC. OF SEAWATER IN AMMONIA (UNIT 3)

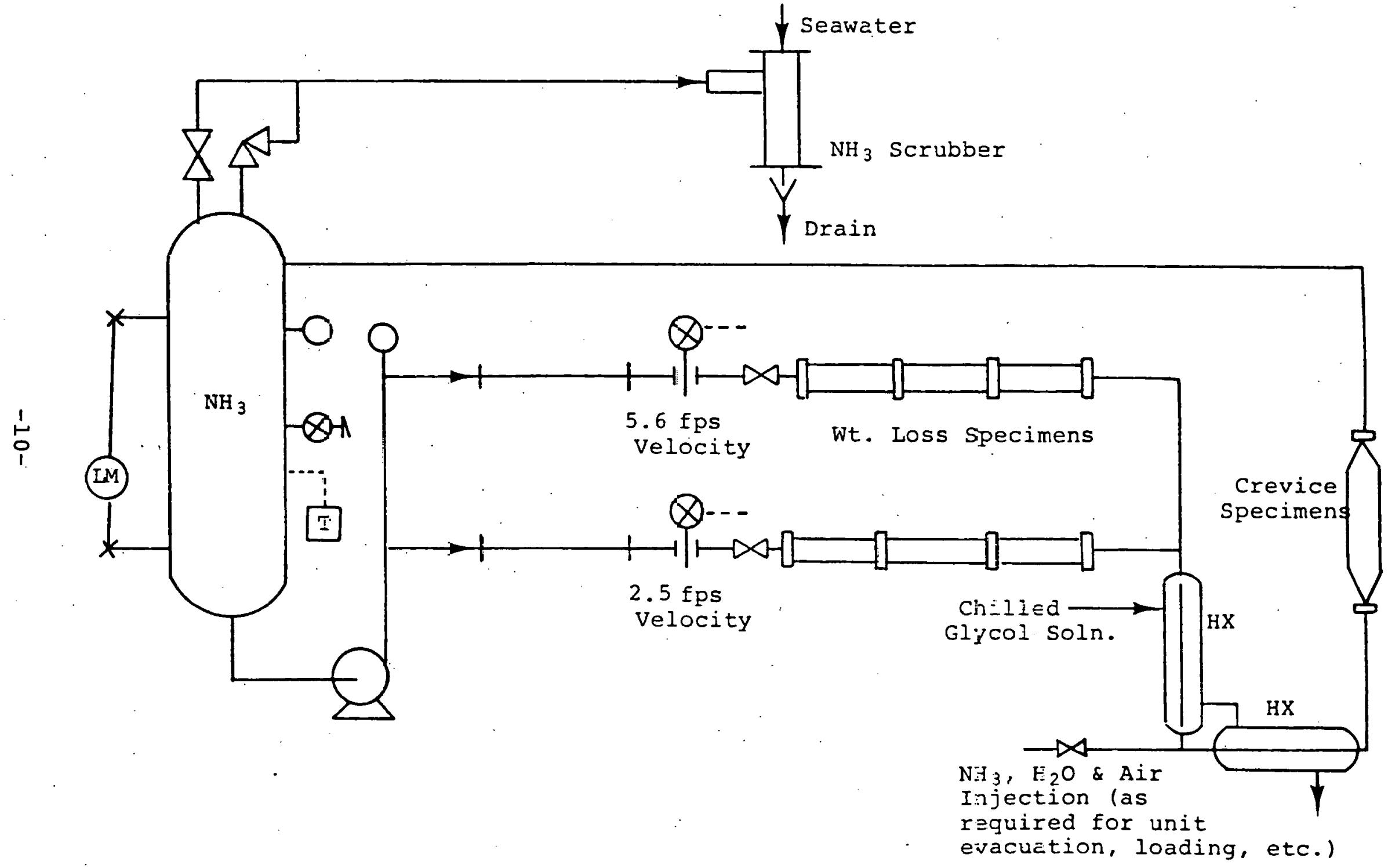


FLOWSHEET ZOR INSTALLATION OF' CLEANING LOSS SPECIMENS AND UNCONTAMINATED CORROSION-SCALING CONTROLS
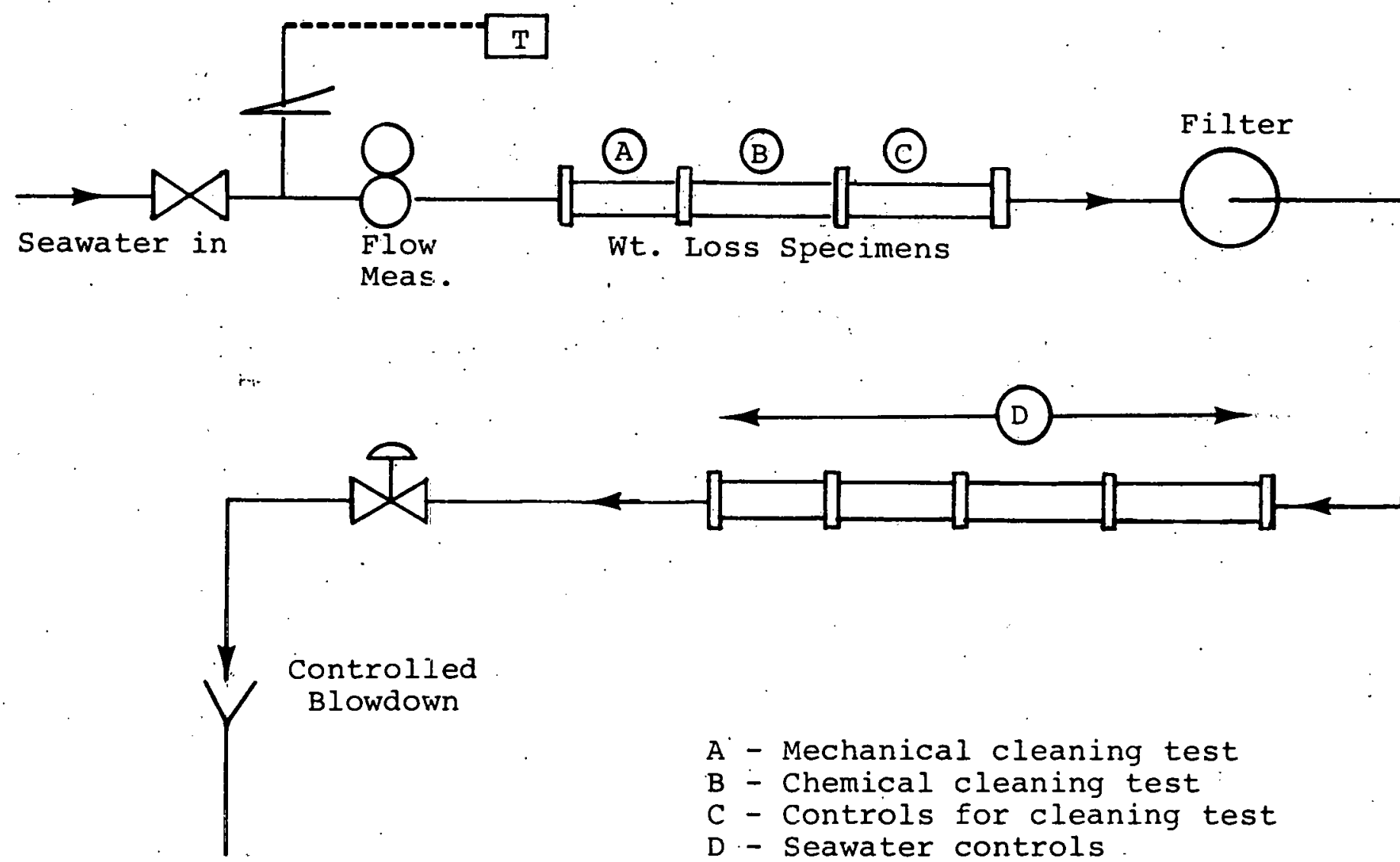
A - Mechanical cleaning test
B - Chemical cleaning test
C - Controls for cleaning test
D - Seawater controls


Table III-2

\section{SEAWATER COMPOSITION AND RANGE GULF OF MEXICO}

\section{Annual Average at Freeport, Texas}

Measured Parameters

Alkalinity as $\mathrm{CaCO}_{3}$

Aluminum as $\mathrm{Al}$

Ammonium ion as $\mathrm{NH}_{4}{ }^{+}$

Calcium as $\mathrm{Ca}$

Carbon Dioxide (free)

$$
\text { as } \mathrm{CO}_{2}
$$

Chloride as $\mathrm{Cl}$

Copper as $\mathrm{Cu}$ (total)

Hydrogen Sulfide as

$$
\mathrm{H}_{2} \mathrm{~S}
$$

Iron as $\mathrm{Fe}$ (total)

Magnesium as $\mathrm{Mg}$

Mercury as $\mathrm{Hg}$

oxygen, dissolved,

$$
\text { as } \mathrm{O}_{2}
$$

$\mathrm{pH}$

Pulasslum as $K$

Salinity, \% "Normal"

Sodium as $\mathrm{Na}$

Sulfate as $\mathrm{SO}_{4}$

Suspended solids

Temperature, ${ }^{\circ} \mathrm{F}$
Range, $\mathrm{mg} / 1$

$75-125$

$-$

$$
1.01-0.1
$$$$
240-400
$$

$$
2-5
$$

$11,700-19,400$

$0.01-0.1 *$

$$
\begin{aligned}
& 0.5-5.0^{*} \\
& 780-1,300
\end{aligned}
$$

$1.5-6.0$

$7.5-8.6$

$230-380$

$$
60-100 \%
$$$$
6,340-10,560
$$$$
1,800-3,000
$$$$
5-50
$$$$
60-.80
$$

Typical Value, Annual Average, $\mathrm{mg} / \mathrm{l}$

100

$$
0.5
$$

0.05

340

3
16,500
0.01
$<0.01$
2
1,100
$<0.0001$
5
8.4
325
$85 \%$
9,000
2,600
20
$70-75$

* Varies with suspended solids present. NOTE: When specific gravity $=1, \mathrm{mg} / \mathrm{l}=\mathrm{ppm}$. 
Figure III-4

INCOMING SEAWATER TEMPERATURE AT

DOW CHEMICAL COMPANY, FREEPORT, TEXAS PLANT
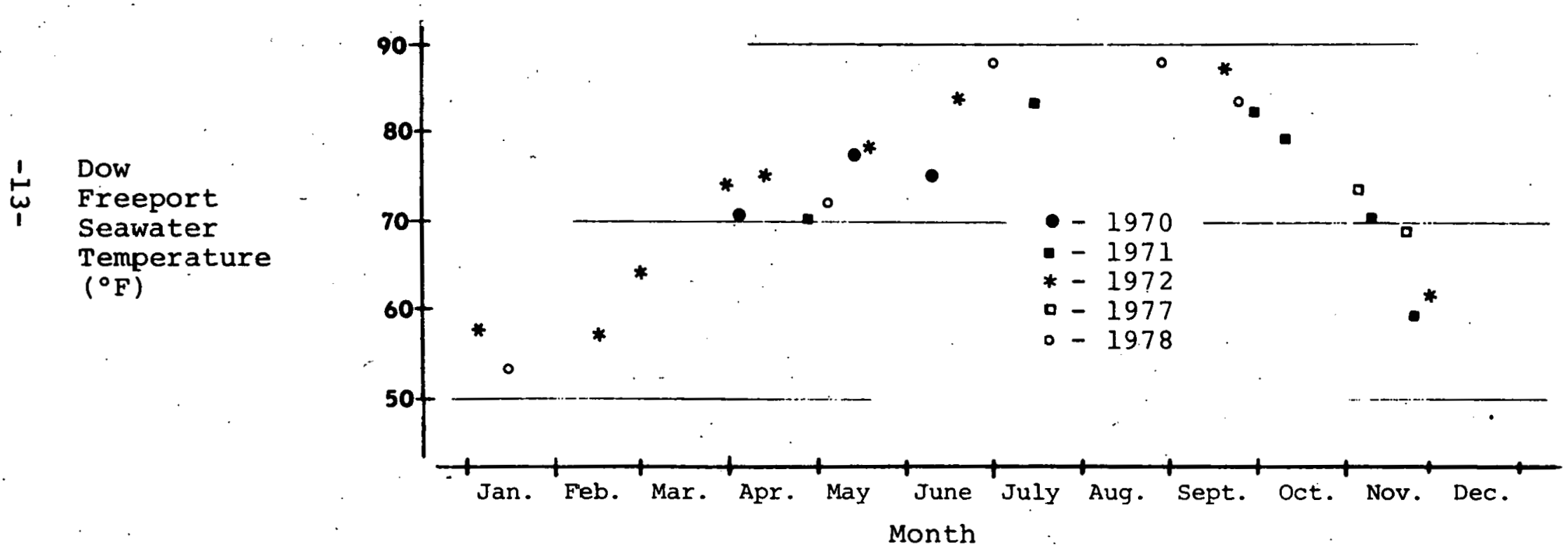


\section{Specimen Procedure}

In the course of these tests, specimens of three aluminum alloys and CP titanium were exposed to determine their corrosion behavior in simulated OTEC environments. Preparation and handing procedures for these specimens were more elaborate than for tubes entering an actual OTEC heat exchanger, but conducted within the recommendations of the National Association of Corrosion Engineers.

\section{Test Alloys}

The alloys specified for use in these tests include aluminum alloys 3003, 5052, and 5086, and CP titanium. Table III-3 shows the chemical specifications for the test alloys.

An addition made by Dow to the test alloy scheme consisted of a sample series of aluminum alloy 5052 pretreated in boiling deionized water for eight hours. One of the findings of the office of Saline Water desalination materials programs indicated that the higher general and pitting corrosion attack of aluminum which occurs during the initial few weeks can be effectively reduced or eliminated by this pretreatment.

\section{Specimen Preparation}

Test requirements dictated that specimen holders be prepared for both crevice and coupon corrosion testing.

General and pitting corrosion rate determinations utilized (6" $x$ 3/4" $\mathrm{x}$ (0.06-0.08)") nominal size coupons. These specimens were held in pipe spools lined with polytetrafluoroethylene (TFE, Teflon $\left.{ }^{\circledR}\right)$ plastic. Fluid velocity past the specimens was accurately fixed by knowledge of the flow rate and available cross sectional area in the holder. Figure III-5 shows a separate coupon holder assembly and Figure III-6 shows the generalized specimen holder scheme.

Crevice corrosion determinations utilized (3" $x 3^{\prime \prime} \times(0.06-$ U.UY)") nominal size specimens with a centered (1/2") diameter hole. These specimens were mounted on a rod holder and individually separated by special crevice contactors. These contacts were specifically designed to form eight crevice areas on each side of the specimen faces with fluid stagnation points between the crevice areas. Contact pressure between separators and specimens was applied from each end of the crevice assembly. All portions of the assembly were fabricated of glass-filled TFE plastic. Mounting of the assembly in the test environment is accomplished through connections at the rod ends. Figure III-7 shows a crevice specimen assembly. 
Table III-3

CHEMICAL COMPOSITION OR SPECIFICATION OF

THE TEST ALLOYS

\begin{tabular}{|c|c|c|c|c|c|c|c|c|c|c|c|}
\hline & Alloy & Si & $\mathrm{Fe}$ & $\mathrm{Cu}$ & Mn & $\mathrm{Mg}$ & $\mathrm{Cr}$ & $\mathrm{Zn}$ & $\mathrm{Ti}$ & Others & Aluminum \\
\hline Al & $3003-\mathrm{H} 14$ & 0.6 & 0.7 & 0.1 & 1.2 & -- & -- & 0.1 & -- & 0.15 & Remainder \\
\hline Al & $5052-\mathrm{H} 32$ & $(0.45 \mathrm{Si}$ & $+\mathrm{Fe})$ & 0.1 & 0.1 & 2.5 & 0.2 & 0.1 & - & 0.15 & Remainder \\
\hline Al & $5086-\mathrm{H} 32$ & 0.4 & 0.5 & 0.1 & 0.4 & 4.0 & 0.1 & 0.2 & 0.15 & 0.15 & Remainder \\
\hline
\end{tabular}

CP Titanium meets Grade 2, ASTM Spec. B265.

NOTE: Aluminum Alloy 5083 was called for in the RFP. Alloy 5086 was substituted with permission because of an availability problem with 5083 . 


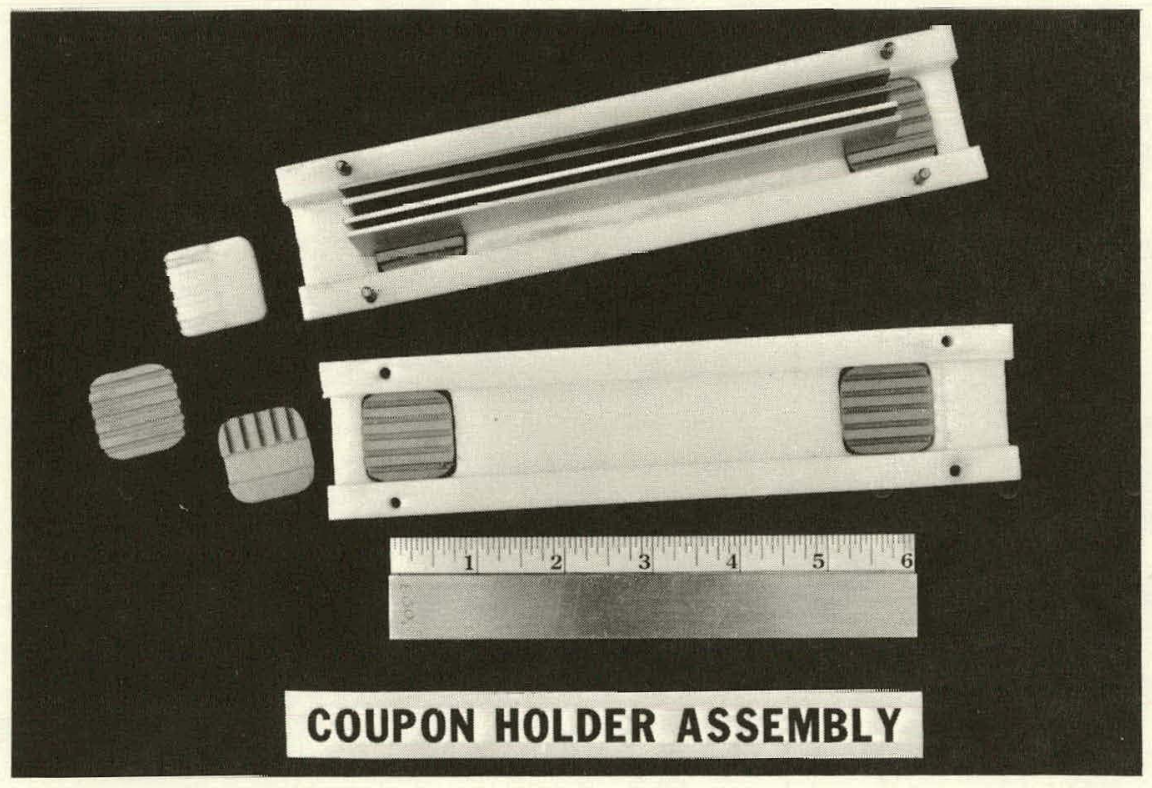

Figure III-5

TEFLON WEIGHT-LOSS AND PITTING SPECIMEN HOLDER 
Figure III-6

SPECIMEN HOLDER SCHEME

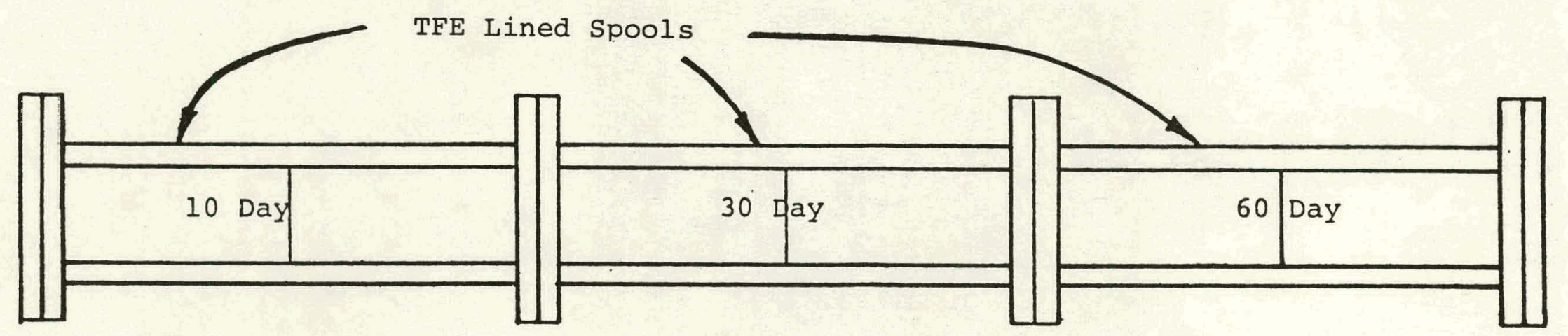

- Each spool contains two TFE specimen holders.

- Each holder contains five specimens, one of each alloy (or alloy condition).

- In the cleaning effects test, the spools contain the above but are designated as follows:

\begin{tabular}{|c|c|c|}
\hline 1 & 1 & 1 \\
\hline $\begin{array}{c}\text { Mechanical } \\
\text { Cleaning } \\
1\end{array}$ & $\begin{array}{c}\text { Chemical } \\
\text { Cleaning }\end{array}$ & $\begin{array}{c}\text { Controls } \\
1\end{array}$ \\
\hline 1 & 1 & 1
\end{tabular}




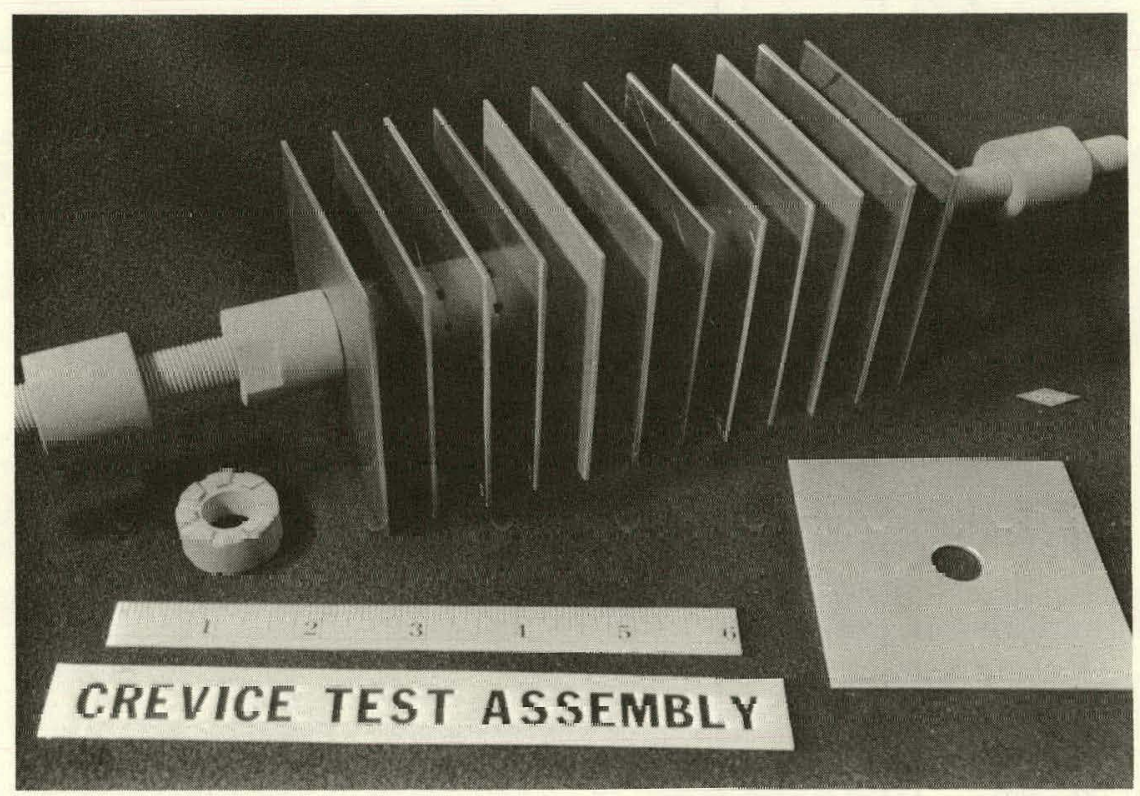

Figure III-7

CREVICE CORROSION SPECIMEN ASSEMBLY 
All specimens were prepared such that all edges have a 400 grit or better surface.finish, with all edge and center hole burrs removed. The coupon plate surface remained in a factoryreceived condition. For identification, all specimens were numbered in the lower right-hand corner using an electric scribe. Specimens were then degreased using Chlorothene ${ }^{\circledR}$ solvent in an ultrasonic cleaner for a minimum of five minutes. At this point, a portion of the aluminum alloy 5052 specimens were pretreated in slowly boiling deionized water for eight hours. The specimens were stored in a desiccator prior to use and weighed just prior to insertion into the test environment.

Upon removal from the test environment, photographs were made of the fouled/scaled specimens, thickness of the scale determined, and specimens submitted for analysis of surface deposits. Specimens were then acid-cleaned using an ultrasonic cleaner to reduce specimen exposure time to the acid solution. Solutions and times are indicated below:

\begin{tabular}{lrr}
\multicolumn{1}{c}{ Metal } & \multicolumn{1}{c}{ Solution } & Time Exposed \\
CP titanium & $238 \mathrm{HNO}_{3}\left(25^{\circ} \mathrm{C}\right)$ & $5 \mathrm{~min}$. \\
Aluminum alloys & $28 \mathrm{CrO}_{3}, 5 \mathrm{H}_{3} \mathrm{PO}_{4}$ & $30 \mathrm{~min}$. \\
& Sol'n. $\left(70^{\circ} \mathrm{C}\right)$ &
\end{tabular}

Specimen blanks were similarly cleaned to determine the extent of the cleaning loss.

After acid cleaning, specimens were degreased and weighed. Weight losses were determined for calculation of general corrosion rates.

3. Data Resolution

Weight loss and microscopic data was resolved into average penetration, final interval corrosion rate, maximum pit depth, and approximate pit deneity.

In order to facilitate data usage by the OTEC community, corrosion was expressed as corrosion penetration for the given period of exposure. This was calculated in the following manner:

$$
\text { (Metal Penetration })=\frac{(\text { Specimen Weight Loss) }}{(\text { Specimen Area) (Metal Density) }}
$$

Data is commonly expressed in mils (mm.) penetration. However, passivating alloys often experience a high initial penetration which is not indicative of long-term alloy performance, as indicated in Figure III-8. Thus, corrosion rate assessment of long-term performance of passivating alloys is often more accurately represented by the "final interval" corrosion rate, or the time and penetration difference 
Figure III-8

ALLOY COF.ROSION PERFORMANCE

PENETFATION VS. TIME

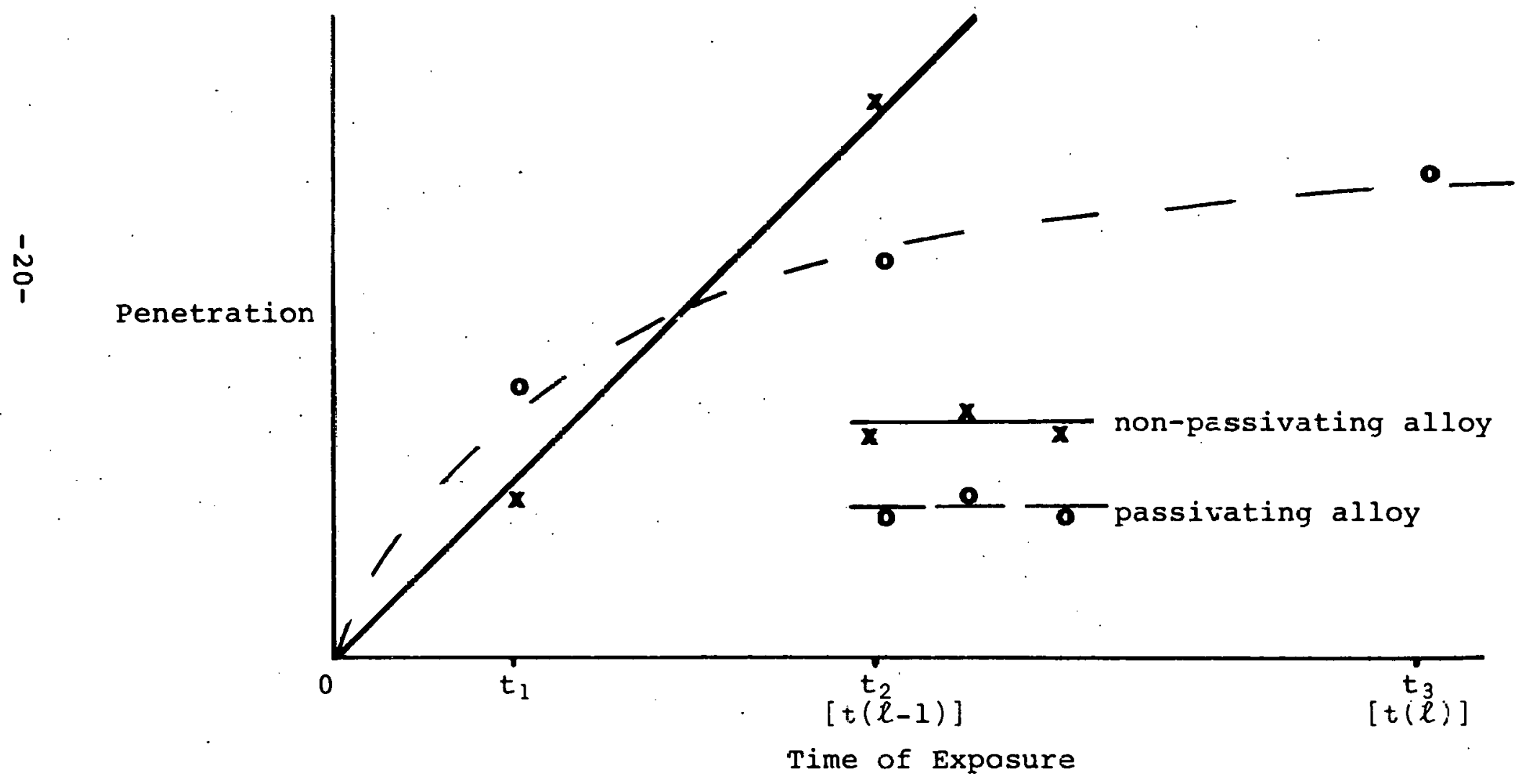


generated using the final two specimen pulls. The final interval corrosion rate (FICR) was calculated in the following manner:

$$
\text { FICR }=\frac{\text { Penetration }\left(t_{l}\right)-\text { Penetration }\left(t_{\ell-1}\right)}{\left(t_{\ell}\right)-\left(t_{l-1}\right)}
$$

where

$\left(t_{\ell}\right) \equiv$ Time of exposure for last specimen pulled

$\left(t_{\ell}-1\right) \equiv$ Time of exposure for next to last specimen pulled and Penetration $(t) \equiv$ Penetration at time " $t$ "

Data for the extrapolated final interval corrosion rate is expressed in terms of mpy (mm/yr.).

Pit and crevice attack was assessed using the following general format:

Incipient pitting: Pits less than 0.5 mils deep, discernable as pits under $25 x$ magnification.

Small pits: Pits 1.0-0.5 mils deep, discernable as pits under 10x magnification and visible to naked eye.

Pits: Pits 1-2 mils deep (unless otherwise indicated), readily visible as pits to naked eye.

Very Few: Less than 5/sq.in.

Few: $5-10 / \mathrm{sq}$.in.

Several: $10-15 / \mathrm{sq}$. in.

Numerous: More than 15/sq.in.

This format was developed to assess observations from the limited surface area exposed. Each specimen was completely examined under $10 \mathrm{x}$ magnification to generate the required information: Pits greater than $0.50 \mathrm{~mm}$ (2 mils) deep were measured using an Ames depth gauge (No. 11B-202P).

\section{Special Considerations: Cleaning Test}

The purpose of this test is to compare the influence on corrosion of mechanical and chemical techniques. Further, it is desired that the cleaning. technique remove surface deposits and growth but not disturb the passive surface film. The selection of cleaning techniques used in these very preliminary tests should not be inferred as a choice of the superior cleaning method available.

Handling of these specimens before exposure is as outlined in the previous section. Under test, these specimens were exposed to unfiltered seawater free of debris and macroscopic marine life. Then at periods of $1,3,5$, and 10 months the specimens were removed for test purposes. 
The mechanical cleaning technique employed consisted of a simulated M.A.N. ${ }^{\circledR}$ brush system. Four test tube brushes were mounted parallel so that, when viewed from the brush ends, a square was formed, $1-3 / 8$ inches to a side as measured centerto-center on the brushes. Specimen cleaning consisted of six highly oscillating passes through the brushes ( $25 \%$ brush compression) in a direction perpendicular to the mounted brushes. Cleaning was performed under flowing tap water. A schematic of this apparatus is shown in Figure III-9.

Chemical cleaning chosen utilized a non-proprietary mix that can be foamed. Four chemical solutions were screened for application in this test:

1. Mild - 1/2\% wt. (maximum) hydrogen peroxide in deion water for 12 hours at ambient temperature. Deion water rinse.

2. Mild - 5\% wt. sodium hypochlorite in deion water; $\overline{0.5 \%}$ wt. sodium metasilicate; 12 hours at ambient temperature. Deion water rinse.

3. Alkaline - 5\% wt. sodium carbonate in deion water; 5\% wt. monosodium phosphate; 5\% wt. trisodium phosphate; $0.5 \%$ wt. sodium metasilicate; 12 hours at ambient temperature. Deion water rinse.

4. Harsh-acid - $10 \%$ vol. conc. $\mathrm{H}_{2} \mathrm{SO}_{4}$ in deion water; 2\% wt. chromic acid; 4 hours at ambient temperature. Deion water in rinse.

of the solutions screened, the harsh acid cleaning solution provided the best results, based upon observed cleaning ability and solution corrosivity. Results of the screening tests are presented in Appendix A, Table IX-37. Specimens used in the tests were severely fouled aluminum alloy 3003-H14.

Upon sequential removal from the test environment, designated specimen groups were cleaned as indicated, photographed, observed, and reinserted in the test environment. In addition. to specimens for sequential chemical and mechanical cleaning, a set of specimens was installed which were not cleaned until the conclusion of the test. After the 10-month observations were concluded, all specimens were ultrasonically acid cleaned, as described in section IV-B, degreased, and weighed. Corrosion calculations and inspections were then performed, and a final photograph record of the specimen condition made. 
Figure III-9

BRUSH ARRANGEMENT USED FOR MECHANICAL CLEANING

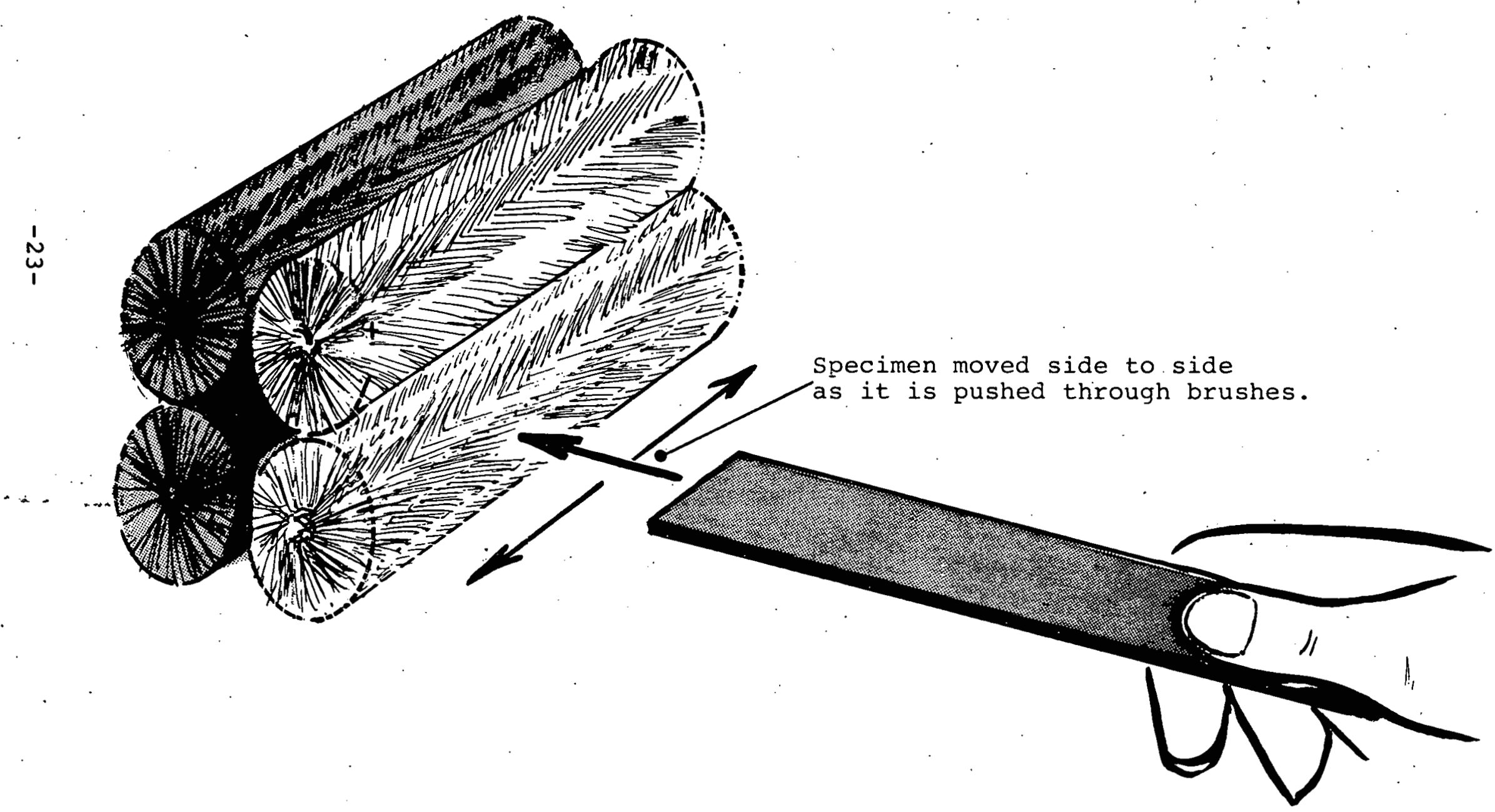


Ammonia in recirculating seawater tests were performed at both $5^{\circ} \mathrm{C}$ and $30^{\circ} \mathrm{C}$ to simulate OTEC condenser and evaporator temperature regimes. Leakage severity was tested by forming nominal ammonia concentration levels in the seawater of 8 , 30,80 , and $800 \mathrm{ppm}$ at the two temperatures. In addition, ambient temperature seawater controls were run in parallel with the 8,30 , and $800 \mathrm{ppm}$ ammonia in seawater tests to assess the corresponding influences of seawater corrosion and fouling behavior. Relevant information sought consisted of fouling formation and corrosion performance of the subject alloys.

\section{A. Scale Formation.}

Mixing of ammonia and water will result in hydrolysis of the ammonia to form ammonium and hydroxyl ions. The resulting solution is thus more alkaline, and in seawater an increase in alkalinity enhances calcium carbonate and magnesium hydroxide precipitate formation. Precipitates so formed may then nucleate and form scales on heat exchanger surfaces in a manner which will seriously impair heat transfer.

This set of problems is due to the nature of the hydrolysis of ammonia and to the formation of hydroxyl ion:

$$
\mathrm{NH}_{3}{ }^{0}+\mathrm{HOH} \rightarrow \mathrm{NH}_{4}^{+}+\mathrm{OH}^{-}
$$

As a result of the hydroxyl ion formation, solutions of ammonia in water are very basic. Then, the hydroxyl ion in seawater reacte with bicarbonate (Llie pieluminn!lt 1onic form of carbon dioxide) to produce carbonate ion:

$$
\mathrm{HCO}_{3}^{-}+\mathrm{OH}^{-} \rightarrow \mathrm{CO}_{3}=+\mathrm{HOH}
$$

which in turn will react with calcium present to precipitate calcium carbonate:

$$
\mathrm{Ca}^{++}+\mathrm{CO}_{3}=, \mathrm{CaCO}_{3} \psi
$$

or, alternately, the hydroxyl ion produced by the hydrolysis of ammonia can react dirertly with the magnesium prcscnt in seawater to precipitate magnesium hydroxide:

$$
\mathrm{Mg}^{++}+2 \mathrm{OH}^{-} \rightarrow \mathrm{Mg}(\mathrm{OH})_{2} \downarrow
$$

In general, if sufficient ammonia is present, the sequence of chemical events would be:

$$
\begin{aligned}
& \text { 1. conversion of } \mathrm{HCO}_{3}-\text { to } \mathrm{CO}_{3}= \\
& \text { 2. precipitation of } \mathrm{CaCO}_{3} \\
& \text { 3. precipitation of } \mathrm{Mg}(\mathrm{OH})_{2} \\
& \text { 4. elevation of solution } \mathrm{pH}
\end{aligned}
$$


In these tests ammonia was added to the recirculating seawater loop (with continuous refreshment) as ammonium hydroxide, ammonia already hydrolized to its product ions. Levels of addition were as previously stated. The results, summarized in Figure IV-1, indicate greater rates of scale/fouling growth at higher temperatures and concentrations of ammonia. Figure IV-2 is presented to indicate the corresponding increase in $\mathrm{pH}$. Not indicated is a slight difference observed in initial scale nucleation rates for the subject alloys, in which CP titanium and pretreated aluminum alloy 5052-H14 were observed to very slightly retard initial scale growth.

Crystalline components of the scale were determined using $x-r a y$ diffraction, energy dispersive $\mathrm{X}$-ray, and infrared spectral analysis. Scale composition development followed the pattern shown in Figure VI-3, with calcite forming initially followed by aragonite and brucite at higher ammonia concentrations and temperatures. At zero and $8 \mathrm{ppm}$ ammonia in seawater primary constituents of the surface deposit are amorphous muds and organics.

Observations indicated that fouling/scale formation may be controllable at $8 \mathrm{ppm}$ ammonia in seawater, $5^{\circ} \mathrm{C}$ and $30^{\circ} \mathrm{C}$, and $30 \mathrm{ppm}$ ammonia in seawater, $5^{\circ} \mathrm{C}$, if a continuous cleaning process is employed. It is believed, however, that concentrations of ammonia in seawater above $80 \mathrm{ppm}$ would not be economically controllable. of the subject alloys tested, fouling appeared to be more easily removed from $\dot{C} P$ titanium and pretreated aluminum alloy 5052-HI4. Figure IV-4 shows the scale at 10 days for the 800 ppm exposure.

\section{B. Corrosion}

Experience with the use of aluminum has indicated that this metal can be sensitive to pit attack in alkaline media. As seawater is slightly alkaline, and seawater plus ammonia is more alkaline, it was necessary to perform preliminary screening tests to evaluate specified aluminum alloys under environmental conditions as close as possible to conditions which may be encountered in an OTEC heat exchanger. Titanium, another contender for OTEC heat exchanger use, was also tested. Information sought in these coupon scale tests is final interval corrosion rate*, maximum pit penetration, and crevice attack. The resolved data for the subject alloys is summarized in Figures IV-5 and IV-6.

* "Final Interval" corrosion rate is a predicted long-term corrosion rate which the metal should experience after the surface has become passivated from continued exposure. The methodology involved in calculating this rate is given in Section III.C.3, "Data Resolution". 
FIGURE IV-1

FOLLING FORMATION *

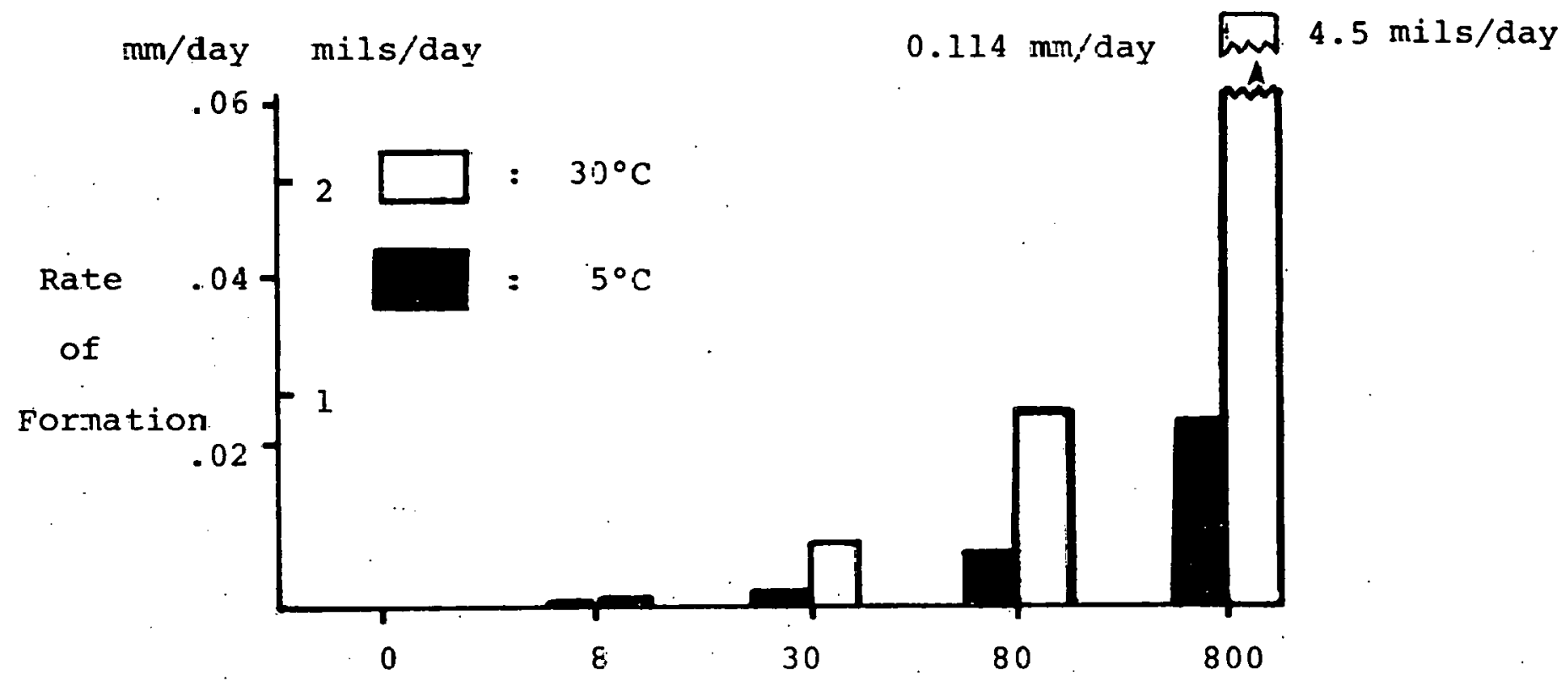

* As formed ori

Crevice Test Assbembly Ammoria Concentration (ppm) ( $0.26 \mathrm{fps}$ ) 
FIGURE IV-2

AMMONIA CONCENTRATION VS $\mathrm{pH}$

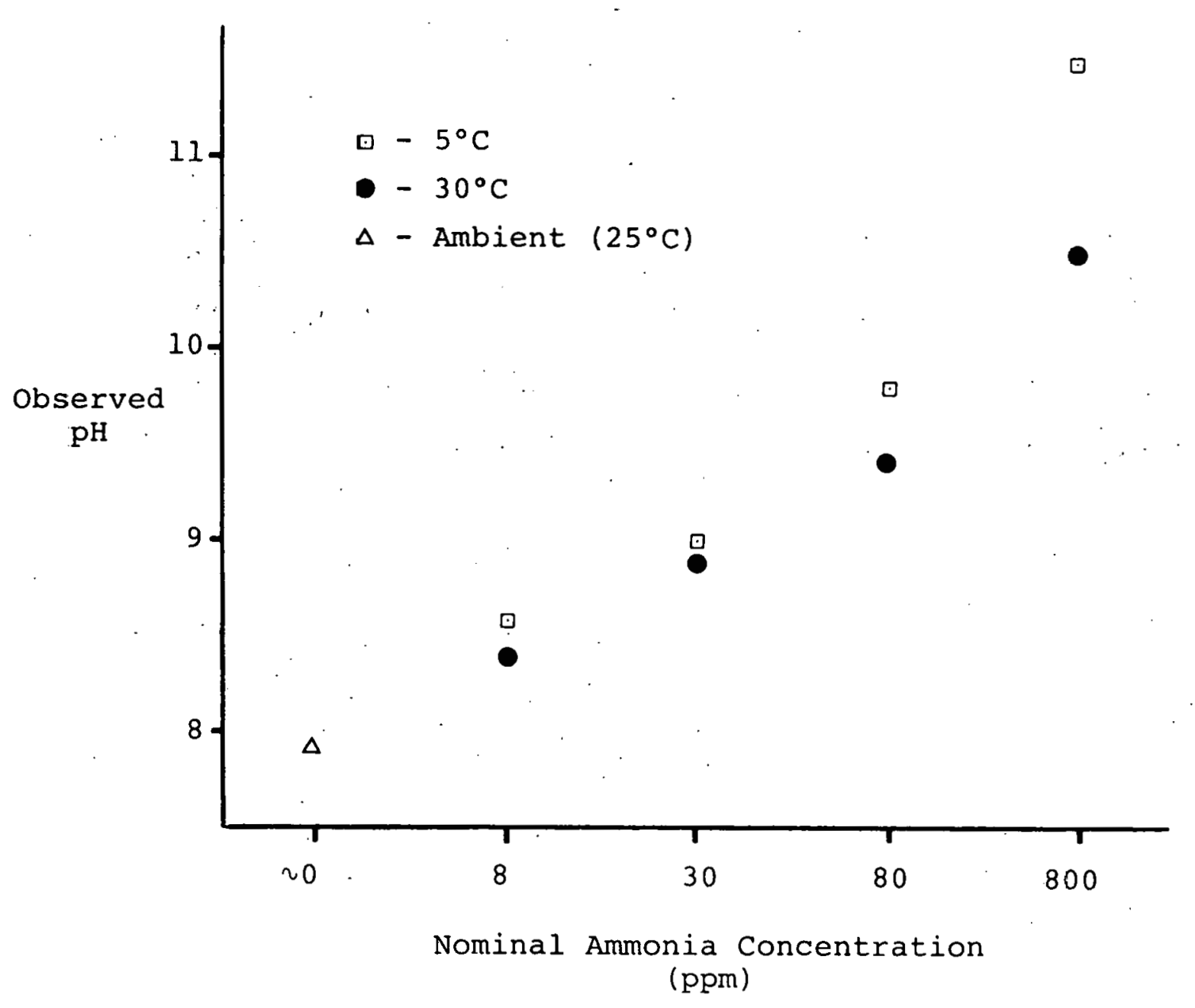


FIGURE IV-3

SCPLE COMPOSITION $\&$

FORMATION

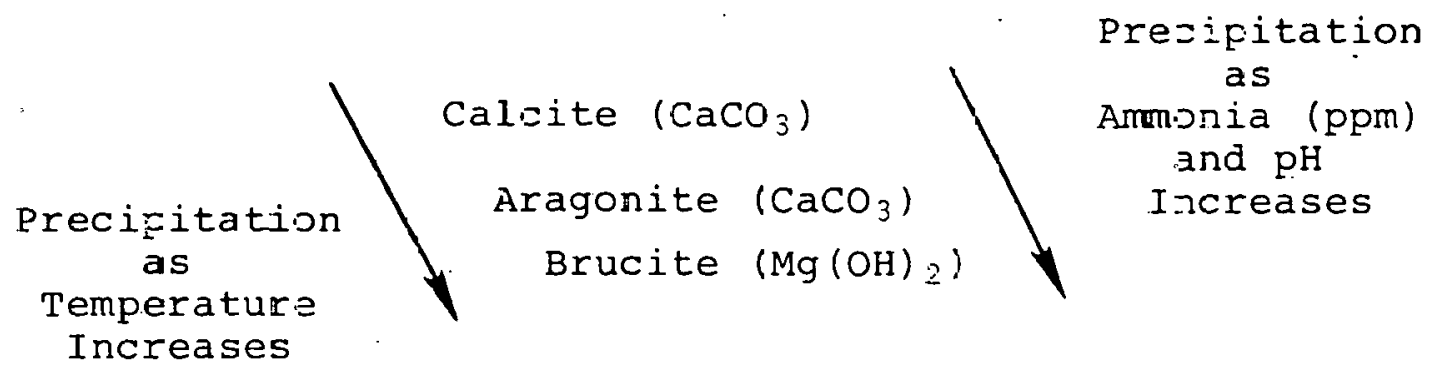




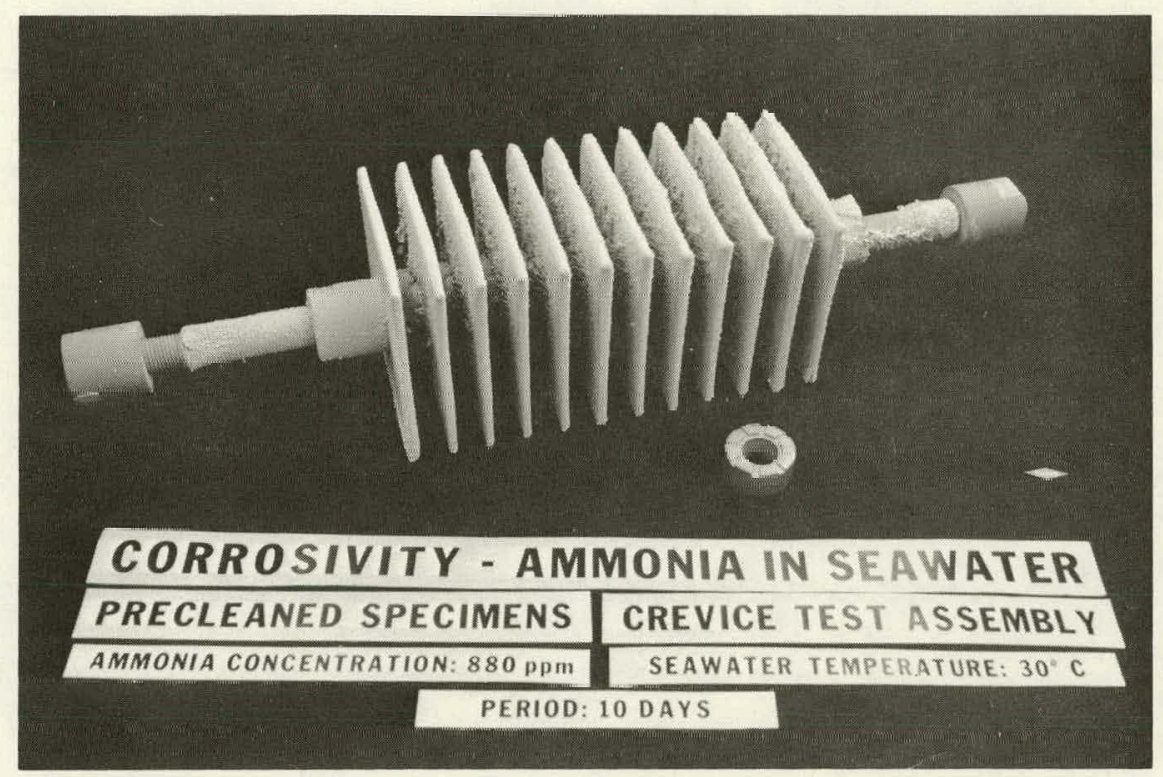

Figure IV-4

SCALE FORMATION ON CREVICE TEST ASSEMBLY $880 \mathrm{pPm}$ AMMONIA IN SEAWATER AT $30^{\circ} \mathrm{C}$ 
THIS PAGE

\section{WAS INTENTIONALLY LEFT BLANK}


FIGURE IV-6

CORROSION SUMMARY: FINAL INTERVAL CORROSION RATE ${ }^{-1}$ AND MAXIMUM PIT DEPTH SEAWATER MIXED WITH AMMONIA 2

CONDENSER: $5^{\circ} \mathrm{C}$

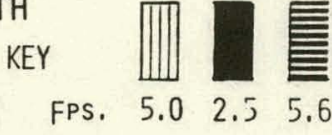

AL $3003-H 14$

AL 5052-H32

AL 5086-H32

AL $5052-H 32$ (TREATED)
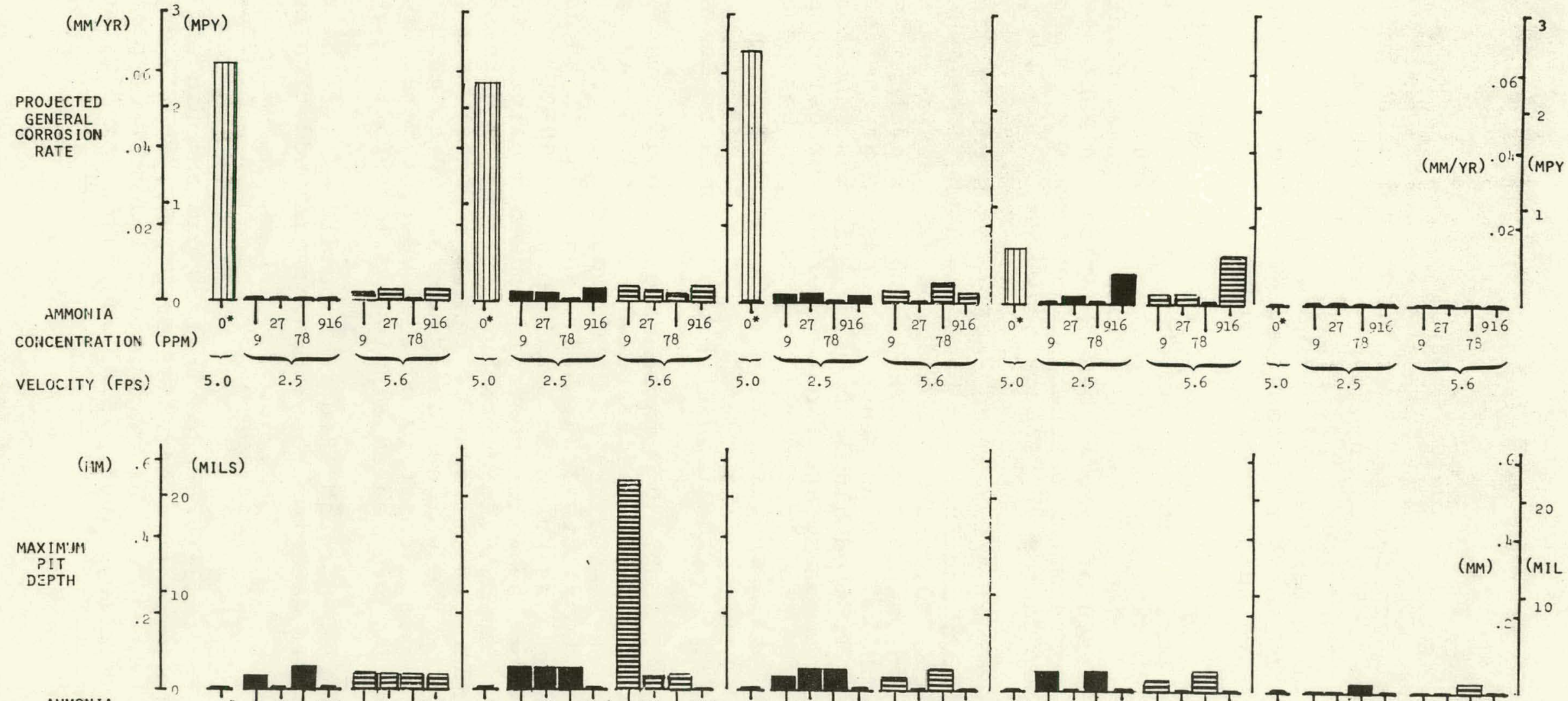

AM:MON IA
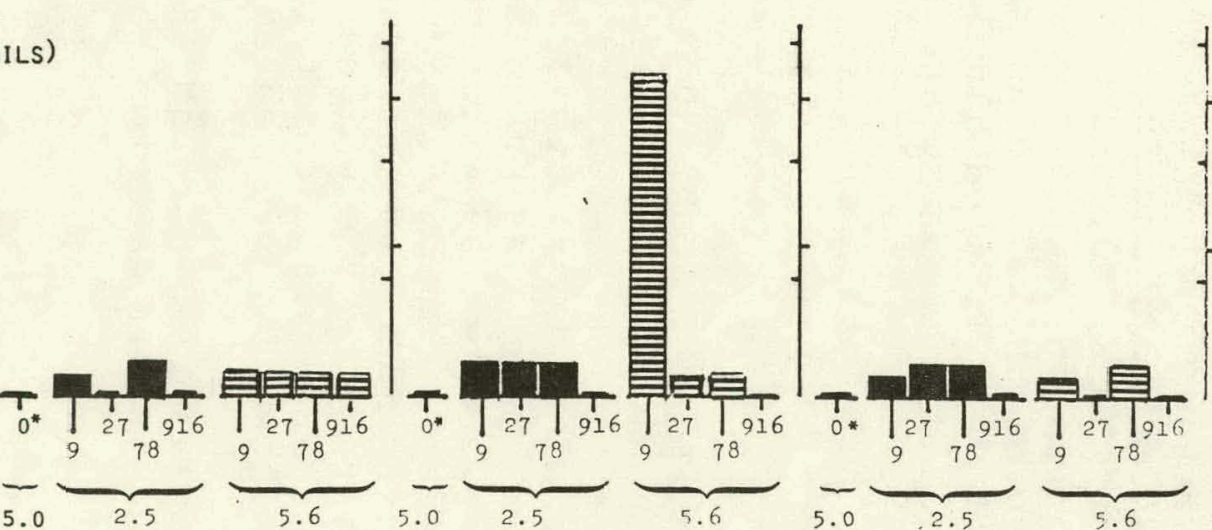
CONCENTRATION: (PPM) VELOCITY (FPS)
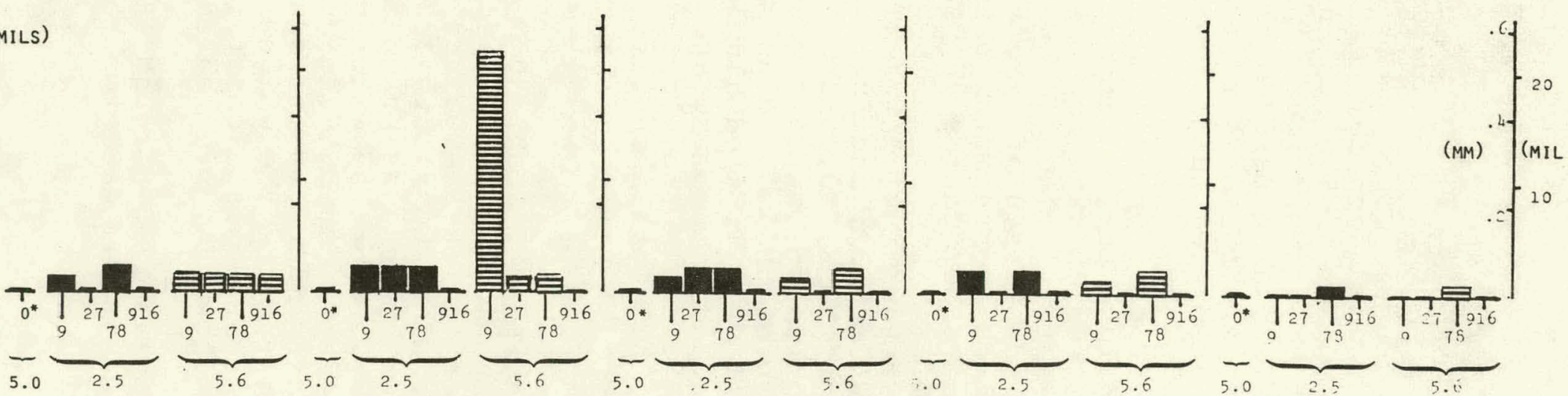

1 Final interval corrosion rate definition and calculation is discussed in Section ili.C.j, "Data ?esolution."

2 Includes amibient temperature controls $\left(223^{\circ} \mathrm{C}\right)$ - ilean value from table I $K-1$ 


\section{Seawater Controls}

Corrosion control tests were conducted using ambient temperature seawater at $5.0 \mathrm{fps}$ in a once-through system. Seawater temperature was previously presented in Figure III-4. Control tests were run at periods coinciding with the 8,30 , and $800 \mathrm{ppm}$ ammonia in seawater exposures. Detailed data for these tests is reported in Tables IV-I and IX-1.

Corrosion on the seawater controls was marked by general, uniform surface attack and the absence of significant pitting. Corrosion rate for the untreated aluminum alloys was significantly influenced by the seawater temperature at test initiatinn. A comparison of like exposure periods in Table IV-1 indicates direct correlation between higher seawater temperature and increased corrosion penetration.

Average final interval corrosion rates for aluminum alloys 3003, 5052, and 5086, as based upon the final specimen pulls for the 8,30 , and 800 ppm ammonia in seawater, seawater corrosion controls was 2.2-2.6 mpy, with aluminum alloy 5086 giving the most consistent performance of the three untreated alloys. Treated aluminum alloy 5052 was superior to all aluminum tested with a average final interval corrosion rate of $0.60 \mathrm{mpy}$. $\mathrm{CP}$ titanium showed negligible attack and was generally superior to all metals on test.

\section{Addition of $8 \mathrm{ppm}$ Ammonia to Seawater}

Tests at $5^{\circ} \mathrm{C}$ and $30^{\circ} \mathrm{C}$ in seawater with a nominal 8 ppm added anmunid were completed after 8, 29, and 64 day specimen pulls. For the test exposure at $30^{\circ} \mathrm{C}$, aggressive pit attack was noted on aluminum alloys 3003, 5052, and 5086. Also, at $5^{\circ} \mathrm{C}$, aggressive pit attack was noted on aluminum alloy 5052. Parallel ambient temperature seawater controls showed greater average corrosion penetration but insignificant pit attack on these same alloys. performance of the crevice test specimens was generally superior to that of the weight loss coupons. CP titanium showed negligible. pit attack and constituted the superior metal at these exposures followed by pretreated aluminum alloy 5052 .

'l'ables $1 \mathrm{X}-2$ Lhrouyh IX-6 in Appendix A list the corrosion and analytical data for the $8 \mathrm{ppm}$ ammonia addition tests.

\section{Addition of $30 \mathrm{ppm}$ Ammonia to Seawater}

Exposures utilizing a nominal $30 \mathrm{ppm}$ ammonia addition at $5^{\circ} \mathrm{C}$ and $30^{\circ} \mathrm{C}$ were terminated after 14,30 , and 59 day specimen pulls. At $30^{\circ} \mathrm{C}$, one or two pits $1-2$ mils deep were noted on aluminum alloys 3003,5052 , and 5086 . At $5^{\circ} \mathrm{C}$, no significant 
Tabic IV-1

CORROSION DATA FOR TEST

Total Average Penetration (mils) of Ambient Temperature Seawater Controls

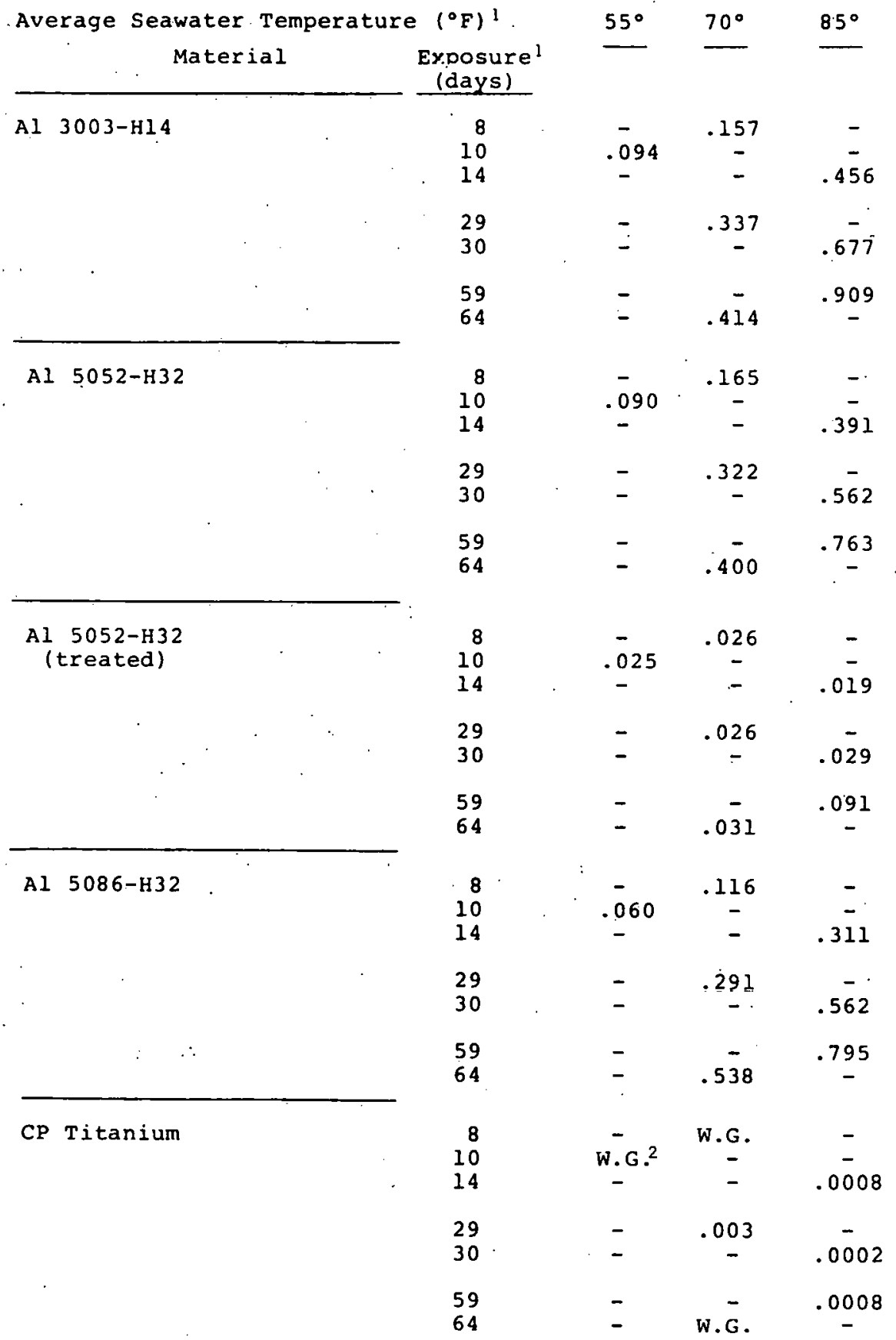

'Each pull of the $\mathrm{NH}_{3}$ in seawater corrosion test had a companion seawater control. This accounts for the variety of exposure time during the year.

Weight Gäin 
pit attack occurred. Crevice corrosion was not observed at the $30^{\circ} \mathrm{C}$ temperature exposure. At $5^{\circ} \mathrm{C}, \therefore 1-2$ mils crevice attack penetration was noted on aluminum alloys 3003,5052 , and 5086 . CP titanium gave the best corrosion performance of any metal tested at this exposure followed by pretreated aluminum alloy 5052 .

Tables IX-8 through IX-13 in Appdneix A list the corrosion and analytical data for the 30 ppm ammonia addition tests.

\section{Addition of 80 ppm Ammonia to Seawater}

Exposures at $5^{\circ} \mathrm{C}$ and $30^{\circ} \mathrm{C}$ were completed with pulls at 10,30 , and 51 days. The proposed 60 -day exposures were cut short. because of extensive calcareous scaling within the units. Final interval corrosion rates for the aluminum alloys at $30^{\circ} \mathrm{C}$ were generally 50-100\% of the average final interval corrosion rate of th ambient temperature seawater controls. Final interval corrosion rates at $5^{\circ} \mathrm{C}$ were minimal. Maximum observed pit depth on any specimen was estimated at less than 1 mil penetration. No significant crevice attack was noted on either test after 50 days although some slight impressions were present at the lower temperature. Again, CP titanium and pretreated aluminum alloy 5052 showed overall superior performance.

Tables IX-14 through IX-2l in Appendix A list the corrosion and analytical data for the $80 \mathrm{ppm}$ ammonia in seawater exposures.

$$
\text { 5. Addition of } 800 \mathrm{pmm} \text { Ammonia to Seawater }
$$

The $5^{\circ} \mathrm{C}$ and $30^{\circ} \mathrm{C}$ exposures at $800 \mathrm{ppm}$ ammonia in seawater were terminated at 10 days because of excessive scaling. Both final interval corrosion rates and pitting were negligible, a factor probably related to the rapid scaling.

Tables IX-22 through IX-27 in Appendix A list the corrosion and analytical data for the $800 \mathrm{ppm}$ ammonia in seawater exposure. 


\section{SEAWATER IN AMMONIA}

Seawater in ammonia tests were performed at $5^{\circ} \mathrm{C}$, the OTEC condenser temperature, and at addition severities of a nominal $0 *, 0.1,1.0$, and $2.5 \%$ seawater concentration. Analysis performed for each exposure included percent water by volumetric evaporation or barium oxide absorption, sodium ion concentration by atomic adsorption analysis, and chloride ion concentration by the Volhard method of analysis. Scale was not observed to form within the test unit over the range of seawater concentrations investigated. In addition to scaling possibilities, relevant information sought consisted of final interval corrosion rates, maximum pit depth, and crevice attack for the subject alloys. Pit and final interval corrosion rates for these test exposures are summarized in Figure $\mathrm{V}-1$.

\section{A. Anhydrous Ammonia}

Corrosion tests in $5^{\circ} \mathrm{C}$ commercially pure anhydrous ammonia (151 ppm water) were terminated after 10 and 38 day specimen exposures. Pit, crevice, and uniform corrosion attack were minimal on all alloys tested. Initial high penetrations

observed on pretreated aluminum alloy 5052 did not increase significiently for subsequent exposure periods, so that at the conclusion of the test all aluminum alloy penetrations were comparable. CP titanium demonstrated corrosion resistance superior to that of any metal tested, followed in order by pretreated aluminum alloy 5052 and aluminum alloys 5052, 3003 , and 5086.

Tables IX-28 through IX-30 in Appendix A list the corrosion and analytical data for this exposure.

\section{B. Anhydrous Ammonia plus 0.1\% Seawater}

Corrosion tests in $5^{\circ} \mathrm{C}$ anhydrous ammonia with $0.1 \%$ nominal seawater were terminated after 10 and 24 day exposure periods. Pitting and crevice attack was negligible for all alloys tested. Final interval corrosion rates for aluminum alloys 3003,5052 , and 5086 are less than $0.12 \mathrm{mpy}$ at $2.5 \mathrm{fps}$ and 0.43-0.69 mpy at 5.6 fps, thus indicating a significant velocity effect at this exposure. Initial high average corrosion penetrations for pretreated aluminum alloy 5052 give a final interval corrosion rate at 24 days which is negligible. The superior metals at this exposure are CP titanium and pretreated aluminum alloy 5052 .

Tables IX-28, 31, 32, and 33 summarize the corrosion and analytical data for this exposure.

* Measured water content $150 \mathrm{ppm}$. 
FIGURE $V$-I

CORROSION SUMMARY: FINAL INTERVAL CORROSION RATE ${ }^{1}$ AND MAXIMUM PIT DEFTH AMMONIA MIXED WITH SEAWATER

CONDENSER: $5^{\circ} \mathrm{C}$

\section{FPs.}

AL 3003-H14

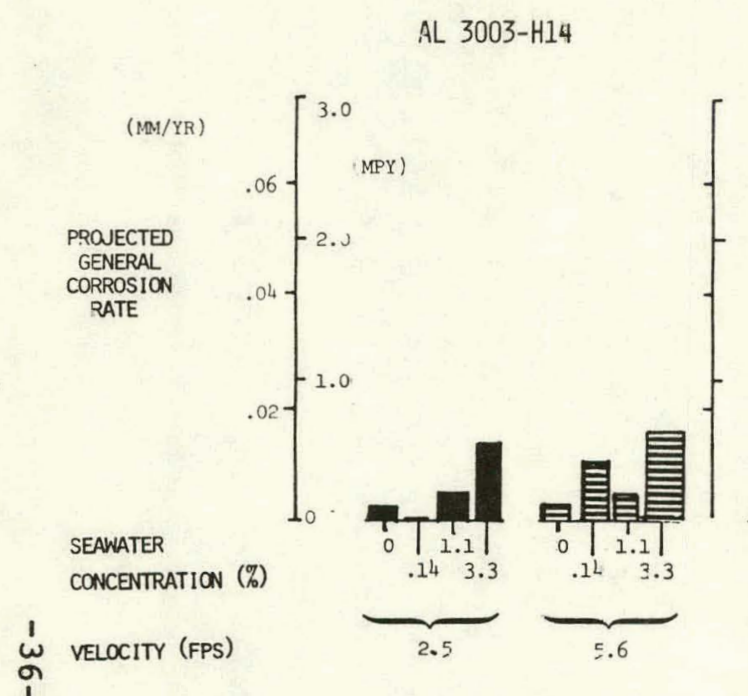

AL $5052-H 32$

AL $5036-H 32$
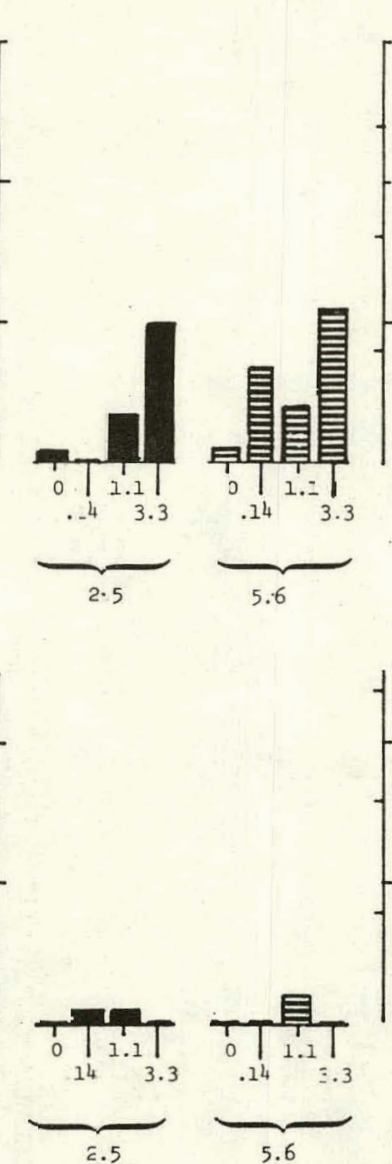
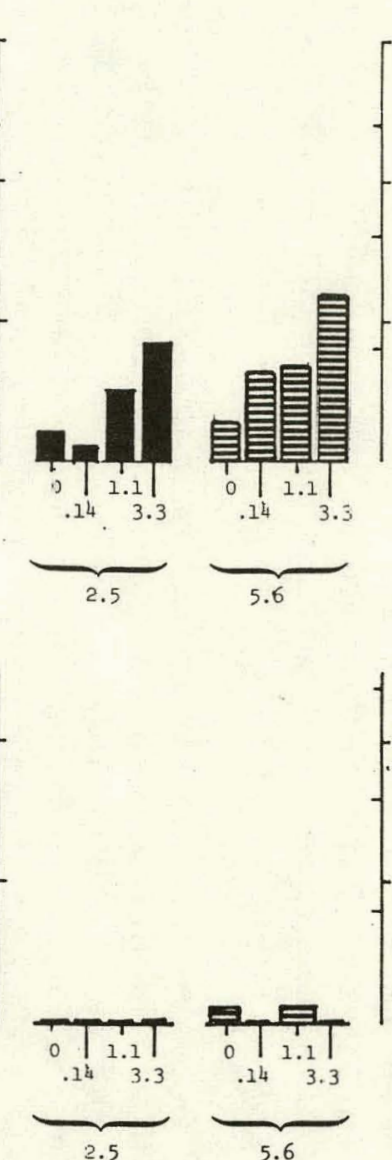

AL 5052-HZ2

(TREATEI)
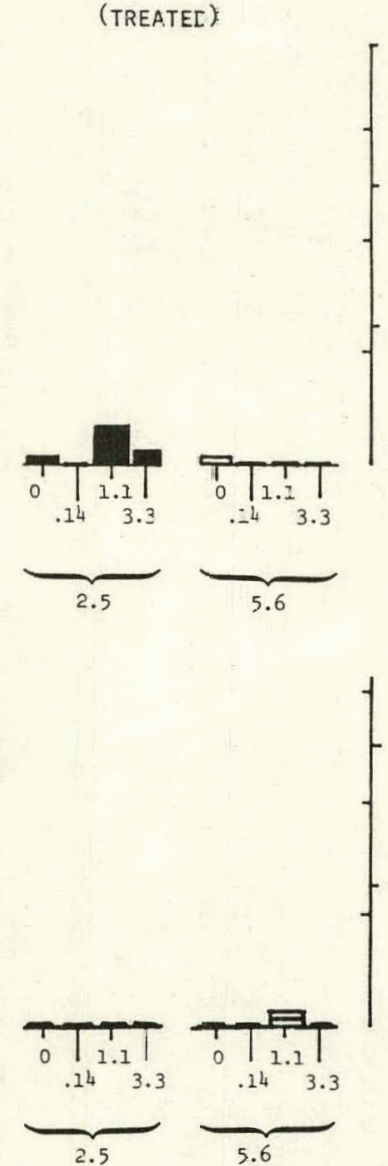

CP TITANIUH
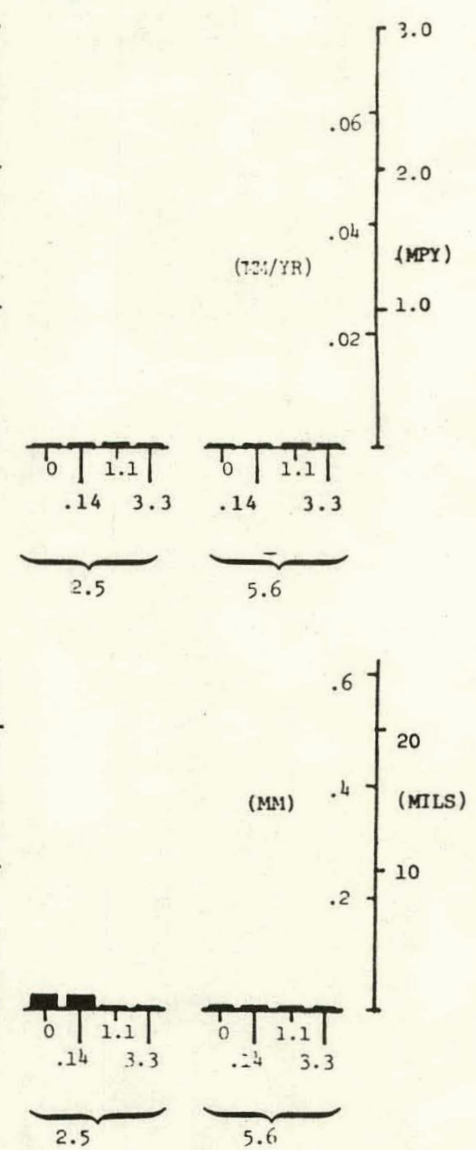

"Final interval corrosion rate is ciscussed in Section III,C.3, "Jata Reso ution." 
C. Anhydrous Ammonia plus $1.0 \%$ Seawater

Corrosion tests in $5^{\circ} \mathrm{C}$ anhydrous ammonia plus $1 \%$ nominal seawater were terminated after specimen exposure periods of 10, 28, and 59 days. Pitting and crevice attack was negligible except for one pit observed on aluminum alloy 5052 at 5.6 fps. Initial high corrosion penetrations on pretreated aluminum alloy 5052 did not continue to increase significiantly so that after 59 days this alloy showed negligible additional attack. . CP titanium constituted the superior metal at this exposure followed by pretreated aluminum alloy 5052 .

Tables IX-28, 34, and 35 in Appendix A list the corrosion and analytical data for this exposure.

\section{Anhydrous Ammonia plus 2.5\% Seawater}

Corrosion tests in $5^{\circ} \mathrm{C}$ anhydrous ammonia plus a nominal $2.5 \%$ seawater were terminated after 10, 30, and 53 day exposures. Pit and crevice attack were negligible at this exposure although final interval corrosion rates for aluminum alloys 3003, 5052, and 5086 were greater than for ammonia exposures with lower seawater percentages. Initial high penetrations on pretreated aluminum alloy 5052 did not continue to increase significantly through the 53-day exposure. CP titanium again constituted the superior metal for this exposure followed by pretreated aluminum alloy 5052 .

Tables XI-28,36, and 37 in Appendix A list the corrosion and analytical data for this exposure. 
VI. SPECIAL CLEANING TESTS

Cleaning test specimens were continuously exposed to ambient temperaure, unfiltered seawater for a total of 10 months with specimen cleaning pulls at $1,2,3$, and 7 months. Additionally, an extra set of specimens (Group 2) was entered and specimen cleaning pulls conducted at $1 \frac{1}{2}, 6$, and 9 month intervals. Mechanical (M.A.N. ${ }^{\circledR}$ Brush) and chemical (sulfuric/chromic acid) cleaning procedures were as previously outlined in the section "Specimen Procedures". In addition to these tests, a set of uncleaned corrosion control blanks were inserted in the test. At 10 months all specimens were ultrasonically acid cleaned to permit determination of specimen corrosion rate.

Neither the chemical or mechanical cleaning tests conducted were intended to be sufficlently comprehensive to suggest a cleaning system for use in an OTEC plant. More extensive tceting on a more continuous hasis is strongly suggested.

Results of this testing are summarized in Figure VI-l. Uncleaned corrosion control specimens gave the best corrosion performance, closely followed by specimens cleaned using the simulatcd M.A.N. ${ }^{\circledR}$ brush system. Film buildup on the uncleaned controls was severe, however, and it is believed that the resulting loss of heat transfer could not be tolerated in an OTEC plant. Further, corrosion rates which might be attributed to the daily use of a M.A.N. ${ }^{\circledR}$ brush system cannot accurately be extrapolated from these tests. However, based on these cursory results, a mechanical cleaning system is the preferred mechanism of fouling control for the aluminum alloys tested.

The performance of CP titanium was independent of cleaning techniques employed, showing overall excellent performance. Pretreated aluminum 5052 provided the lowest general corrosion rate of any aluminum alloy; however this material was subject to very severe pit attack under debris which would accumulate at the upstream specimen end. Severe pit attack was not noted on aluminum alloys 3003, 5052, and 5086, although very broad but shallow pit depressions would again occur at the upstreall specimen end. For the uncleaned corrosion controls, aluminum alloy 5086 was followed in corrosion performance by aluminum alloyc 5053 and 3003, although merhanically cleaned specimens of these same alloys gave almost identical corrosion rates. 
FIGURE VI-1

TOTAL AVERAGE PENETRATION vs. CLEANING METHOD*

Al $3003-\mathrm{H} 14$

Al $5052-\mathrm{H} 32$

Al $5086-\mathrm{H} 32$
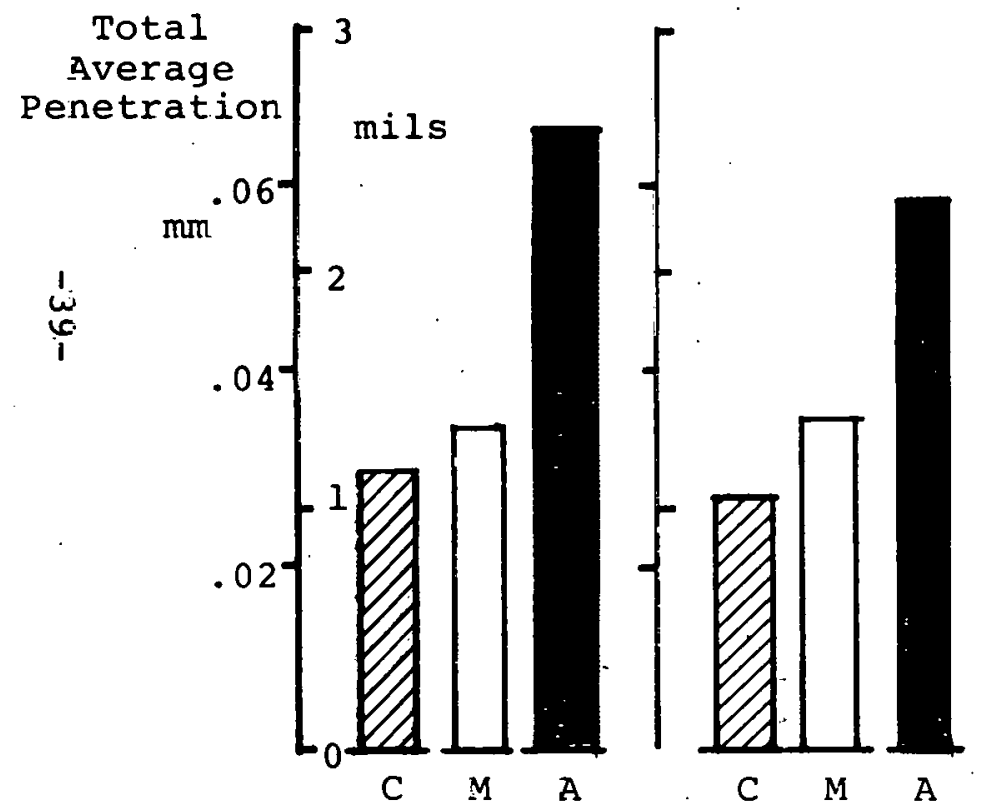

C $\mathrm{M} \quad \mathrm{A}$

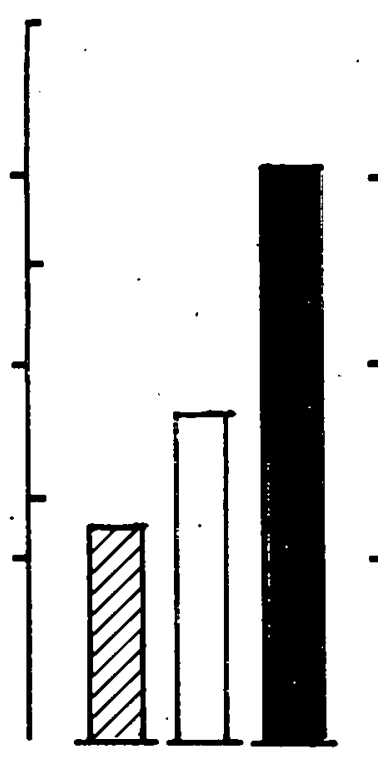

C M A
Al $5052-\mathrm{H} 32$ (treated)

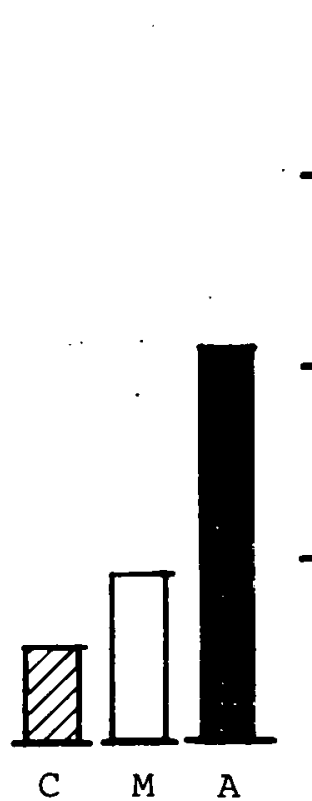

CP Titanium

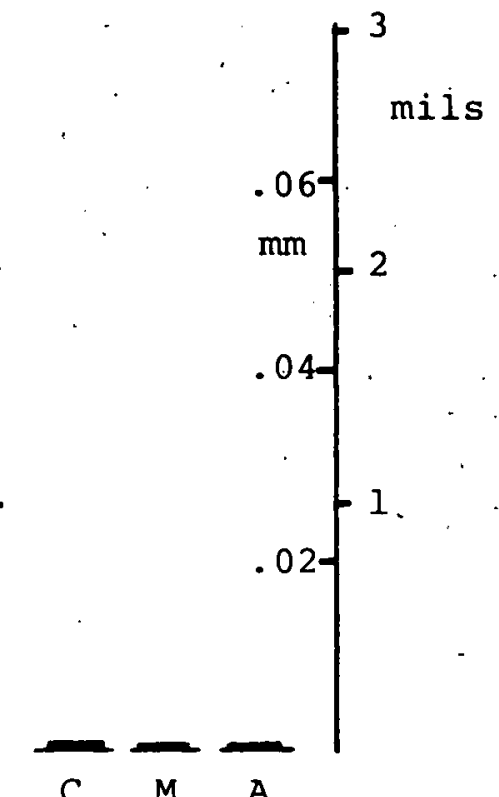

Cleaning Method:

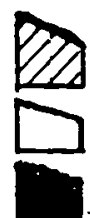

$C$ : Uncleaned Controls

M : Mechanical (MAN Brush)

A : Acid Chemical Cleaning
* Bar "C" is representative of a 10-month exposure without intermediate cleaning. Bars " $M$ " and " $A$ " represent 3-5 sequential cleaning experiences over 9-10 months. Final cleaning was standard laboratory practice. 
VII. RECOMMENDATIONS

1. Coupon tests are generally not designed to qualify specific materials for extended use application. These results indicate that further qualification tests of aluminum alloys for OTEC should proceed under a more rigorous environmental test simulation. Specifically, tubes should be tested with once-through flowing seawater having simulated ammonia leakage. Ultimately, full-scale mechanical cleaning equipment should be installed and employed.

2. In addition to aluminum alloys and $C P$ titanium, it is recommended that a chloride-resistant stainless steel and copper alloy 706 be included in further qualification testing. 


\section{BIBLIOGRAPHY}

1. Barkman, E. F. and R. I. Lindberg. "Aluminum Alloys for Use in Heat Exchanger Tubing for OTEC Applications", R. H. Gray (ed), Proceedings of the Ocean Thermal Energy Conversion (OTEC) Biofouling and Corrosion Symposium, National Technical Information Service, Springfield, Va. PNL-SA-7115, Oct. 1977. pp. 305-318.

2. Bonewitz, R. A. "Application of Aluminum Alloys", G. E. Ioup (ed), Proceedings Fourth Annual Conference On Ocean Thermal Energy Conversion, July 1977. pp. VI:37-40.

3. Bonewitz, R. A. "Corrosion of Aluminum in Ammonia-Water Mixtures", Aluminum Co. of America, Alcoa Center, Pa., March 1973.

4. Dow Chemical Co. "Seawater Corrosion Test Program, Part IV", for O.S.W., U.S. Dept. of the Interior, April 1975.

5. Fritsch, A., W. Adamson, and W. Castelli. "An Evaluation of Mechanical Cleaning Methods for Removal of Soft Fouling from Heat Exchanger Tubes in OTEC Power Plants", R. H. Gray. (ed), Proceedings of the Ocean Thermal Energy Conversion (OTEC) Biofouling and Corrosion Symposium, National Technical Information Service, Springfield, Va. PNL-SA-7115, Oct. 1977. pp. 159-166.

6. Griffin, O. M. "Power from the Oceans' Thermal Gradients", Sea Technology, Vol. 18, No. 8, August 1977. pp. 11-15, 38-39.

7. Laque, F. L. "Ocean Thermal Energy Conversion Corrosion Problems and Possible Solutions", R. H. Gray (ed), Proceedings of the Ocean Thermal Energy Conversion (OTEC) Biofouling and Corrosion Symposium, National Technical Information Service, Springfield, Va. PNL-SA-7115, Oct. 1977. pp. 209-222.

8. McIlhenny, W. F. "Chapter 21: Extraction of Economic Inorganic Materials from Seawater", Riley and Skirrow (eds), Chemical Oceanography, 2nd Ed., Vol. 4, Academic Press, New York, 1975. pp. 155-218.

9. National Association of Corrosion Engineers. "Laboratory Corrosion Testing of Metals for the Process Industries", N.A.C.E., Katy, Tex. NACE Standard TM-01-69 (Revised 1972).

10. Perrigo, L. D., and G. A. Jensen. "Ocean Thermal Energy Conversion System Biofouling and Corrosion Problems", Battelle Pacific Northwest Laboratories, Seattle, Wash. No. BNWL-SA-5970, Sept. 1976.

11. Uhlig, H. H. Corrosion and Corrosion Control, John Wiley \& Sons, Inc., New York, 1971.

12. York, J. L., and B. J. Schorle. and Prevention", K. S. Spiegler (ed), Principles of Desalination,

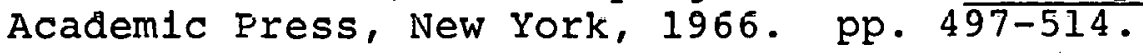


Appendix A

Detailed Tabular Data 
TABLE IX-1

FINAL INTERVAL CORROSION RATE (mPY) ${ }^{1}$ FOR AMBIENT TEMPERATURE SEAWATER CONTROLS

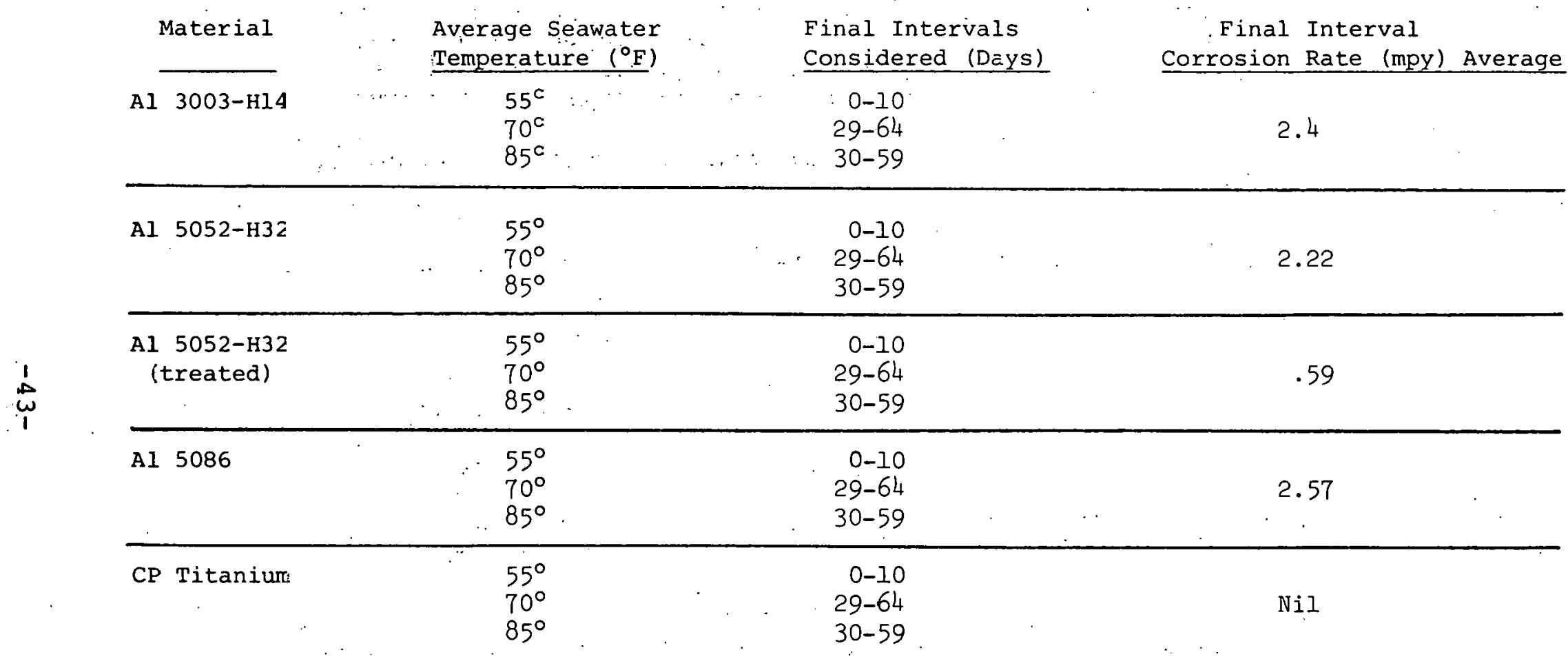

1 "Final Interval" corrosion rate is a predicted long-term corrosion rate which the metal should experience after the surface has become passivated from continued exposure. The methodology involved ir calculating this rate is given in Section III.C.3, "Data Resolution." 
TABLE IY -2

FINAL INTERVAL CORROSION RATES (mPY) $1-2$ IOR TEST EXPOSURES OE 8.0 PPM AMMONIA IN SEAWATER

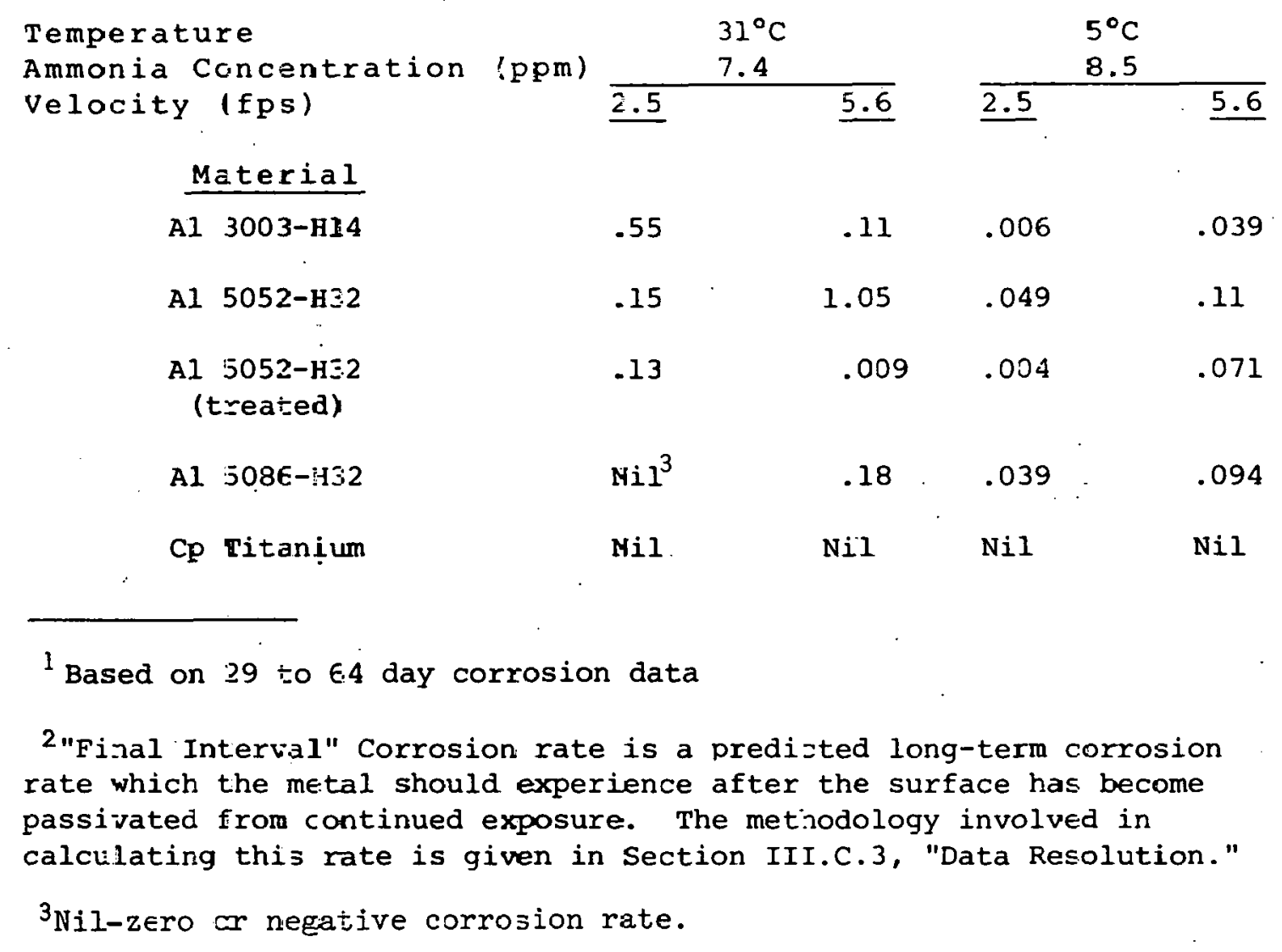


TABLE IX-3

TOTAL AVERAGE PENETRATION (mils) FOR TEST EXPOSURES OF 3.0 PPM AMMONIA IN SEAWATER

\begin{tabular}{|c|c|c|c|c|c|c|c|}
\hline $\begin{array}{l}\text { Temperature } \\
\text { Ammonia Conce }\end{array}$ & ation (ppm) & & ${ }^{\circ} \mathrm{C}$ & & & & \\
\hline Velocity (fee & er sec.j & Crevice & 2.5 & 5.6 & Crevice & 2.5 & 5.6 \\
\hline Material & $\begin{array}{c}\text { Exposure } \\
\text { (days) }\end{array}$ & & & & & & \\
\hline Al 3003-H14 & $\begin{array}{r}8 \\
29 \\
64\end{array}$ & $\begin{array}{l}-- \\
-\overline{0} \\
.033\end{array}$ & $\begin{array}{l}.057 \\
.068 \\
.120\end{array}$ & $\begin{array}{r}.085 \\
.108 \\
.119\end{array}$ & $\begin{array}{l}-- \\
-- \\
.047\end{array}$ & $\begin{array}{l}.068 \\
.081 \\
.082\end{array}$ & $\begin{array}{l}.077 \\
.087 \\
.091\end{array}$ \\
\hline Al $5052-\mathrm{H} 32$ & $\begin{array}{r}8 \\
29 \\
64\end{array}$ & $\begin{array}{c}-- \\
-\overline{-} \\
.031\end{array}$ & $\begin{array}{l}.092 \\
.075 \\
.089\end{array}$ & $\begin{array}{r}.148 \\
.122 \\
.223\end{array}$ & $\begin{array}{c}-- \\
-- \\
.052\end{array}$ & $\begin{array}{l}.070 \\
.079 \\
.084\end{array}$ & $\begin{array}{l}.079 \\
.087 \\
.098\end{array}$ \\
\hline $\begin{array}{c}\text { Al } 5052-\mathrm{H} 32 \\
\text { (Treated) }\end{array}$ & $\begin{array}{r}8 \\
29 \\
64\end{array}$ & $\begin{array}{l}-- \\
. \overline{021}\end{array}$ & $\begin{array}{l}.026 \\
.013 \\
.026\end{array}$ & $\begin{array}{l}.024 \\
.025 \\
.026\end{array}$ & $\begin{array}{l}-- \\
-\overline{-} \\
.017\end{array}$ & $\begin{array}{l}.025 \\
.020 \\
.021\end{array}$ & $\begin{array}{l}.029 \\
.023 \\
.030\end{array}$ \\
\hline A1 5086-H32 & $\begin{array}{r}8 \\
29 \\
64\end{array}$ & $\begin{array}{l}-- \\
. \overline{040}\end{array}$ & $\begin{array}{l}.102 \\
.131 \\
.100\end{array}$ & $\begin{array}{r}.110 \\
.123 \\
.142\end{array}$ & $\begin{array}{l}-- \\
-\overline{142}\end{array}$ & $\begin{array}{l}.068 \\
.078 \\
.082\end{array}$ & $\begin{array}{l}.084 \\
.087 \\
.096\end{array}$ \\
\hline CP Titanium & $\begin{array}{r}8 \\
29 \\
64\end{array}$ & $\begin{array}{l}-- \\
. \overline{-} \\
.0002\end{array}$ & $\begin{array}{l}\text { W.G. }{ }^{1} \\
\text { W.G. } \\
\text { W.G. }\end{array}$ & $\begin{array}{l}\text { W.G. } \\
\text { W.G. } \\
\text { W.G. }\end{array}$ & $\begin{array}{l}-- \\
-- \\
.0002\end{array}$ & $\begin{array}{l}\text { W. G. } \\
\text { W. G. } \\
\text { W. G. }\end{array}$ & $\begin{array}{l}\text { W.G. } \\
.002 \\
\text { W. G. }\end{array}$ \\
\hline
\end{tabular}

l W.G. signifies weight gain (zero penetration). 
TABLE IX -4

CORROSION DATA FOR TEST

$30^{\circ} \mathrm{C}$ SEAWATER + 7.5 PPM AMMONIA

Total Average Penetration (Mils) ${ }^{i}$ and (Max. Pit Depth, mils)

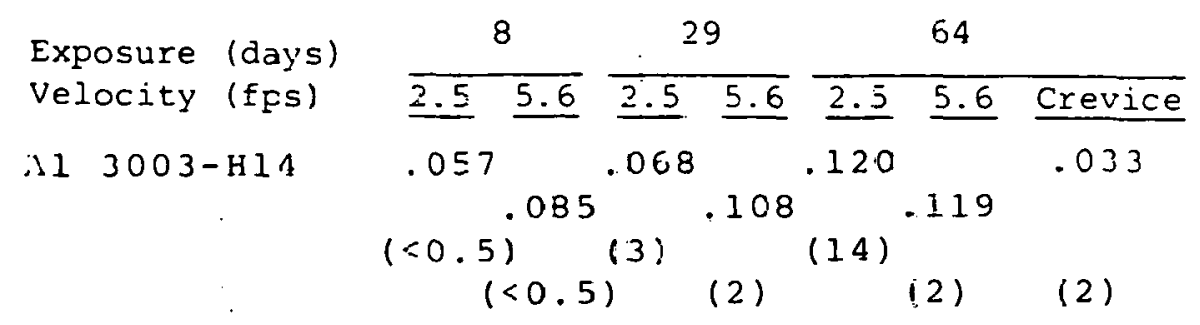

Pitting Observations ${ }^{2}$

At 2.j fps, a rery fulv incipient pits at $\varepsilon$ ciays, increasing to 1 pit, and 4 larger pits (up to $0.15 \mathrm{~cm}$ long and $3 \mathrm{mizs}$ deep) at 29 days, and at 64 days 1 pit $0.3 \mathrm{~cm}$ in diameter and $14 \mathrm{mils}$ deep.

At 5.6 fps, a very few incipient pits at 8 days, increasing to 2 pits up to $.15 \mathrm{~cm}$ long and 2 mils deep at 29 days, with 2 small pits and 2 pits observed at 64 days.

A very few incipient pits, 1 pit, and slight surface attack were noted at the crevice of the crevice specimen.

\begin{tabular}{lllllll}
\hline A1 5052-E.32 & .092 & .075 & & .089 & .031 \\
& $114)^{.148}$ & & .122 & & .223 & \\
& & $(15)$ & & (1) & $\left(21 \vdots^{\circ}\right.$ & (8)
\end{tabular}

At 2.5 fps, a few incipient pits at 8 days, 1 small pit, and 15 large fits with lengths up to $0.5 \mathrm{~cm}$ and depths to 14 mils. At 29 days, a very few incipient pits, 2 small Eits, and 1 pit $0.25 \mathrm{~cm}$ across and 10 mils deep were cbserved. At 64 days, a very few incipient öits, Z smili fits, and 9 harger pits lup to $1 \mathrm{~cm}$ lenatio ano il milc deepi sere observed.

At $5.6 \mathrm{fps}$, a very few incipient pits and 22 large pits (up to $0.7 \mathrm{~cm}$ long and $15 \mathrm{mils}$ deep) were observed, and at 64 days 1 small pit, 3 pits, and 1 pit $0.5 \mathrm{~cm}$ iong and $8 \mathrm{mils}$ deep were observed. On the crevice specimen, crevice attack 1-2 mils deep was noted at 4 locations under the artificial crevice. In addition, a very few incipient pits, 3 small pits, and 1 pit were observed over the specimen surface. 
Table IX-4 (continued)

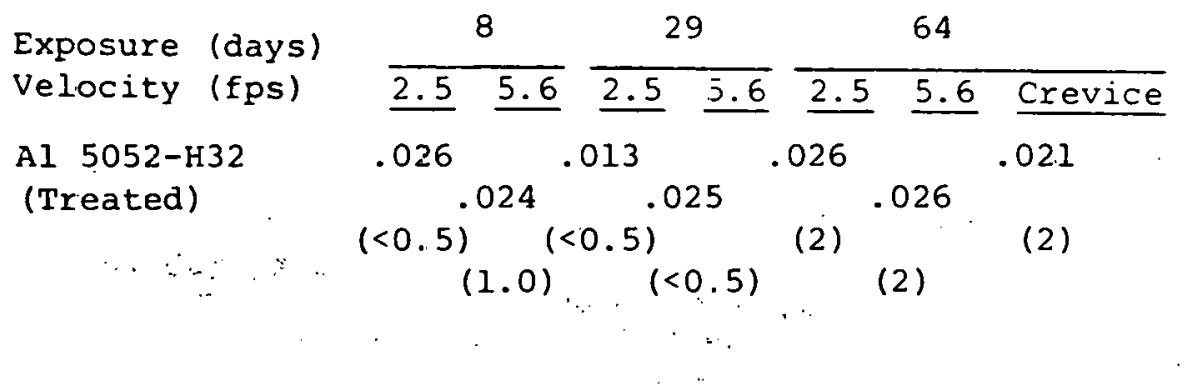

At 2.5 fps, a very few incipient pits at 8 and 29 days, increasing to 3 small pits and 2 pits at 64 days.

At $5.6 \mathrm{fps}$, a very few incipient pits and 1 small pit present at 8 days, and 2 pits present at 64 days.

slight srevice attack was noted at one point of the crevice specimen. A very few incipient pits, 2 small-pits, and 1 pit were observed elsewhere on the specimen.

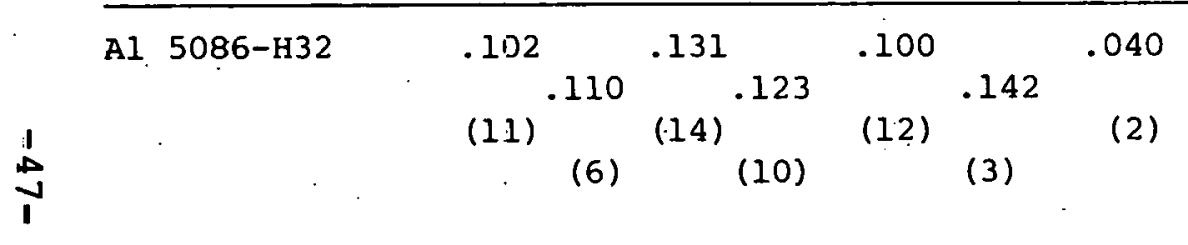

At 2.5 fps, a very few incipient pits and 4 large pits (up to $0.25 \mathrm{~cm}$ long and $11 \mathrm{mils}$ deep) were observed at 8 days. At 29 days, a few incipient pits, 2 small pits, and 1 pit $0.3 \mathrm{~cm}$ long and 14 mils deep were observed, and at 64 days, 2 small pits, 4 pits, and 2 large pits (up to $0.3 \mathrm{~cm}$ in length and $12 \mathrm{mils}$ penetration) were observed.

At 5.6 fps, a few incipient pits, and 4 large pits (up to $0.15 \mathrm{~cm}$ in diameter and 6 mils deep) were observed at 8 days, 2 large pits (up to a diameter of $.35 \mathrm{~cm}$ and $10 \mathrm{mils}$ deep) were observed at 29 days, and 3 small pits, 1 pit, and 3 large pits (to $0.10 \mathrm{~cm}$ diameter and $3 \mathrm{mils}$ deep) were observed at 64 days.

Crevice attack was noted at 9 points under the artificial crevice of the crevice specimen. In addition, a few incipient pits and 3 small pits were also observed. 
Tab1e IX-4 (continued)

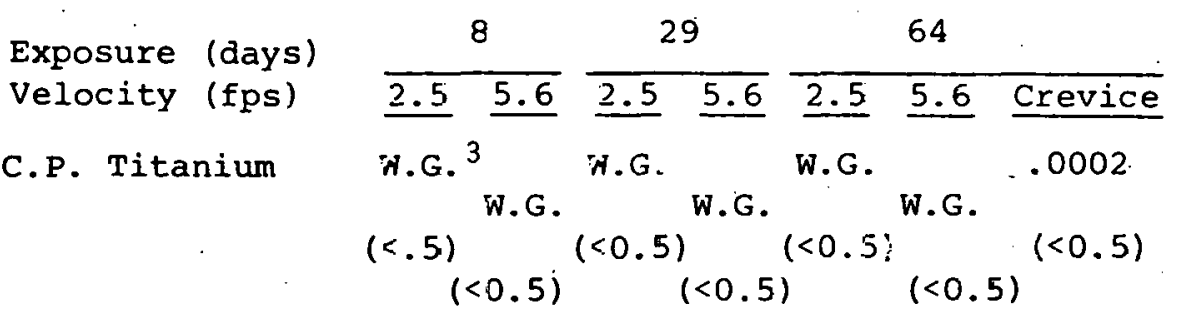

\section{Pitting Observations}

At $2.5 \mathrm{fps}$, a very few indipient pits at 8 days, and a few incizient pits at 29 and 64 days were observed.

At 5.6 fps, a few incipient pits at 8 and 29 days and several at 64 cays were observed.

A few incipiert pits, no crevice attack, were observed on the crevice specimen.

1 Total piveraqe perezration corrected for losses occurring during post exposure cleaning:

2 Because of the srall surface area of the ccupons and the srort period of exposure, pit:ing

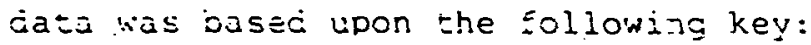

Incigient pitting: Pits less that 0.5 nils deep, discernable as pits uner 25 inagrification.

Sin:li. pits:

Pies:

Very Few:

Few:

Several:

Numercus:

3 Weight Gain
Pits 1.0-0.5 mils ceep, discernable as pit uncer jax nagnilication, and visible to raked Eye.

pits 1-2 mils deep (unless otherwise indicated), readily visible as pits to

naked eye.

Less than $5 / \mathrm{sq}$. in.

$5-10$,'sq. in.

$10-55 / \mathrm{sc}$. in.

More than 15/sq. - $n$. 
TABLE IX-5

CORROSION DATA FOR TEST

$5^{\circ} \mathrm{C}$ SEAWATER +8.5 PPM AMMONIA

Total Average Penetration (mils) ${ }^{l}$ and (Max. Pit Depth, mils)

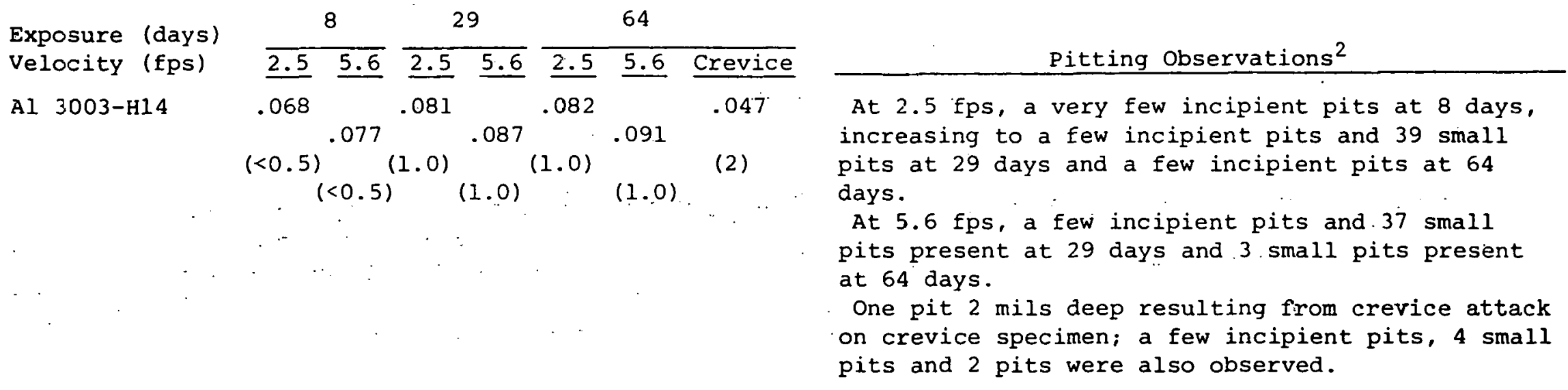

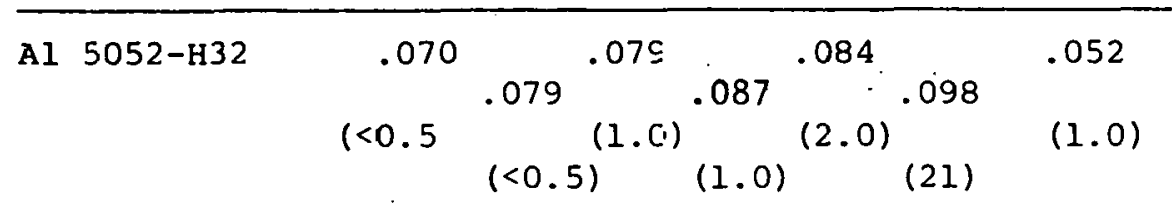

At 2.5 fps, a very few incipient pits at 8 days, increasing at 29 days to 7 small pits, increasing at 64 days to a few incipient pits, 2 small pits, and 1 pit.

At 5.6 fps, a very few incipient pits at 8 days, increasing to a few incipient pits and 4 small pits at 29 days, increasing to several incipient pits, 2 small pits, and two large pits (up to $0.25 \mathrm{~cm}$ length and 21 mils deep).

A very few incipient pits were noted on the crevice specimen with one surface etch and 1 small pit at the crevice.

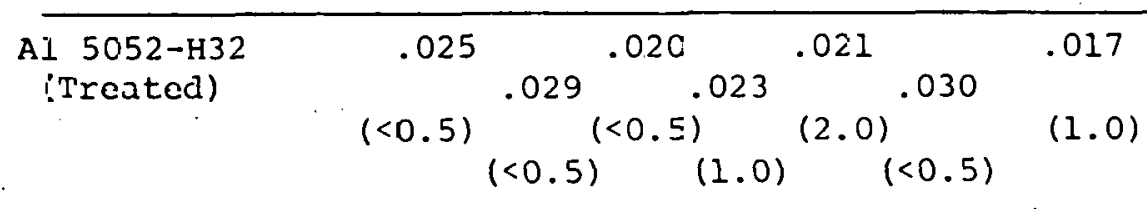

At 2.5 fps, a very few incipient pits were observed at 8 and 29 days, and one pit was observed at 64 days.

At $5.6 \mathrm{fps}$, a very few incipient pits were observed at 8 and 29 days, with 1 small pit at 29 days and a few incipient pits at 64 days.

A very tew Incipient pits and 1 small pit were noted on the crevice specimen. 
Table IX-5 (continued)

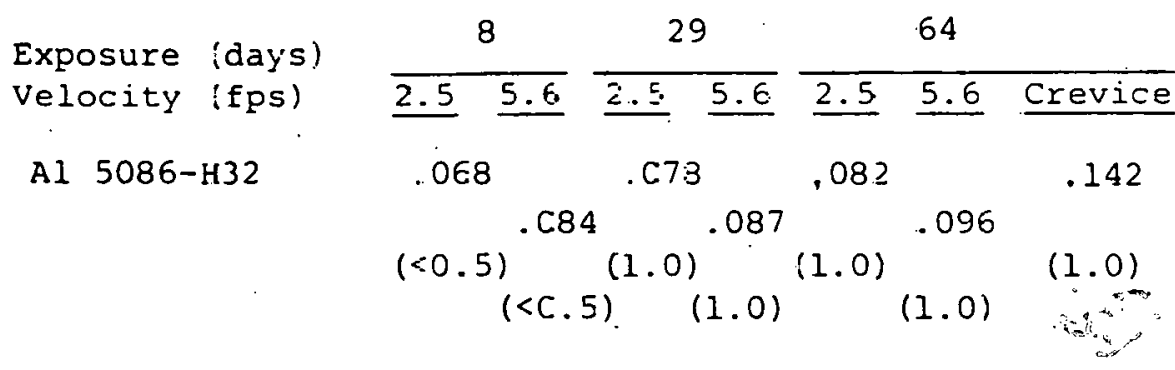

At 2.5 fps, a few incipient pits were observed at 8 and 29 days, with 17 small pits present at 29 days and several ircipient pits and 1 small pit at 64 days. At 5.6 fps, several incipient pits at 8 days, and

a few incipient pits and 11 small pits at 29 days and 1 small pit at 54 days.

A few incipient pits and 2 small pits were noted on the specimen surface.

$\begin{array}{cccc}\text { C.P. Titanium W.G. }{ }^{3} \text { W.G. } & \text { W.G. } & .0002 \\ & (<0.5) \text { W.G. }(<0.5)(<0.5) & (<0.5) \\ (<0.5)(<0.5)(<0.5) & \end{array}$

A few incipient pits were observed at all indicated exposures.

1 Total Average Penetratior. corrected for lcsses occurring during post exposure cleaning.

2 Because of the small surface area of the coupons and the short periot of exposure, pitting data was based ufon the following key:

Incipient pitting: Pits less that 0.5 mils deep, discernable as pies under $25 x$ magnification.

Sinall pits:

Pits:

Very Few:

Few :

Several:

Numerous:

3 Weight Gain
Pits 1.0-0.5 mils deep, discernable as pit under 10x magnification and visible to naked eye.

Pits 1-2 mils deep (unless otherwise indicated), readily visible as pits to r:aked eye.

Less than 5/sq. in.

$5-10 / \mathrm{sq}$. in.

$10-15 / s q$. in.

More than 15/sq. in. 
FOULING FORMATION

Seawater + Nominal 8.0 ppm Ammonia

and Ambient Temperature Seawater Controls

\begin{tabular}{|c|c|c|c|c|c|c|c|}
\hline \multirow{2}{*}{\multicolumn{2}{|c|}{$\begin{array}{l}\text { Substrate: } \\
\text { Velocity (Eps) }\end{array}$}} & \multicolumn{2}{|c|}{ Titanium } & \multicolumn{2}{|c|}{ Aluminum } & \multirow[b]{2}{*}{$\begin{array}{l}\text { Crevice } \\
\text { Unit } \\
(0.26 \\
\text { fps) } \\
\end{array}$} & \multirow[b]{2}{*}{ Comments } \\
\hline & & $\begin{array}{l}2.5 \\
S c\end{array}$ & $\begin{array}{l}5.6 \\
\text { ale }\end{array}$ & 2.5 & 5.6 & & \\
\hline $30^{\circ}$ & $\begin{array}{r}8 \\
29 \\
64\end{array}$ & $\begin{array}{l}1 \\
1.5 \\
1.5\end{array}$ & $\begin{array}{l}1.5 \\
1 \\
2\end{array}$ & $\begin{array}{l}1.5 \\
2 \\
2\end{array}$ & $\begin{array}{l}1 \\
1 \\
2\end{array}$ & 1.5 & $\begin{array}{l}\text { A dark brown deposit, thin and adherent, } \\
\text { with a tendency to flake when dry. On } \\
\text { aluminum, corrosion products form a } \\
\text { thicker deposit formation than the sur- } \\
\text { rounding scale. Crystalline deposit } \\
\text { components are aluminum and amorphous } \\
\text { components are probably sulfates, iron } \\
\text { oxide (hydroxide), and possibly } \mathrm{CaCO}_{3} .\end{array}$ \\
\hline $5^{\circ}$ & $\begin{array}{r}8 \\
29 \\
64\end{array}$ & $\begin{array}{l}<.5 \\
1.5 \\
1.5\end{array}$ & $\begin{array}{l}<.5 \\
1.5 \\
1.5\end{array}$ & 0.5 & $\begin{array}{l}0.5 \\
1 \\
1\end{array}$ & 1 & $\begin{array}{l}\text { A dark brown adherent deposit covers the } \\
\text { specimen in a uniform layer. Composition } \\
\text { is as for } 30^{\circ} \mathrm{C} \text {. }\end{array}$ \\
\hline Ambient & $\begin{array}{c}8 \\
29 \\
64\end{array}$ & $\begin{array}{l}<.5 \\
<.5 \\
1.5\end{array}$ & $\begin{array}{l}<.5 \\
<.5\end{array}$ & $\begin{array}{l}.5 \\
0.5 \\
1 .\end{array}$ & $\begin{array}{r}<.5 \\
0.5\end{array}$ & & $\begin{array}{l}\text { Initially a surface stain which develops } \\
\text { into a brown tan fouling deposit. Mud } \\
\text { with traces of organic matter is the } \\
\text { final product. Composition is as for } \\
30^{\circ} \mathrm{C} \text {. }\end{array}$ \\
\hline
\end{tabular}

\footnotetext{
${ }^{1}$ Pretreated aluminum alioy 5052 had a fouling behavior more similar to titanium than
} the remaining aluminum alloys. 
TPBLE IX -7

SUMMARY GF EXFOSURE CONDITIONS

- Nominal $8 \mathrm{ppm} \mathrm{NH}_{3}$

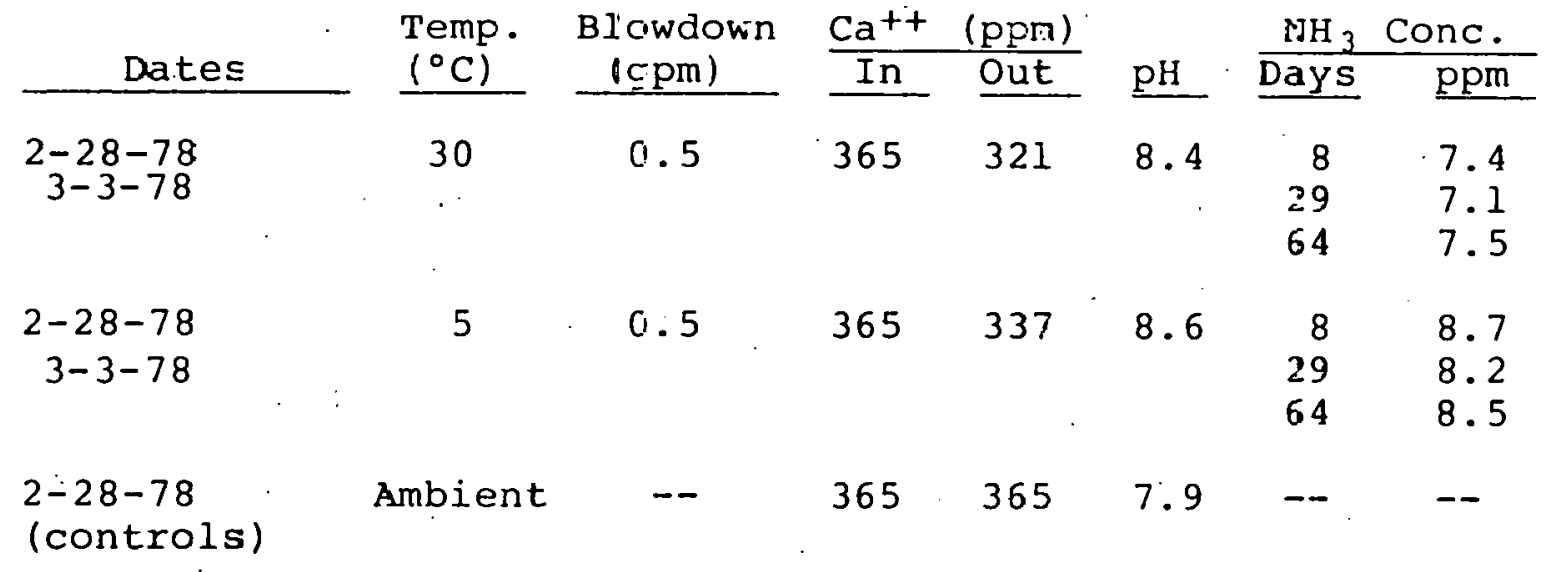




\section{TABLE IX -8}

FINAL INTERVAL CORROSION RATES (mPY) 1,2 FOR. TEST EXPOSURES OF 30.0 PPH AMMONIA IN SEAWATER

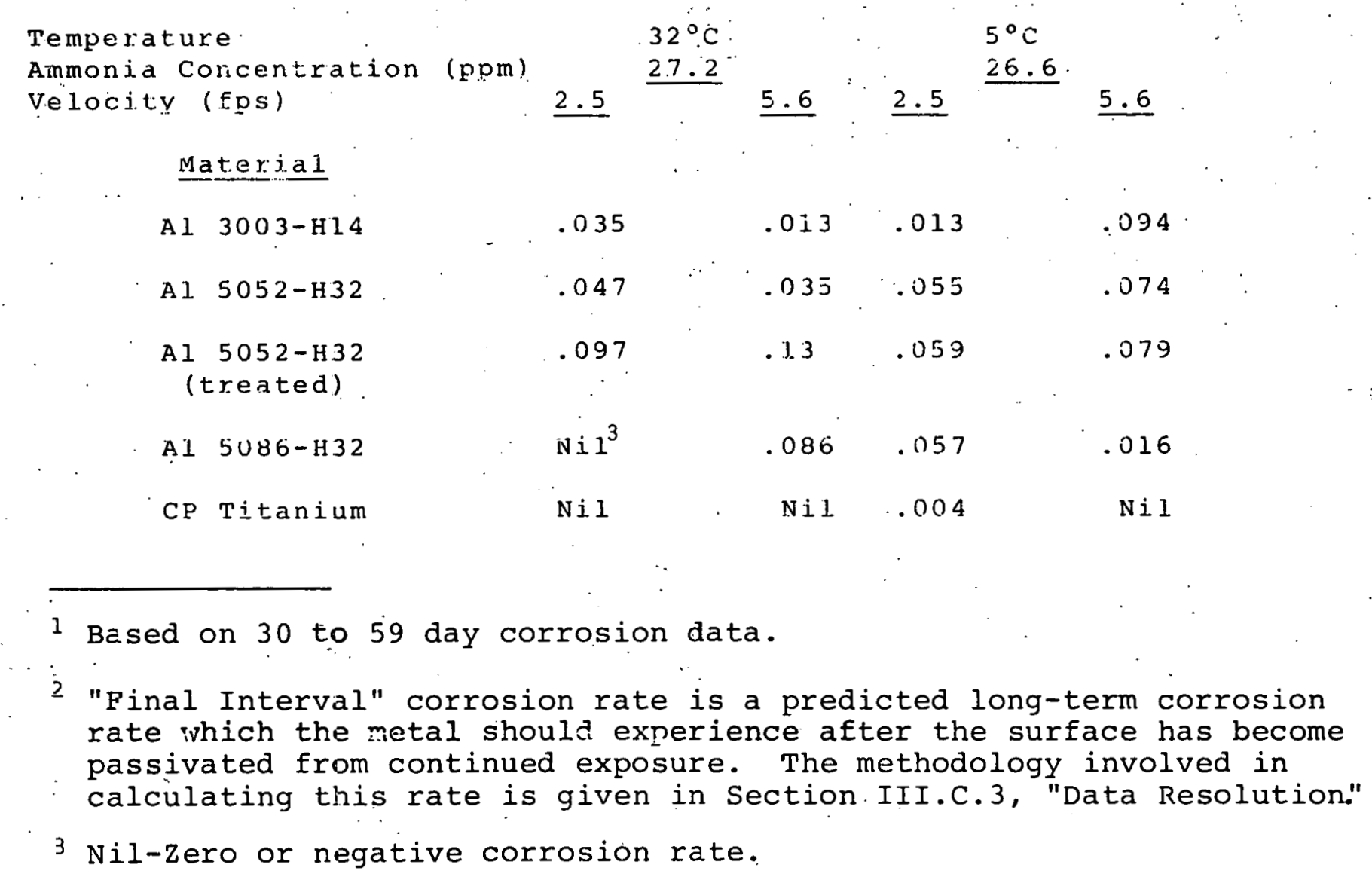

$\mathrm{Ni1} \quad .004$

$\mathrm{NiI}$

1 Based on 30 to 59 day corrosion data.

2 "Pinal Interval" corrosion rate is a predicted long-term corrosion rate which the metal should experience after the surface has become passivated from continued exposure. The methodology involved in calculating this rate is given in section. III.C.3, "Data Resolution."

3 Nil-zero or negative corrosion rate. 
TABLE IX -9

TOTAL AVERAGE PENETRATION (mils) FOR TEST EXPOSURES OF 30 PPM AMMONIA IN SEAWATEZ

\begin{tabular}{|c|c|c|c|c|c|c|c|}
\hline $\begin{array}{l}\text { Temperature } \\
\text { Ammonia Concen }\end{array}$ & ation (ppm) & & $\begin{array}{l}32^{\circ} \mathrm{C} \\
33.4\end{array}$ & & & & \\
\hline Velocity l Eeet & ex $\sec . j$ & Crevice & 2.5 & 5.6 & Crevize & 2.5 & 5.6 \\
\hline Material & $\begin{array}{c}\text { Ex:Fosure } \\
\text { idays) } \\
\end{array}$ & & & & & & \\
\hline Al 3003-HLA & $\begin{array}{l}14 \\
30 \\
59\end{array}$ & $\begin{array}{c}- \\
.016\end{array}$ & $\begin{array}{l}.026 \\
.028 \\
.031\end{array}$ & $\begin{array}{l}.033 \\
.036 \\
.037\end{array}$ & $\begin{array}{c}- \\
.0 \\
.057\end{array}$ & $\begin{array}{l}.029 \\
.033 \\
.034\end{array}$ & $\begin{array}{l}.031 \\
.036 \\
.044\end{array}$ \\
\hline A1. $5052-\mathrm{H}=2$. & $\begin{array}{r}14 \\
30 \\
59\end{array}$ &.$\overline{-}$ & $\begin{array}{l}.021 \\
.021 \\
.024\end{array}$ & $\begin{array}{l}.026 \\
.028 \\
.031\end{array}$ &.$\overline{-}$ & $\begin{array}{l}.031 \\
.030 \\
.034\end{array}$ & $\begin{array}{l}.036 \\
.033 \\
.039\end{array}$ \\
\hline $\begin{array}{c}\text { Al } 5052-\mathrm{H} 32 \\
\text { (Treated) }\end{array}$ & $\begin{array}{l}14 \\
30 \\
59\end{array}$ & $\frac{-}{-}$ & $\begin{array}{l}.020 \\
.028 \\
.029\end{array}$ & $\begin{array}{l}.020 \\
.021 \\
.031\end{array}$ & $\begin{array}{c}- \\
-003\end{array}$ & $\begin{array}{l}.003 \\
.010 \\
.015\end{array}$ & $\begin{array}{l}.012 \\
.010 \\
.016\end{array}$ \\
\hline Al $5086-\mathrm{H} 32$ & $\begin{array}{l}14 \\
30 \\
59\end{array}$ & $\begin{array}{c}- \\
.015\end{array}$ & $\begin{array}{l}.026 \\
.025 \\
.024\end{array}$ & $\begin{array}{l}.024 \\
.029 \\
.035\end{array}$ & $\begin{array}{c}- \\
-188\end{array}$ & $\begin{array}{l}.020 \\
.021 \\
.026\end{array}$ & $\begin{array}{l}.018 \\
.023 \\
.024\end{array}$ \\
\hline C.P. Titarium & $\begin{array}{l}14 \\
30 \\
59\end{array}$ & $\overline{-}$ & $\begin{array}{l}.002 \\
.0006 \\
\text { W.G. }\end{array}$ & $\begin{array}{l}.002 \\
\text { W.G. } \\
.0006\end{array}$ & $\overline{-}$ & $\begin{array}{l}.0004 \\
.0008 \\
.0011\end{array}$ & $\begin{array}{l}.002 \\
.0008 \\
.0006\end{array}$ \\
\hline
\end{tabular}

1 Weight Gain 
TABLE IX -10

COFROSION DATA FOR. TEST

$30^{\circ} \mathrm{C}$ Seawater $+27.2 \mathrm{ppm}$ Ammonia

Total Average Penetration (mils) ${ }^{l}$ and (Max. Pit Depth, mils)

\begin{tabular}{|c|c|c|c|c|c|c|c|}
\hline \multirow{2}{*}{$\begin{array}{l}\text { Exposure (days) } \\
\text { Velocity (fps) }\end{array}$} & \multicolumn{2}{|c|}{14} & \multicolumn{2}{|c|}{30} & \multicolumn{3}{|c|}{59} \\
\hline & 2.5 & 5.6 & 2.5 & 5.6 & 2.5 & 5.6 & Crevice \\
\hline $13003-\mathrm{H} 14$ & $\begin{array}{l}.026 \\
(<0.5)\end{array}$ & $\begin{array}{l}.033 \\
(2.0)\end{array}$ & $\begin{array}{c}.028 \\
(2.0)\end{array}$ & $\begin{array}{l}.036 \\
(2.0)\end{array}$ & $\begin{array}{l}.013 \\
(2.0)\end{array}$ & $\begin{array}{c}: \\
.037 \\
(1.0)\end{array}$ & $\begin{array}{l}.016 \\
(<0.5)\end{array}$ \\
\hline
\end{tabular}

Pitting Observations ${ }^{2}, 4$

At 2.5 fps, a very few incipient pits were observed at 14 days with several incipient pits, one small pit, and one pit at 30 days and one pit observed at 59 days.

At 5.6 fps, a very few incipient pits and one pit were observed at 14 days, several incipient pits, one small pit, and one pit at 30 days, and one small pit at 59 days.

A few incipient pits were observed on the crevice specimen.

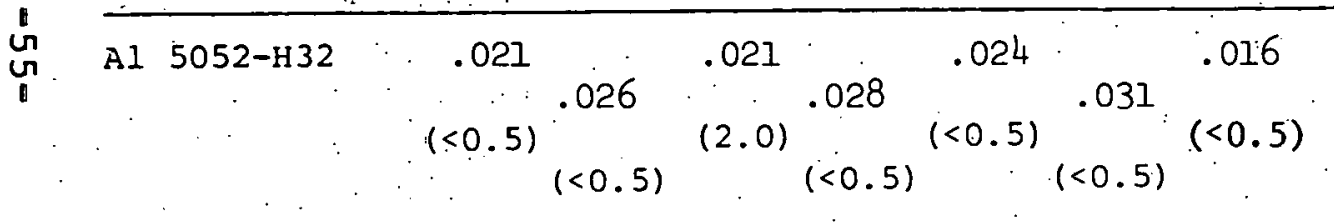

At. 2.5 fps, a very few incipient pits were observed at 14 däys, with an additional pit at 30 days and $\dot{a}$ few incipient pits observed at 59 days.

At $5.6 \mathrm{fps}$, a few incipient pits were observed:

A few incipient pits were observed on the crevice specimen.

\begin{tabular}{|c|c|c|c|c|c|c|c|}
\hline $\begin{array}{l}\text { A1 } 5052-\mathrm{H} 32 \\
\text { (Treated) }\end{array}$ & $\begin{array}{l}.0 z 0 \\
(<0.5)\end{array}$ & $\begin{array}{l}.020 \\
(<0.5)\end{array}$ & $\begin{array}{c}.028 \\
(<0.5)\end{array}$ & $\begin{array}{l}.021 \\
(<0.5)\end{array}$ & $\begin{array}{c}.029 \\
(1.0)\end{array}$ & 031 & .023 \\
\hline
\end{tabular}

At 2.5 fps,' a few incipient pits were observed at 14 days and an additional two smali pits were observed at 59 days.

At $5.6 \mathrm{fps}$, a few incipient pits were observed.

The crevice specimen had a very few incipient pits and 2 small pits. 
$\underline{\text { Table } I X-10}$ (continued)

\begin{tabular}{|c|c|c|c|c|c|c|c|c|}
\hline Exposure (days) & 1 & & & 30 & & 59 & & \\
\hline Velocity (fps) & 2.5 & 5.6 & 2.5 & 5.6 & 2.5 & 5.6 & Crevice & Eitting Observations 2,4 \\
\hline $15086-\mathrm{H} 32$ & $\begin{array}{l}.026 \\
(<0.5)\end{array}$ & $\begin{array}{l}.024 \\
(<0.5)\end{array}$ & $\begin{array}{l}.025 \\
1<0.5 !\end{array}$ & $\begin{array}{l}.029 \\
(2.0)\end{array}$ & $\begin{array}{l}.024 \\
(1.0)\end{array}$ & $\begin{array}{l}.035 \\
(\div 0.5)\end{array}$ & $\begin{array}{l}.015 \\
(<0.5)\end{array}$ & $\begin{array}{l}\text { At } 2.5 \text { fps, a very few incipient pits were } \\
\text { observed at } 14 \text { and } 30 \text { days, with the addi- } \\
\text { tion of one smal: pit at } 59 \text { days. } \\
\text { At } 5.6 \text { fps, a very few incipient pits were } \\
\text { observed wi=h one pit present at } 30 \text { days. } \\
\text { A very few incipient pits were observed on } \\
\text { the crevice specimen. }\end{array}$ \\
\hline
\end{tabular}

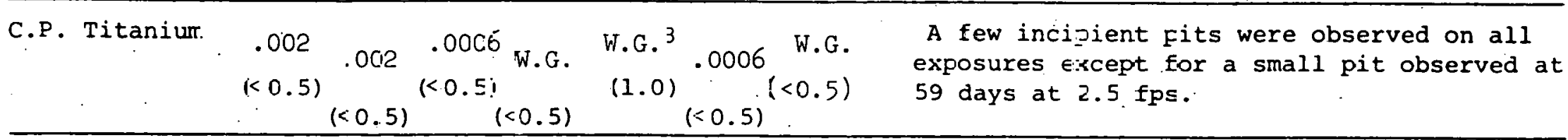

1 Total Average Penetration corrected for losses occurrirg during post exposure cleaning.

2 Because of the small surface area of the coupons and the short perioc of exposure, pitting data was based upon the following key:

Incipient pitting: Pits less than 0.5 mils deep, discernable as pi=s under $25 x$ magnification.

Small pits: Pits 1.0-0.5 mils deep, discernable as pits under 10x magnification and visible to nakec eye.

Pits: Pits 1-2 mils deep (ünless otherwise indicated), readily visible: as píts to naked eye.

Very Few: Less than 5/sq. in.

Few: $\quad 5-10 / 5 c$. in.

Several: 10-15/sq. in.

Numerous: More tian 15/sq. in.

3 Weight Gain.

4 Max. pit depth $0.5-2.0 \mathrm{mil}$ on any specimen. 
TABLE IX- 11

CORROSION DATA EOR TEST

$5^{\circ} \mathrm{C}$ Sèwater $+26.6 \mathrm{ppm}$ Ammonia

Total Average Penetration (mils) ${ }^{l}$ and (Max. Pit Depth, mils)

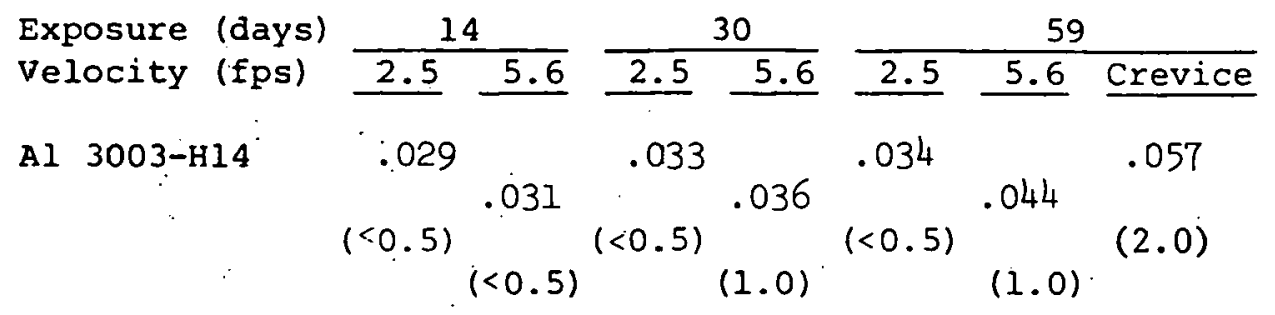

Pitting Observations ${ }^{2}, 3$

At 2.5 fps, a few incipient pits were observed.

At 5.6 fps, a few incipient pits were observed at 14 days, one small pit at 30 days, and four small pits at 59 days.

on the crevice specimen, several incipient pits and one pit were observed in addition to eight small pits and nine pits resulting from crevice attack.

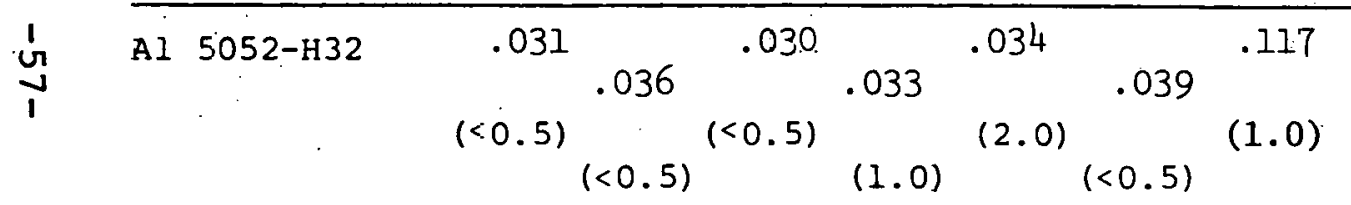

At 2.5 fps, a few incipient pits were observed at 14 and 30 days, with an additional small pit and pit present at 59 days. At 5.6 fps, a few incipient pits were observed with two small pits present at 30 days.

On the crevice specimen, several incipient pits were observed in addition to three small pits resulting from crevice attack.

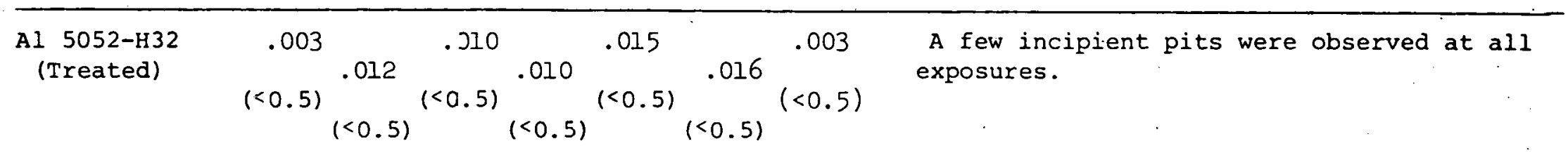


Table IX-1I (continued)

\begin{tabular}{|c|c|c|c|c|c|c|c|}
\hline \multirow{2}{*}{$\begin{array}{ll}\text { Exposure (days) } \\
\text { Velocity (fps) }\end{array}$} & \multicolumn{2}{|c|}{14} & \multicolumn{2}{|c|}{30} & \multicolumn{3}{|c|}{59} \\
\hline & 2.5 & 5.6 & 2.5 & 5.6 & 2.5 & 5.6 & Crevice \\
\hline $15086-\mathrm{H} 32$ & .020 & .018 & .021 & .023 &.$\approx 26$ & .024 & .188 \\
\hline & $(<0,5)$ & $(<0.5)$ & $(<0.5)$ & $(<0.5)$ & $(2.0)$ & $(<0.5)$ & $(2.0)$ \\
\hline
\end{tabular}

-

\section{$P=$ tting Observations $^{2}$}

At 2.5 fps, a few incipient pits at 14 days increasing to one small pit at 59 days. At 5.E fps, a few incipient pits were observed.

On the crevice specimen, several incipient pits and eight small pits were observed with and additional nine small pits and three pits resultirig from crevice attack.

\begin{tabular}{|c|c|c|c|c|c|c|c|}
\hline P. Titan & $\begin{array}{l}.0004 \\
(<0.5)\end{array}$ & $\begin{array}{l}.002 \\
(<0.5)\end{array}$ & .0008 & $.0008^{.0011}$ & $\begin{array}{l}.0006 \\
(<0.5)\end{array}$ & $\begin{array}{l}.0005 \\
(<0.5)\end{array}$ & $\begin{array}{l}\text { At } 2.5 \text { fps and } 5.6 \text { fps, several incipient } \\
\text { pits were noted. } \\
\text { On the crevice specimen, a very few } \\
\text { incipient pits were present. }\end{array}$ \\
\hline
\end{tabular}

Totál Aver was based upon the following key:

Incipient pitting: Pits less than 0.5 mils deep, discernable as pits under $25 x$ magnification. Small pits: Fits $1.0-0.5 \mathrm{mils}$ deep, discernable as pits under $10 \mathrm{x}$ nagnification and visible to raked eye.

Pits: Pits $1-2$ mils deep (unless otherwise indicated), readily visible as pits to naked eye.

Very Few: Less than 5/sq. in.

Few: $5-10 / \mathrm{sq}$. in.

Several: $10-15 / \mathrm{sq}$. in.

Numerous: More than 15/sq. in.

Max. pit depth $0.5-2.0$ mil on any specimen. 
TABLE IX -1.2

FOULING FORMATION

Seawater + Nominal 30 ppm Ammonia

and Ambient Temperature Seawater Controls

\begin{tabular}{|c|c|c|c|c|c|c|c|}
\hline \multicolumn{2}{|c|}{$\begin{array}{l}\text { Substrate: } \\
\text { Velocity (fps) }\end{array}$} & \multicolumn{2}{|c|}{ Titanium } & \multicolumn{2}{|c|}{ Aluminum } & \multirow[b]{2}{*}{$\begin{array}{l}\text { Crevice } \\
\text { Unit } \\
(0.26 \\
\text { fps }) \\
\end{array}$} & \multirow[b]{2}{*}{ Comments } \\
\hline $\begin{array}{l}\text { Velocity } \\
\text { Temp., } \\
{ }^{\circ} \mathrm{C} \\
\end{array}$ & $\begin{array}{l}\text { (fps) } \\
\text { Period, } \\
\text { days } \\
\end{array}$ & 2.5 & 5.6 & 2.5 & 5.6 & & \\
\hline 30 & $\begin{array}{l}14 \\
30 \\
59\end{array}$ & $\begin{array}{l}0.5 \\
4 \\
27\end{array}$ & $\begin{array}{l}0.5 \\
1.5 \\
14\end{array}$ & $\begin{array}{r}2.0 \\
6 \\
29\end{array}$ & $\begin{array}{l}1.5 \\
3 \\
14\end{array}$ & 17 & $\begin{array}{l}\text { A hard, adherent, light brown scale } \\
\text { which may be removed from the specimen } \\
\text { by flexing the metal coupon. } \\
\text { Primary constituents of the scale are } \\
\text { two crystalline forms of } \mathrm{CaCO}_{3} \text {, calcite } \\
\text { and aragonite. }\end{array}$ \\
\hline 5 & $\begin{array}{l}14 \\
30 \\
59\end{array}$ & $\begin{array}{r}<0.5 \\
0.5 \\
1.5\end{array}$ & $\begin{array}{r}<0.5 \\
0.5 \\
0.5\end{array}$ & $\begin{array}{r}<0.5 \\
1.0 \\
1.5\end{array}$ & $\begin{array}{r}<0.5 \\
<0.5 \\
1.0\end{array}$ & 4 & $\begin{array}{l}\text { A thin, adherent, light brown deposit } \\
\text { with no tendency to chip or flake. } \\
\text { Calcite is the major crystalline com- } \\
\text { ponent present, with trace amounts of } \\
\mathrm{Ca}(\mathrm{OH})_{2} \text {, CaCl } 2 \text {, and quartz also present. }\end{array}$ \\
\hline Ambient & $\begin{array}{l}14 \\
30 \\
59\end{array}$ & & $\begin{array}{l}1.0 \\
1.0 \\
1.5\end{array}$ & & $\begin{array}{l}1.0 \\
1.0 \\
3.0\end{array}$ & & $\begin{array}{l}\text { A muddy; dark brown deposit on specimen } \\
\text { surface. A clay of the mica group } \\
\text { (ferriphlogopite) is the primary } \\
\text { crystalline component present. }\end{array}$ \\
\hline
\end{tabular}

1 Pretreated aluminum alloy 5052 had a fouling behavior more similar to titanium than the remaining aluminum alloys. 
TABLE IX -13

\section{SUMMARY OF EXPOSURE CONDITIONS}

Nominal $30 \cdot \mathrm{ppm} \mathrm{NH}_{3}$

\begin{tabular}{|c|c|c|c|c|c|c|c|}
\hline Dates & $\begin{array}{l}\text { Temp. } \\
\left({ }^{\circ} \mathrm{C}\right) \\
\end{array}$ & $\begin{array}{l}\text { Blowdown } \\
\text { (gpm) }\end{array}$ & $\frac{\mathrm{Ca}++}{\mathrm{In}}$ & $\frac{(\mathrm{ppm})}{\text { Out }}$ & $\mathrm{pH}$ & $\frac{\mathrm{NH}_{3}}{\text { Days }}$ & onc. \\
\hline $\begin{array}{l}5-15-78 \\
7-15-78\end{array}$ & 30 & 0.5 & 460 & 400 & 8.91 & $\begin{array}{l}14 \\
30 \\
59\end{array}$ & $\begin{array}{l}33.4 \\
2.4 .5 \\
27.2\end{array}$ \\
\hline $\begin{array}{l}5-15-7 \varepsilon \\
7-15-78\end{array}$ & 5 & 0.5 & 460 & 449 & 8.99 & $\begin{array}{l}14 \\
30 \\
59\end{array}$ & $\begin{array}{l}24.3 \\
25.7 \\
26.6\end{array}$ \\
\hline $\begin{array}{c}5-15-7 \varepsilon \\
7-15-78 \\
\text { (contrc.ls) }\end{array}$ & Ambient & -- & 460 & 460 & 8.0 & -- & -- \\
\hline
\end{tabular}


TABLE IX- 14

FINAL INTERVAL CORROSION RATES (mPY) 1,2 FOR TEST EXPOSURES OF 80 pPm AMMONIA

Temperature
Ammonia Concentration (ppm)

velocity (fps)

Material
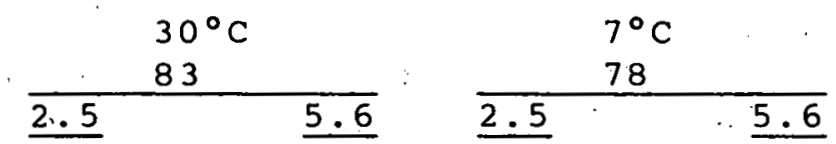

$$
1.68
$$

1.43

.60

1.22

Nil
2.46

$\mathrm{Nil}^{3}$

.025

1.80

Nil

.040

$\mathrm{Ni} 1$

Nil

Ni1
A $15086-\mathrm{H} 32$
CP Titanium

1.53
Nil

$\mathrm{N}$ i 1

\footnotetext{
1 Based on 30 to $50\left(30^{\circ} \mathrm{C}\right)$ and 32 to $51\left(5^{\circ} \mathrm{C}\right)$ corrosion data.

2 "Final Interval" corrosion rate is a predicted long-term corrosion rate which the metal should experience after the surface has become passivated from continued exposure. The methodology involved in calculating this rate is given in Section III.C.3, "Data Resolution."
}

3 Nil-zero or negative corrosion rate. 
TOTAL AVERAGE PENETRATION (mils) FOR

TEST EXPOSURES OF 30 PPM AMMONIA IN SEAWATER

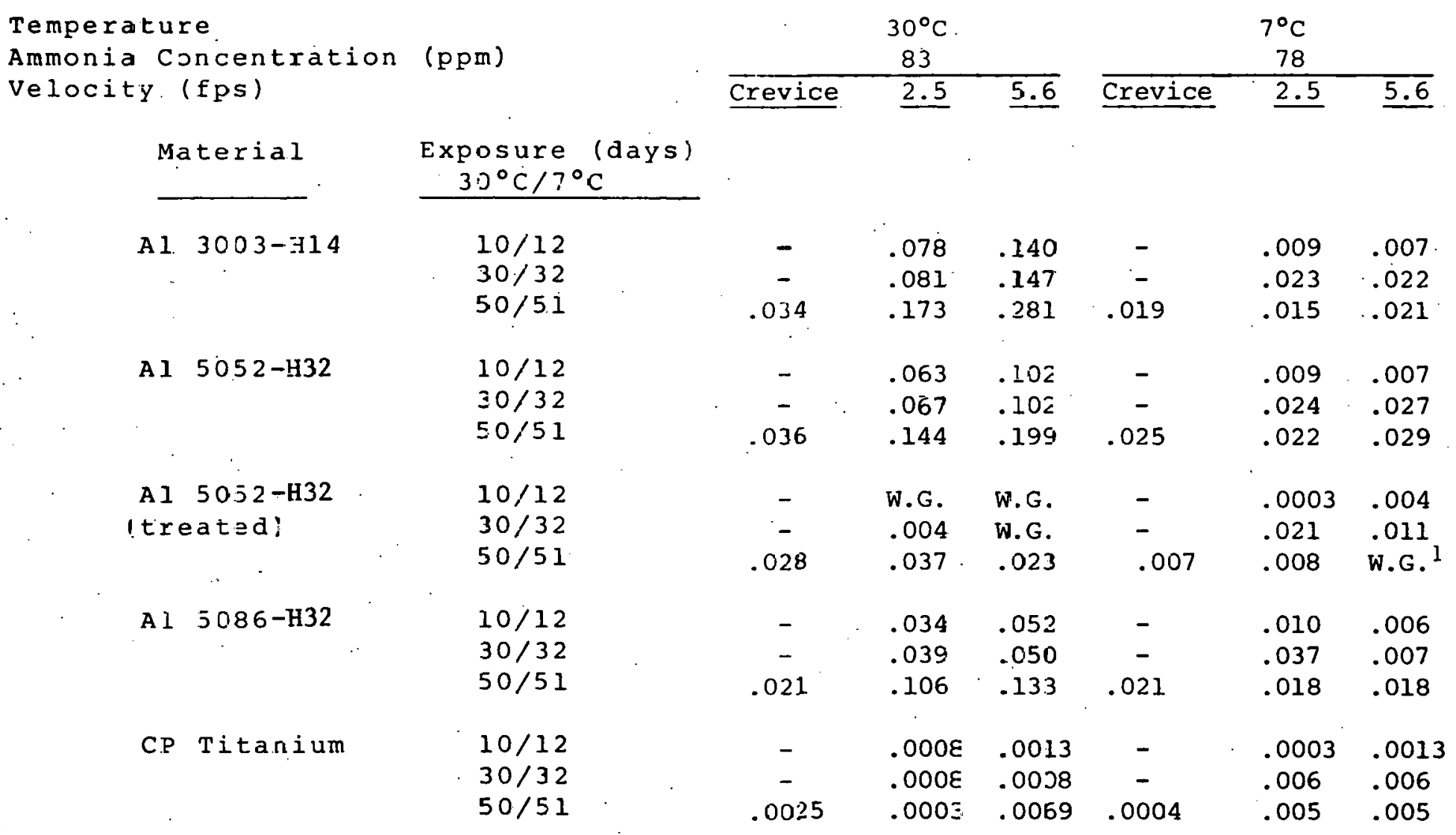

1 Weigint Gain 
TABLE IX-16

CORROSION DATA FOR TEST

$30^{\circ} \mathrm{C}$ Seawater + Nominal $80 \mathrm{ppm}$ Ammonia (Avg. $83 \mathrm{ppm}$ )

Total Average Penetration (mils) ${ }^{1}$ and (Max. Pit Depth, mils)

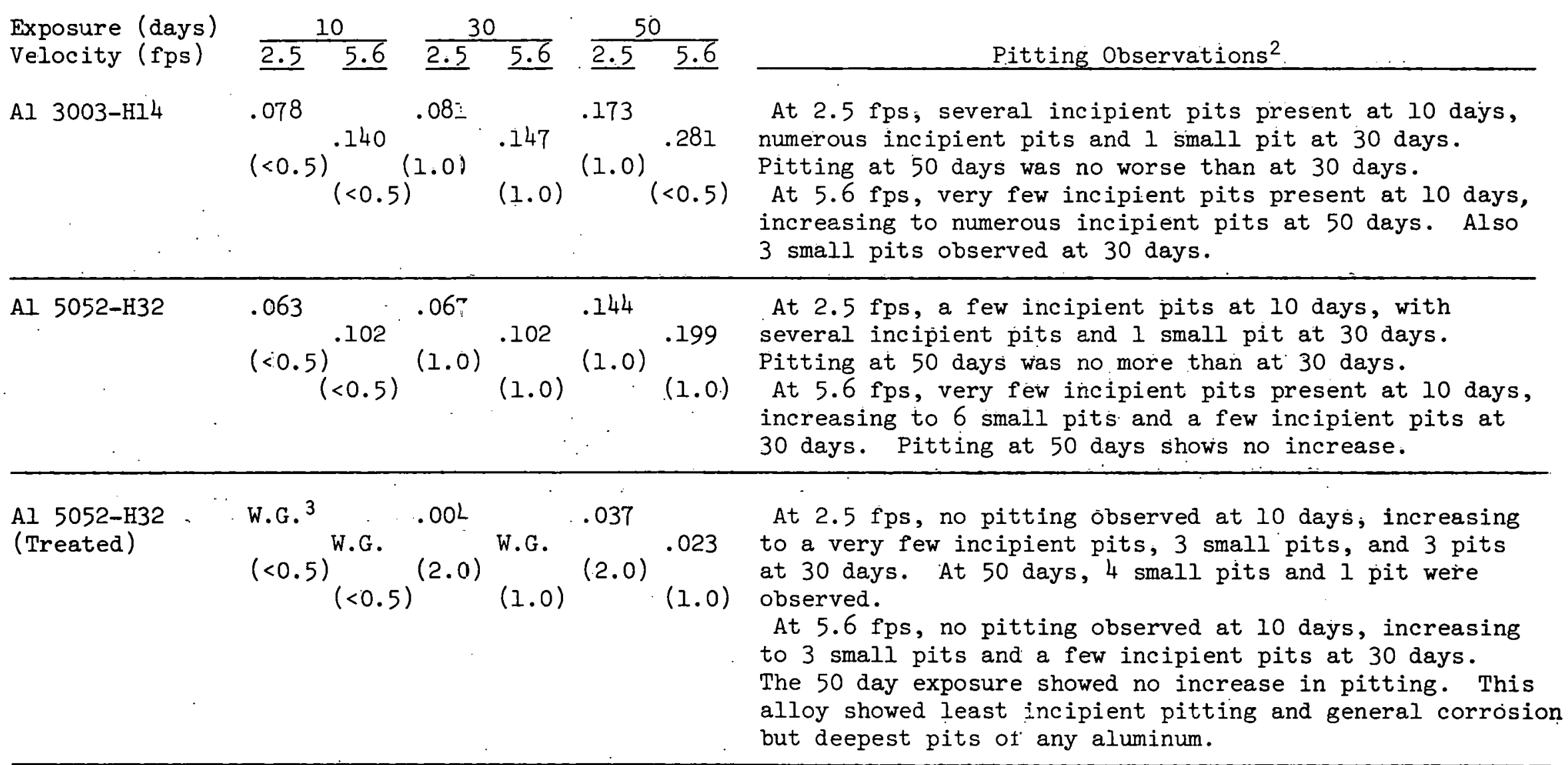

Al $5086-\mathrm{H} 32$

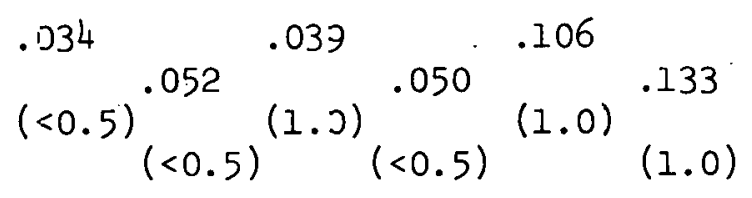

At the $2.5 \mathrm{fps}$, very few incipient pit sites at 10 days, increasing to a few incipient pits and 1 small pit at 30 days, increasing to 3 small pits at 50 days.

A.t 5.6 fps, a very few incipient pits were observed until 50 days, when a few incipient pit sites and 1 small pit were observed. Best pit resistance of any Al alloy tested. 
TABLE IX-16 continued

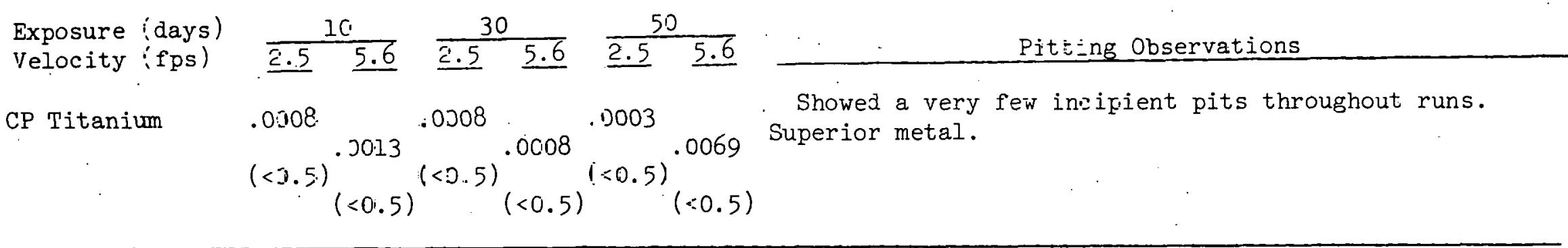

1 Total Averaqe Peretration correctec for losses occurring curing post expcsure cleaning.

2 Because of the small surface area of tize coupons and the short period o exposure, pitting data was based upon the Eollowing key:

Incigient pitting: Pits less that $0.5 \mathrm{mils}$ deep, discernable as pits under $25 x$ magnification.

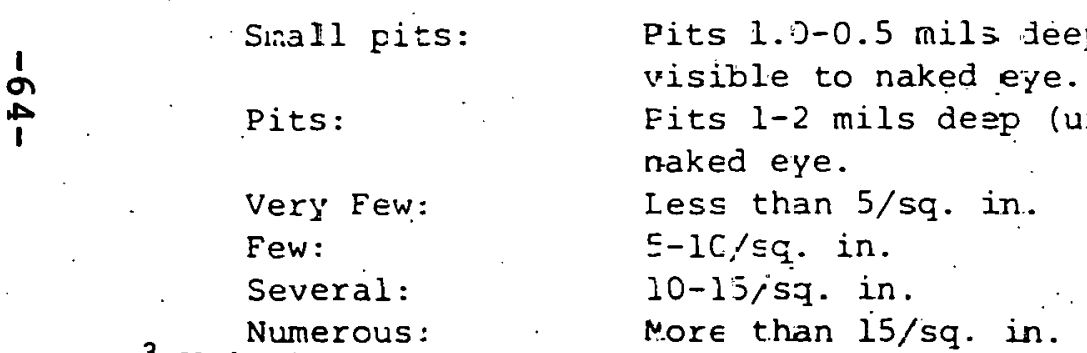


TABLE IY- 17

CORROSION DATA FOR CREVICE CORROSION TEST

$30^{\circ} \mathrm{C}$ Seawater $+83 \mathrm{ppm}$ Ammonia for 50 Days

Alloy
Al $3003 \mathrm{H}-14$$\quad \frac{\begin{array}{c}\text { Total Average Penetration } \\ \text { mils }\end{array}}{.034} \quad \frac{\begin{array}{c}\text { Crevice Attack and } \\ \text { Pitting observations }\end{array}}{\begin{array}{l}\text { A surface mar was observed on the crevice } \\ \text { area, and a few incipient pits were noted } \\ \text { on the outlying surface. }\end{array}}$

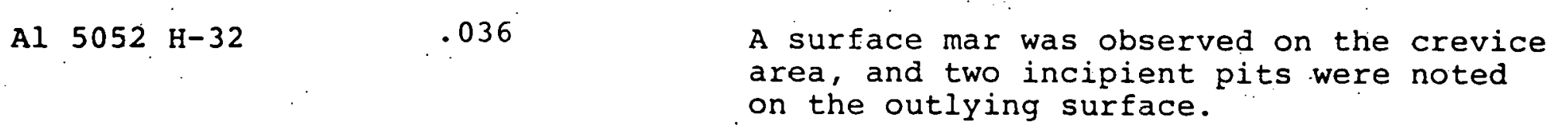

No indication of any crevice effect. One small pit and a few incipient pits were. noted on the outlying surface.

\begin{tabular}{lll} 
Al $5086 \mathrm{H}-32$ & .021 & $\begin{array}{l}\text { A slight surface mar was observed on the } \\
\text { crevice area and two incipient pits were } \\
\text { noted on the outlying surface. }\end{array}$ \\
\hline CP Titanium & .0025 & $\begin{array}{l}\text { A slight surface mar. was observed on the } \\
\text { crevice area and two incipient pits noted } \\
\text { on the outlying surface. }\end{array}$
\end{tabular}

1 Legend for pitting observations are as for previous table. A surface nar is considered to be a surface discoloration on the metal surface with no measurable depth attack. 
TABLE IX-18

COPROSION DATA FOR TEST

$7^{\circ} \mathrm{C}$ Seawater + Norinal $80 \mathrm{ppm}$ Anmonia (Avg. $78 \mathrm{ppm}$ )

Total hverage Penetration (mils) ${ }^{1}$ and ( $l$ lax. Pit Depth, mils)

\begin{tabular}{|c|c|c|c|c|c|c|}
\hline \multirow{2}{*}{$\begin{array}{l}\text { Exposure (days) } \\
\text { Velocity (fps) }\end{array}$} & $\frac{\text { Total }}{12}$ & \multicolumn{2}{|c|}{$\frac{\text { Averaie }}{32}$} & \multicolumn{2}{|c|}{ etration } & \multirow[b]{2}{*}{ Pitting Observations ${ }^{2}$} \\
\hline & $2.5 \quad 2.6$ & 2.5 & 2.6 & 2.5 & 2.6 & \\
\hline Al $3003-\mathrm{H} 14$ & ${ }_{(1.0)^{.007}}^{.009}$ & $\begin{array}{l}.023 \\
(1.0)\end{array}$ & $\begin{array}{l}.022 \\
(<0.5)\end{array}$ & $\begin{array}{l}.015 \\
(2.0)\end{array}$ & $\begin{array}{l}.021 \\
(1.0)\end{array}$ & $\begin{array}{l}\text { At } 2.5 \text { fps, }=\text { Eew incipient pits were observed at } \\
12,32 \text {, and } 51 \text { lays, with one small pit present at } \\
12 \text { and } 32 \text { days, increasing to one pit at } 51 \text { days. } \\
\text { At } 5.6 \text { fps; a few incipient pits were present at } \\
12 \text { days, increasing to numerous incipitent pits at } \\
32 \text { days. Two small pits were also observed at } 12 \\
\text { and } 51 \text { days. }\end{array}$ \\
\hline
\end{tabular}

\begin{tabular}{|c|c|c|c|c|}
\hline Al $5052-\mathrm{H} 32$ & $\underbrace{.009}_{(<0.5)^{.007}}$ & $\begin{array}{l}.024 \\
(2.0)^{.02 ?} \\
(1.0)\end{array}$ & $\begin{array}{l}.022 \\
(2.0)_{(2.0)}^{.029}\end{array}$ & $\begin{array}{l}\text { At } 2.5 \text { fps, a few incipient pits were observed at } \\
12,32 \text {, and } 5 \text { days, with three small pits and one } \\
\text { pit present at } 3.2 \text { days and four small pits and one } \\
\text { pit observed at } 51 \text { days. } \\
\text { At } 5.6 \text { fps, a few incipitent pits were observed } \\
\text { at } 12,32 \text {, and } 51 \text { cays, with one small pit present } \\
\text { at } 32 \text { days and two small pits and one pit observed } \\
\text { at } 51 \text { days. }\end{array}$ \\
\hline
\end{tabular}

\begin{tabular}{|c|c|c|c|c|c|}
\hline $\begin{array}{l}\text { A1 } 5052-\mathrm{H} 32 \\
\text { (Treated) }\end{array}$ & & $\begin{array}{l}.021 \\
(1.0)\end{array}$ & $\begin{array}{l}.011 \\
(1.0 !\end{array}$ & $\begin{array}{l}.008 \\
(2.0)\end{array}$ & $\begin{array}{l}\text { W.G. } \\
(2.0)\end{array}$ \\
\hline
\end{tabular}

At 2.5 fps, ¿ Eew incipient pits and one small were observed at 12 days, increasing to a few incipient pits, three small pits, and four pits after 51 days.

At 5.6 fps, a few incipient pits were observed at 12,32 , and $5 i$ lays, including one small pit at 32 days, increasing to four small pits and one pït at 51 days.

\section{(continued)}


Table IX-I8. Continued

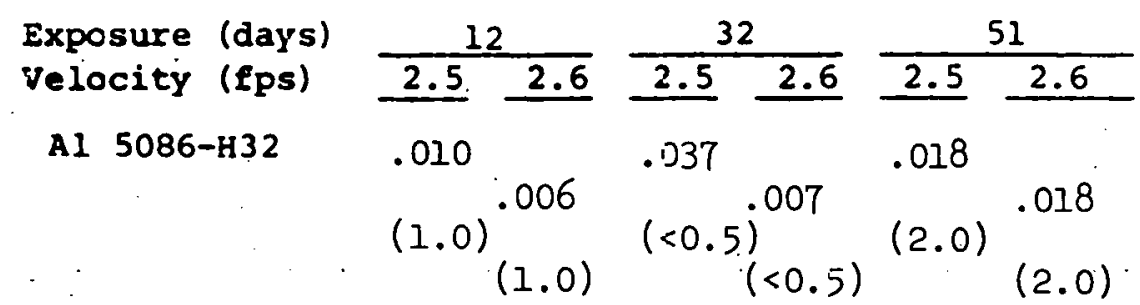

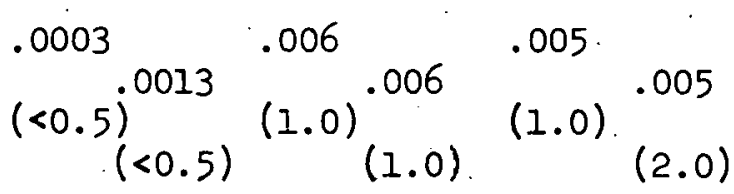

\section{Pitting Observations}

At 2.5 fps, a few incipients pits were observed at 12,32 , and 51 days, with five small pits observed at 12 days and three small pits and one pit present at 51 days.

At $5.6 \mathrm{fps}$, several incipient pits and three small pits were observed at 12 days, increasing to three small pits and three pits at $\mathbf{5 l}$ days.

At $2.5 \mathrm{fps}$, a few incipient pits were present at 12 days, increasing to several incipient pits and two small pits at 32 days, increasing to several incipient pits and four small pits at 51 days. At $5.6 \mathrm{fps}$, several incipient pits were present at 12,32 , and 51 days, with seven small pits present at 32 days and three small pits and one pit present at 51 days.

Total Average Penetration corrected for losses occurring during post exposure cleaning.

Because of the small surface area of the coupons and the short period of exposure, pitting data was based upon the following key:

Incipient pitting: Pits less than $0.5 \mathrm{mils}$ deep, discernable as pits under $25 x$ magnification.

Small pits: Pits $1.0-0.5$ mils deep, discernable as pits under $10 \mathrm{x}$ magnification and visible to naked eye.

Pits: Pits 1 - 2 mils deep (unless otherwise indicated), readily visible as pits to naked eye.

Very Few: Less than $5 / \mathrm{sq}$. in.

Few: $\quad 5-10 / \mathrm{sq}$. in.

Several: $10-15 /$ sq. in.

Numerous: More than 15/sq. in. 
TABLE IX-19

Corrosion Data for Crevice Corrosion Tes:

$7{ }^{\circ} \mathrm{C}$ Seawater $+73 \mathrm{ppm}$ Ammonia for 51 Days

Alloy Total Average Penetration Crevice Attack and Pi=ting Observation 1 (mils)

\begin{tabular}{|c|c|c|}
\hline AI $3003 \cdot \mathrm{H}-14$ & .019 & $\begin{array}{l}\text { Slight surface attack was noted on the } \\
\text { crevice area, and a fər incipient pits; } \\
\text { two small pits, and one pit were present } \\
\text { on the outlying surfaze. }\end{array}$ \\
\hline
\end{tabular}

\begin{tabular}{|c|c|c|}
\hline$\dot{\mathrm{A}} \mathrm{L} 5052 \mathrm{H}-32$ & .025 & $\begin{array}{l}\text { Slight surface attack and three small pits } \\
\text { were present at the crevice, and several } \\
\text { incipient fits and two small pits were } \\
\text { observed on the outlying surface. }\end{array}$ \\
\hline $\begin{array}{l}\text { Al } 5052 \mathrm{H}-32 \\
\text { (Treated) }\end{array}$ & .007 & $\begin{array}{l}\text { One slight mar was noted at the crevice, } \\
\text { and a very few incipient pits and one small } \\
\text { pit were observed on the outlying surface. }\end{array}$ \\
\hline
\end{tabular}

$\begin{array}{ll}\text { A1. } 5086 \mathrm{H}-32 \quad .021 & \begin{array}{l}\text { Surface attack and }=0 u r \text { small pits were } \\ \text { observed at the crevice, and a few incip- } \\ \text { ient pits and one small pit were observed }\end{array} \\ \text { on the outlying surface. }\end{array}$

\begin{tabular}{ll}
\hline CP Titanium $\quad$ GC04 & $\begin{array}{l}\text { A few incipient pits and eight small pits } \\
\text { were found distributec over the specimen } \\
\text { surface. }\end{array}$ \\
\hline
\end{tabular}

1 Legend for pitting opservations are as for previous table. A surface mar is considered to be a surface discoloration on the metal surface with no measurable depth attack. 
TABLE IX-20

\section{SCALE FORMATION \\ Seawater + Nominal 80 ppm Ammonia}

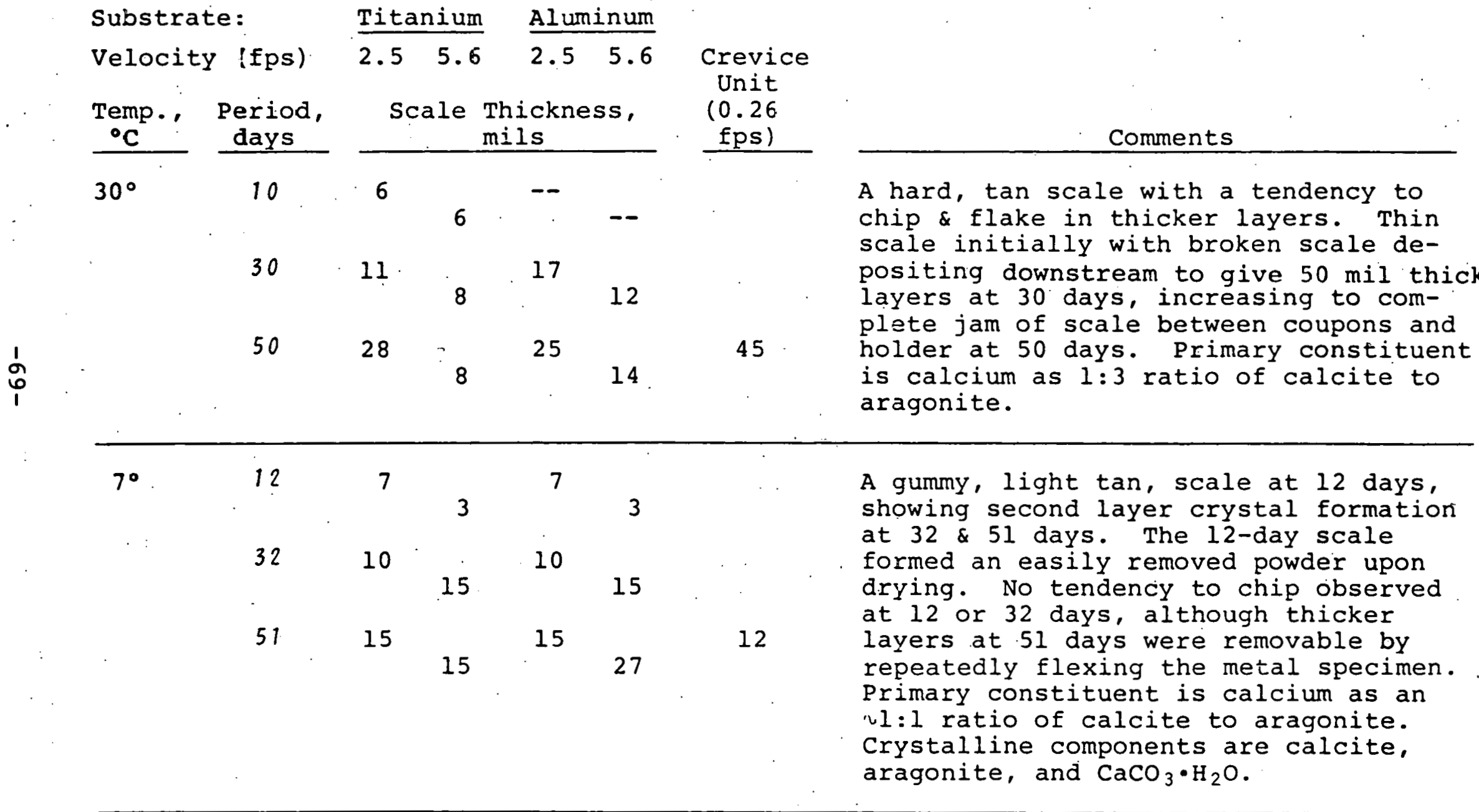




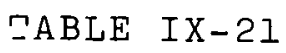

2.0

$433 \quad 361$

9.410

87

30

84

50

83

Test Unit II

$10-2 \bar{b}-77-$ 7

.5

$408 \quad 364$

9.8

12

88

$12-19-77$ 
TABLE IX-22

FINAL INTERVAL CORROSION RATES (mPY) 1,2,3 FOR TEŚT EXPOSURES OF 800. PPM AMMONIA IN SEAWATER

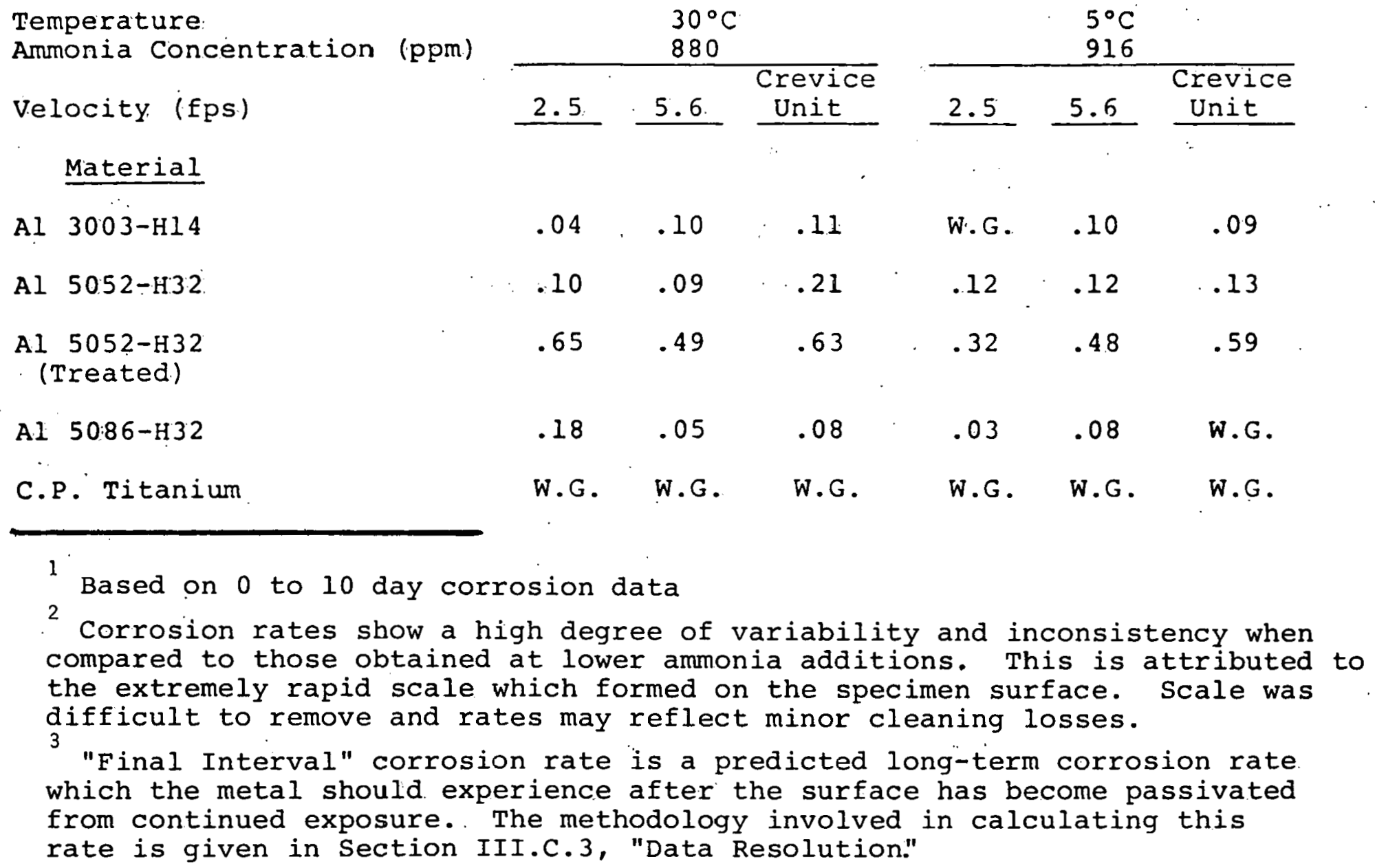


TABLE IX-23

TOTAL AVERAGE PENETRATION (mils) AFTER 10 DAYS FOR TEST EXPCISURES OF 800 PPM AMMONIA IN SEAWATER ${ }^{1}$

\begin{tabular}{|c|c|c|c|c|c|c|}
\hline $\begin{array}{l}\text { Temperature } \\
\text { Ammonia Concentrition (ppm) }\end{array}$ & \multicolumn{3}{|c|}{$\begin{array}{l}30^{\circ} \mathrm{C} \\
880^{-}\end{array}$} & \multicolumn{3}{|c|}{$\begin{array}{l}5^{\circ} \mathrm{C} \\
916\end{array}$} \\
\hline Velocity (fps) & 2.5 & 5.6 & $\begin{array}{l}\text { Crevice } \\
\text { Unit }\end{array}$ & 2.5 & 5.6 & $\begin{array}{l}\text { Crevice } \\
\text { Unit }\end{array}$ \\
\hline Material & . & & & & & \\
\hline Al 3003-Hl4 & .001 & .003 & .003 & W.G. & .003 & .002 \\
\hline AI $5052-\mathrm{H} 32$ & .003 & .002 & .006 & .003 & .003 & .003 \\
\hline $\begin{array}{c}\text { Al } .5052-\mathrm{H} 32 \\
\text { (Treated) }\end{array}$ & .018 & .013 & .017 & .008 & .012 & .015 \\
\hline Al 5086-H32 & .005 & .001 & .002 & .0008 & .002 & W.G. \\
\hline C.P. Titanium & W.G. & W.G. & W. G. & W.G. & W.G. & W.G. \\
\hline
\end{tabular}

1 Penetrations show a high degree of variability and inconsistency when compared to those obtained at iower ammonia additions. This is attributed to the extremely rapid scale which formed on the specimen surface. Scale was difficult to remove and rates may reflect minor cleaning losses. 
TABLE IX-2L

CORROSION DATA FOR TEST 5

$30^{\circ} \mathrm{C}$ Seawater +880 Ammonia (10 days)

Total Average Penetration (mils $)^{1}$ and (Max. Pit Depth, mils)

Total Average Pezetration

Velocity (fps) $2.5 \quad 5.6 \quad$ Crevice

Pitting and Crevice Attack ${ }^{2}, 4$

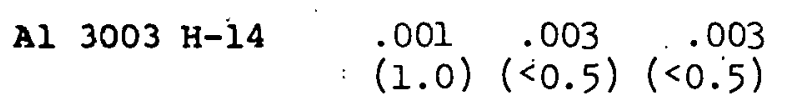

At 2.5 fps, a very few incipient pits \& one small pit.

At 5.6 fps, a very few incipient pits. A very few incipient pits on the crevice specimens. A surface mar was present on the crevice area.

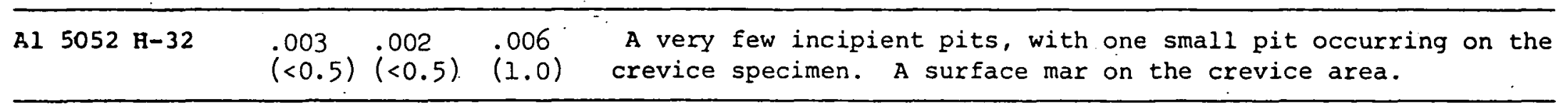

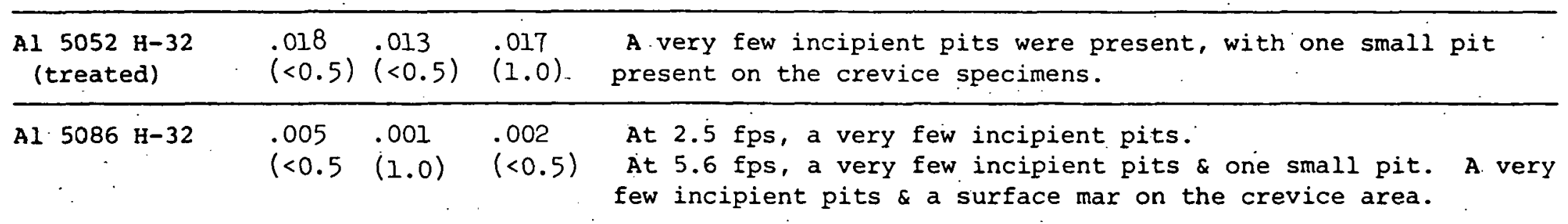

\begin{tabular}{lccc}
\hline C.P. Titanium & $\begin{array}{c}\text { W.G. } \\
(<0.5)\end{array}$ & $\begin{array}{c}\text { W.G. } \\
(<0.5)\end{array}$ & $\begin{array}{c}\text { W.G. } \\
(<0.5)\end{array}$
\end{tabular} . A very few incipient pits:

1 Total Average Penetration corrected for losses occurring during post exposure cleaning.

2 Because of the small surface area of the coupons and the short period of exposure, pitting data

was based upon the following l:ey:

Incipient pitting: Pits less than $0.5 \mathrm{mils}$ deep, discernable as pits under $25 x$ magnification.

Small pits: Pits 1.0-0.5 mils deep, discernable as pit under 10x magnification and visible to naked eye.

Pits: Pits 1-2 mils deep (unless otherwise indicated), readily visible as pits to naked eye.

Very Few: Less than 5/sq. in.

Eew: $5-10 / \mathrm{sq}$. in.

Several: $10-15 / \mathrm{sq}$. in.

Numerous: More than 15/sq. in.

3 Weight Gain

4 Max. pit depth observed was $<1.0 \mathrm{mil}$ for any specimen.

5 Discontinued at 10 days because of severe scaling. 
CORROSION DATA FOR TEST 5

$5^{\circ} \mathrm{C}$ seawater + $916 \mathrm{ppm}$ Ammonia (10 day.s)

Total Average Penetration (milsil

and (Max. Pit Dep=h, Mils)

Velocity (fps). $2.5 \quad 5.6$ Crevice

Pitting and Erevice Attack 2,4

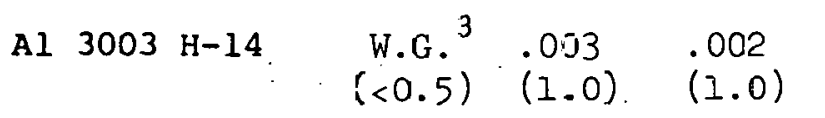

At $2: 5$ fps, a very few incipient pits.

At 5.6 fps, a very incipient pits $\&$ one small pit. The crevice specimens showed a very few incipient pits, 2 small pits, \& a small surface mar on the crevice area.

\begin{tabular}{|c|c|c|c|c|}
\hline Al $5052 \mathrm{H}-32$ & $\begin{array}{l}.003 \\
(<0: 5)\end{array}$ & $\begin{array}{l}.003 \\
(<0.5)\end{array}$ & $i_{(<0.5)}^{.003}$ & $\begin{array}{l}\text { A very few incipient pits. A small surface mar is present } \\
\text { on the crevice area. }\end{array}$ \\
\hline $\begin{array}{l}\text { Al } 5052 \mathrm{H}-32 \\
\text { (Treated) }\end{array}$ & $\stackrel{0008}{i<0.5)}$ & $\begin{array}{c}.012 \\
(<0.5)\end{array}$ & $\begin{array}{l}015 \\
(<0.5)\end{array}$ & A very few incipient pits. \\
\hline A1 $5086 \mathrm{H}-32$ & $\begin{array}{l}.0068 \\
i<0.5)\end{array}$ & $\begin{array}{l}.002 \\
(<0.5) \\
\end{array}$ & $\begin{array}{l}\text { W.G. } \\
(<0.5)\end{array}$ & A very few incipient pits. \\
\hline C.P. Titanium & $\begin{aligned} & \text { W.G. } 3 \\
&(<0.5)\end{aligned}$ & $\begin{array}{l}\text { W. } . E . \\
(<0.5)\end{array}$ & $\begin{array}{l}\text { W.G. } \\
(<0.5)\end{array}$ & $\begin{array}{l}\text { A few incipient pits at } 2.5 \text { fps and } 5.6 \text { fps, and a very fen } \\
\text { incipient pits on the crevice specimens. }\end{array}$ \\
\hline
\end{tabular}

Total Average Penetration corrected for losses occurring during post exposure cleaning.

2 Because of the small surface area of the coupons and the short period of exposure, pitting data was based upon the following key:

Incipient pitting: Pits less than 0.5 rils deep, discernable as $\equiv$ its under $25 x$ magnification. Small pits: Pits 1.0-0.5 mils deeg, discernable as pit under 10x magrification and visible to naked eye.

Pits: Pits 1-2 mils deep (unless otherwise indicated), readily risible as pits to naked eye.

Very Few: Less than 5.'sq. in.

Few: $5-10 / \mathrm{sq}$. in.

Several: $10-15 / \mathrm{sq}$. i..

Numerous: More than 15;sq. in.

3 Weight Gain

4 Max. pit depth observed was <1.0 mil for any specimen.

5 Discontinued at. 10 days because of severe scaling. 
TABLE IX-26

SCALE FORMATION

Seawater $+800 \mathrm{ppm}$ Ammonia

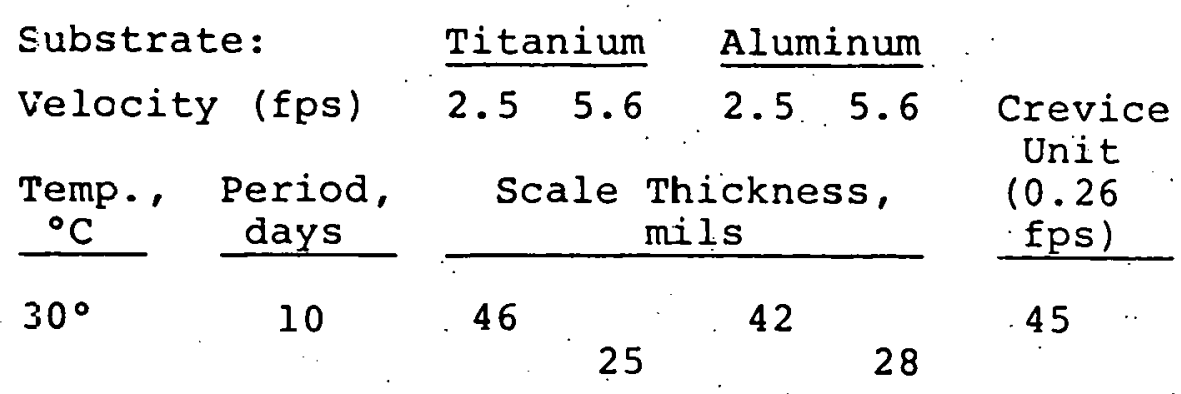

Comments

A hard, tan, brittle scale with a tendency to form small chips ( $22 \mathrm{~cm} \mathrm{sq.)}$ and showing no tendency to break free without specimen flexing. Primary constituents are aragonite $\left(\mathrm{CaCO}_{3}\right)$ and magnesium hydroxide $\left(\mathrm{Mg}(\mathrm{OH})_{2}\right)$ in an ح.1-3.7 ratio.

\begin{tabular}{|c|c|c|c|c|c|c|c|}
\hline $5^{\circ}$ & 9.5 & 17 & 25 & 14 & 40 & 11 & $\begin{array}{l}\text { A white, soft, gummy scale with a } \\
\text { tendency to form second layer crystals. } \\
\text { No tendency to chip. Primary constit- } \\
\text { uents are aragonite and magnesium } \\
\text { hydroxide in an } 22.6-5.2 \text { ratio. }\end{array}$ \\
\hline
\end{tabular}

Ambient

$<1$

$<1$

$<1$

$<1$

A very thin scale forming at most a discoloration on the metal surface. 
TABLE IX-27

SUMMARY OF EXPOSURE CONDITIONS $\left(-800\right.$ ppm $\left.\mathrm{NH}_{3}\right)$

\begin{tabular}{|c|c|c|c|c|c|c|c|}
\hline \multirow[b]{2}{*}{ Dates } & \multirow[b]{2}{*}{$\begin{array}{l}\text { Temp. } \\
\left({ }^{\circ} \mathrm{C}\right)\end{array}$} & \multirow[b]{2}{*}{$\begin{array}{l}\text { Blowdown } \\
\text { (gpn) }\end{array}$} & \multicolumn{2}{|c|}{$\mathrm{Ca}^{++}$(ppm) } & \multirow[b]{2}{*}{$\mathrm{pH}$} & \multicolumn{2}{|c|}{$\begin{array}{c}\text { Average } \\
\text { Antonia Conc }\end{array}$} \\
\hline & & & In & Out & & Days & ppm \\
\hline $\begin{array}{l}\text { Test Unit I } \\
1 / 30,77- \\
2 / 9,78\end{array}$ & $30^{\circ}$ & .5 & 329 & 224 & 10.5 & 10 & 880 \\
\hline $\begin{array}{c}\text { Test Onit II } \\
1 / 30 ; 78- \\
2 / 9 ; 78\end{array}$ & $5^{\circ}$ & .5 & 329 & 264 & 11.5 & 9.5 & 916 \\
\hline $\begin{array}{c}\text { Test Unit IJ } \\
1 / 30 / 78- \\
2 / 9 / 78\end{array}$ & Anb & -- & 329 & -- & -- & 10 & 0 \\
\hline
\end{tabular}


TABLE IX-28

CORROSION DATA FOR TEST

FINAL INTERVAL CORROSION. RATES 1,2 :

AMMONIA PLUS SEAWATER AT $5^{\circ} \mathrm{C}$

Seawater Concentration

Velocity (fps)

Al $3003-\mathrm{H} 14$

Al $5052-\mathrm{H} 32$

Al 5052-H32

(treated)

Àl $5086-\mathrm{H} 32$

CP Titanium
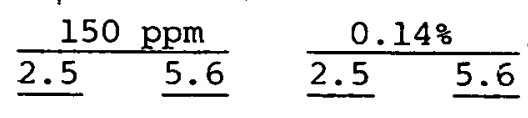

$\frac{1.12 \%}{2.5 \quad \underline{5.6}}$

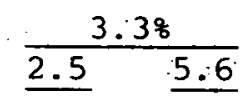

$\begin{array}{llll}.09 & .13 & \mathrm{Nil}^{3} \quad .43\end{array}$

$.21 \quad .19$

.08

.11

.009

.69

.35

.40

.53

$.98 \quad 1.09$

.08

.05

$\mathrm{Nil} \mathrm{Nil}$

.29

$.026 \quad .11 \quad .033$

$.23 \quad .29$

.12

.63

.51

.67

.87

1.19

$\mathrm{Ni1} .006$
$\mathrm{Nil}$

Nil $\quad .003$

1 Based upon corrosion data for final two specimen pulls.

2 "Final Interval" corrosion rate is a predicted long-term corrosion rate which the metal should experience after the surface has become passivated from continued exposure. The methodology involved in calculating this rate is given in Section III.C.3, "Data Resolution"

${ }^{3} \mathrm{Nil}$-Zero or negative corrosion rate. 
CORROSION DATA FOR TEST

$5{ }^{\circ} \mathrm{C}$ AIJHYDROUS AMMONIA

Total Average Penetration (r.ils) ${ }^{l}$ and (Max. Pit Depth. nils)

\begin{tabular}{|c|c|c|c|c|}
\hline Exposure (days) & 10 & & 38 & \\
\hline Velocity (fps) & 2.55 .6 & 2.5 & 5.5 & Erevice \\
\hline Al 3003-El 14 & .006 & .014 & & .014 \\
\hline & (5) & & $\begin{array}{l}.019 \\
(1.0)\end{array}$ & \\
\hline
\end{tabular}

Pitting Observations 2,3

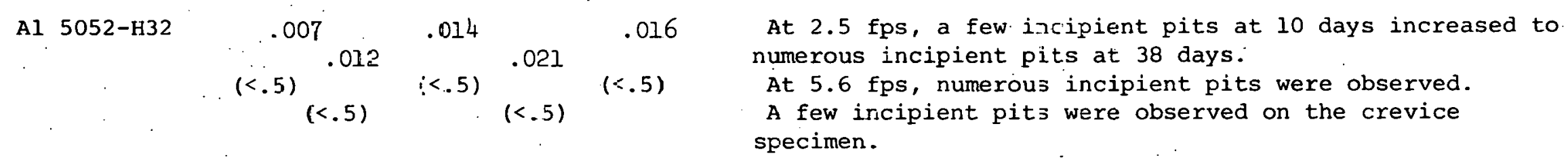

At 2.5 fps, a very Eew ircipient pits were observed, at 10 days, increasing to a few incipient pits at 38 days.

At 5.6 fps, a few incipient pits, were observed at 10 and 38 days with two small pits observed at 38 days.

$A$ very few incipient pits were observed on the crevice specimen.

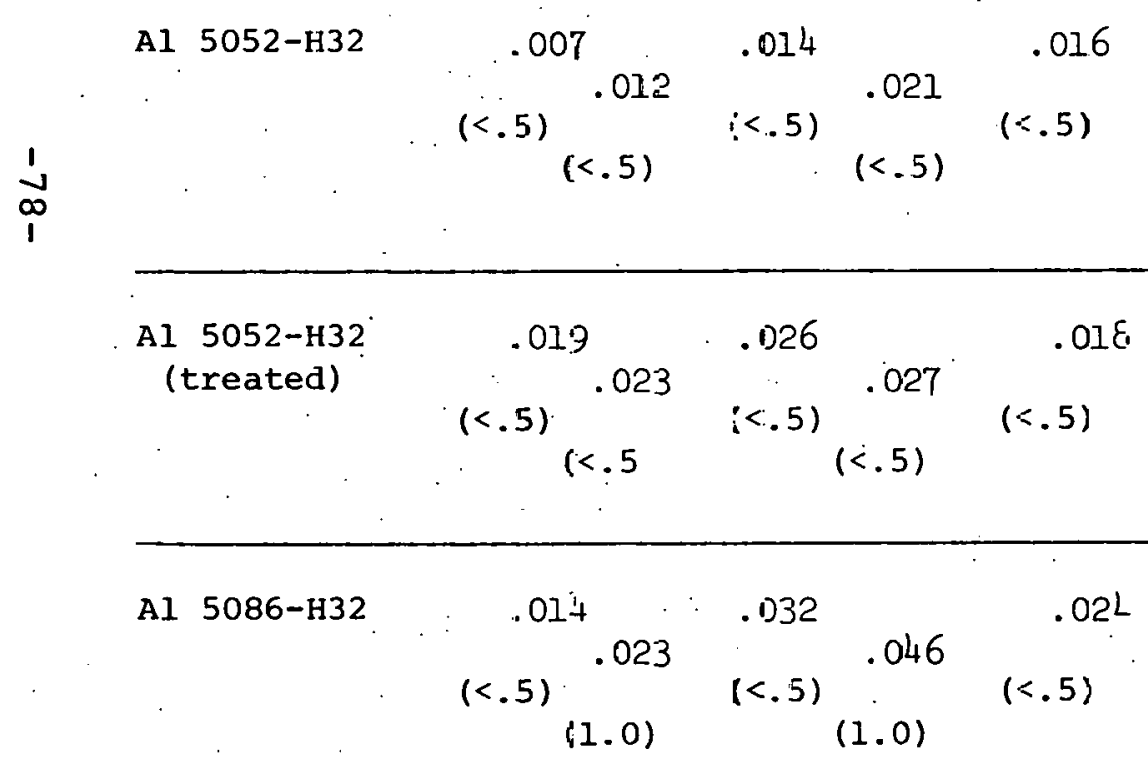

At 2.5 fps, a few incipient pits at 10 days increased to numerous incipient pits at 38 days.

At 5.6 fps, numerous incipient pits were observed, with five small pits observed at 10 days and eleven small pits observed at 38 days. A very few incipient pits were observed on the crevice specimens. 


\section{Table IX-29 continued}

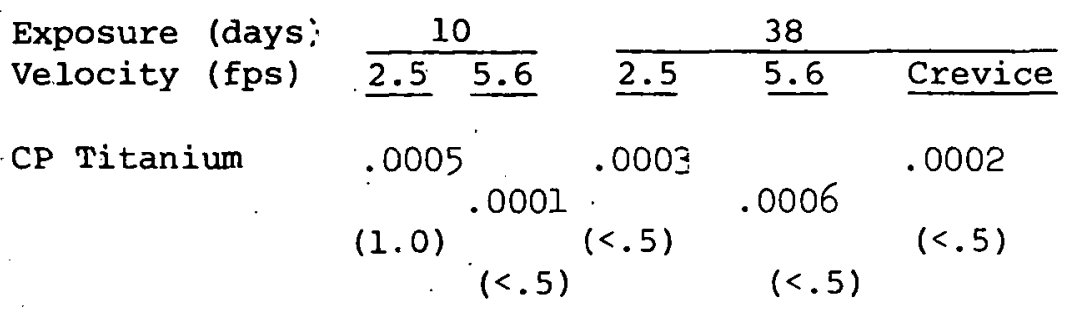

1 Total Average Penetration corrected for losses occurring during post exposure cleaninr.

2. Because of the small surface area of the coupons and the short period of exposure, pitting data was based upon the following key:

Incipient pitting: Pits less than 0.5 mils deep, discernable as pits urder $25 x$ magnification. Small pits: Pits 1.0-0.5 mils deep, discernable as pit under $10 x$ magnification and visible to naked eye.

Pits: Pits l-2 mils deep (unless otherwise indicated), readily visible as pits to naked eye.

Very Few: Less than 5/sq. in.

Few: $5-10 / \mathrm{sq}$. in.

Several: 10-15/sq. in.

Numerous: More than 15/sq. in.

3 Max. pit depth $0.5-1.0 \mathrm{mil}$ on any specimen. 
TAELE IX- 30

SUMMARY GF EXFOSURE CONDITICNS

FOR AMFYDROLS AMMONIA TEST

\begin{tabular}{|c|c|c|c|}
\hline Date & $\begin{array}{c}\text { Period, } \\
\text { days }\end{array}$ & $\begin{array}{l}\text { Temperature } \\
{ }^{\circ} \mathrm{C}\end{array}$ & $\begin{array}{l}\text { Water, } \\
\text { בכm }\end{array}$ \\
\hline $8-17-73$ & 0 through & $5^{\circ}$ & ALO \\
\hline $8-27-78$ & 10 & - & \\
\hline $8-29-73$ & 10 through & $5^{\circ}$ & 151 \\
\hline $9-26-78$ & 38 & & \\
\hline
\end{tabular}


TABLE IX- 31

TOTAL A.VERAGE PENETRATION (mils) ${ }^{l}$ FOR A TEST EXPOSURE IN ANHYDROUS AMMONIA :PLUS 0.148 SEAWATER AT $5^{\circ} \mathrm{C}^{4}$

\begin{tabular}{|c|c|c|c|c|c|}
\hline Material & $\begin{array}{l}\text { Period, } \\
\text { days } \\
\end{array}$ & $\begin{array}{l}\text { Crevice } \\
\text { Test.: } \\
0.26 \text { ifps }\end{array}$ & Velocity & $5.6 \mathrm{fps}$ & Pitting Observations 2,5 \\
\hline Al $3003-\mathrm{H} 14$ & .100 & .007 & .009 .009 & .012 .028 & $\begin{array}{l}\text { At all indicated velocities \& exposure periods, only } \\
\text { a very few incipient pits. }\end{array}$ \\
\hline Al $50.52-\mathrm{H} 32$ & $\begin{array}{l}10 \\
24\end{array}$ & .007 & .012 .012 & .008 .034. & $\begin{array}{l}\text { At } 2.5 \text { fps, a very few incipient pits at } 10 \text { days, } \\
\text { increasing to a few incipient pits and one small pit } \\
\text { at } 24 \text { days. At } 5.6 \text { fps., a few few incipient pits at } \\
10 \text { and } 24 \text { days. }\end{array}$ \\
\hline $\begin{array}{l}\text { Al } 50.52-\mathrm{H} 32 \\
\text { (treated) }\end{array}$ & $\begin{array}{l}1.0 \\
24\end{array}$ & .032 & .030 .027 & $\begin{array}{r}.029 \\
.024\end{array}$ & $\begin{array}{l}\text { At all indicated velocities \& exposure periods, only } \\
\text { a very few incipient pits. }\end{array}$ \\
\hline Al $5086-\mathrm{H} 32$ & $\begin{array}{l}10 \\
24\end{array}$ & .006 & .013 .018 & $\begin{array}{r}.020 \\
.044\end{array}$ & $\begin{array}{l}\text { A few incipient pits at all indicated velocities } \\
\text { exposures }\end{array}$ \\
\hline C.P. Titanium & $\begin{array}{l}10 \\
24\end{array}$ & W.G. ${ }^{3}$ & $\begin{array}{l}.0005 \\
.0001\end{array}$ & $\begin{array}{r}.0008 \\
.0001\end{array}$ & $\begin{array}{l}\text { At } 2.5 \text { fps, a very few incipient pits at } 10 \text { days, } \\
\text { increasing to a few incipient puts \& one small pit } \\
\text { at } 24 \text { days. } \\
\text { At } 5.6 \text { fps, a very few incipient at } 10 \& 24 \text { days. }\end{array}$ \\
\hline
\end{tabular}

1

Total Average Penetration corrected for losses occurring during post exposure cleaning.

2 Because of the small surface area of the coupons and the short period of exposure, pitting. data was based upon the following key:

Incipient pitting: Pits less than 0.5 mils deep, discernable as pits under $25 x$ magnification.

Small pits: Pits 1.0-0.5 mils ceep, discernable as pit under 10x magnification and visible to naked eye.

Pits: Pits 1-2 mils deep (unless otherwise indicated), readily visible as pits to naked eye.

Very Few: Less than 5/sq. in.

Few: $\quad 5-10 / \mathrm{sq}$. in.

Several: 10-15/sq. in.

Numerous: More than $15 \%$ sq. in.

3 Weight Gain.

4 Water content measured $0.6 \%$ for 10 days \& $0.14 \%$ for final 14 days.

5 Max. pit depth $0.5-1.0 \mathrm{mil}$ on any specimen. 
TABLE IX-32

CORROSION DATA FOR CREVICE CORROSICN TEST ANHIDROUS AMMONIA PLUS 0.14\% SEAWATER AT 5० C FOR 24 DAYS ${ }^{\circ}$

\begin{tabular}{|c|c|c|c|}
\hline A110y & $\begin{array}{r}\text { Corrosion } \\
(\mathrm{mpy})\end{array}$ & Rate & $\begin{array}{l}\text { Crevice Attark } \\
\text { and Pitting observations }{ }^{2}\end{array}$ \\
\hline Al $3003 \mathrm{~F}-14$ & $.00 ?$ & & $\begin{array}{l}\text { A few incipient fits \& one small } \\
\text { pit on the specimen surface. No } \\
\text { crevice attack. }\end{array}$ \\
\hline Al $5052 \mathrm{~F}-32$ & $.00 ?$ & & A very few incipient pits. \\
\hline $\begin{array}{l}\text { Al } 5052 \mathrm{~F}-32 \\
\text { (Treateci) }\end{array}$ & .032 & & $\begin{array}{l}\text { A very few incipient pits \& one } \\
\text { pit on surface. }\end{array}$ \\
\hline Al $5036 \mathrm{H}-32$ & .006 & & $\begin{array}{l}\text { A few incipient fits \& one small } \\
\text { pit on surface. }\end{array}$ \\
\hline C.P. Titanium & W. G. ${ }^{3}$ & & A very few incipient pits. \\
\hline
\end{tabular}

1 Water content was $0.6 \%$ for 10 days and $0.14 \%$ for 14 days.

2 Max. pit depth was $0.5-1.0 \mathrm{mil}$ on any specimer..

3 Weight Gain 


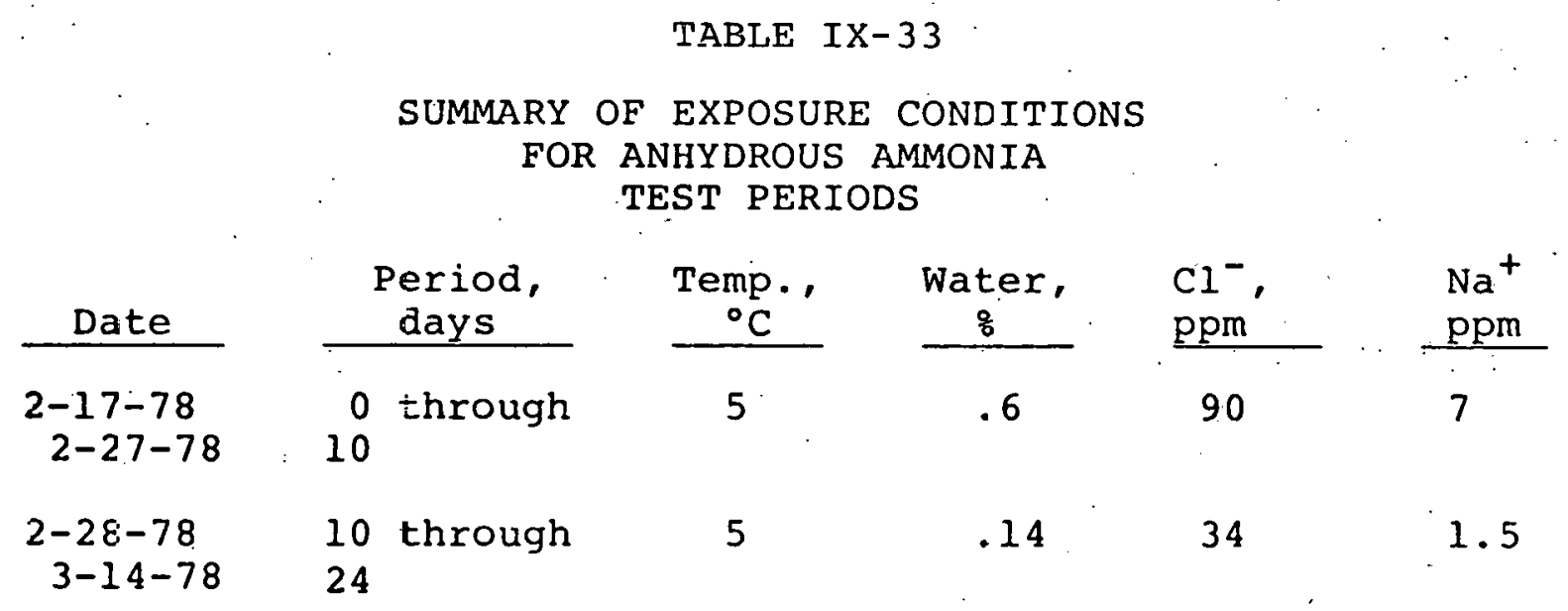


TABLE IX-34

CCRROSION DATA FOR TEST

$5^{\circ} \mathrm{C}$ Anhycrous Ammonia $+1.12 \%$ Seawater

Total Arrerage Penetration (rils) ${ }^{1}$ and

(Max. Pit Depth, mils)

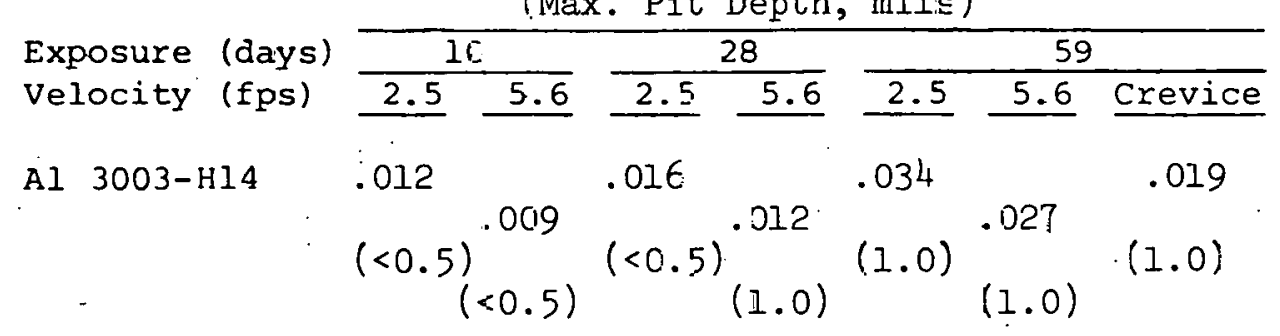

Pitting Observations 2,4

At $2.5 \mathrm{fps}$, surface discoloration indicative of surface attack was observed at 10 days.

In addition, a few incipient pits were observed at 28 days and one small pit was observed at 59 days.

At $5.6 \mathrm{fps}$, surface attack was observed at 10 days and at 28 ard 59 days a few incipient pits and one small pit were observed.

One small pit was cbserved at the crevice of the crevice specimen.

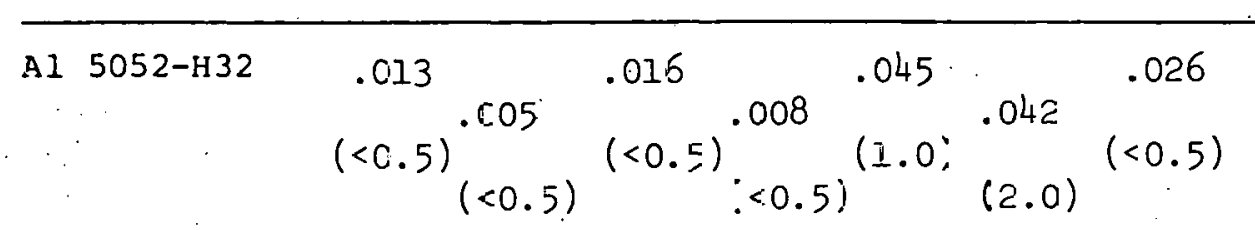

At 2.5 fps, sone surface discoloration indicative of sur incipient pits were observed at 10 days, with the addition of one small pit observed at 59 days.

At $5.6 \mathrm{fps}$, scme surface attack was observed at 10 aidd 23 days, and a few incipient pits, =wo small pits, and 1 pit ivere observed at 59 days.

No crevice corrosion was observed.

\begin{tabular}{|c|c|c|c|c|c|}
\hline $\begin{array}{l}\text { AI } 5052-H 32 \\
\text { (Treated) }\end{array}$ & ${ }_{(<0.5)^{.023}}^{.027}$ & $\begin{array}{l}.025 \\
(<0.5)\end{array}$ & $\begin{array}{l}.027 \\
(<0.5)\end{array}$ & $\begin{array}{l}.030 \\
(<0.5)\end{array}$ & )$_{(<0.5)^{.029}(1.0)}^{.022}$ \\
\hline
\end{tabular}

At $2.5 \mathrm{fps}$ anc $5.6 \mathrm{Fps}$, a very few incipient pits were observec'.

A few incipient fits and 1 small pit were were observed at the crevice on the crevice specimen. 


\begin{tabular}{|c|c|c|c|c|c|c|c|}
\hline & & & & & \multirow{2}{*}{\multicolumn{3}{|c|}{59}} \\
\hline \multirow{2}{*}{$\begin{array}{l}\text { Exposure (days) } \\
\text { Velocity (fps) }\end{array}$} & \multicolumn{2}{|c|}{10} & \multicolumn{2}{|c|}{28} & & & \\
\hline & 2.5 & 5.6 & 2.5 & 5.6 & 2.5 & 5.6 & Crevice \\
\hline A.1 $5086-\mathrm{H} 32$ & .012 & & .017 & & .059 & & .030 \\
\hline & $(<0.5)$ & $\begin{array}{l}.006 \\
(<0.5)\end{array}$ & $(<0.5)$ & $\begin{array}{l}.012 \\
(1.0)\end{array}$ & $(<0.5$ & $\begin{array}{l}.069 \\
(1.0)\end{array}$ & $(1.0)$ \\
\hline
\end{tabular}

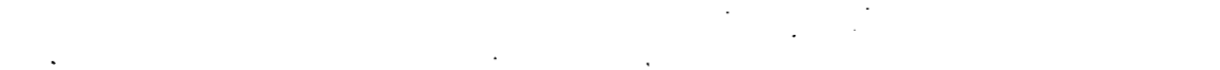

\section{Pitting Observations 2,4}

At 2.5 fps, some surface discoloration indicative of surface attack and a few incipient pits were observed.

At $5.6 \mathrm{fps}$, some surface attack and a few incipient pits were observed at 10 days, and an additional two small pits were. observed at 28 and 59 days.

On the crevice specimen, several incipient pits and two small pits were observed at locations independent of the crevice.

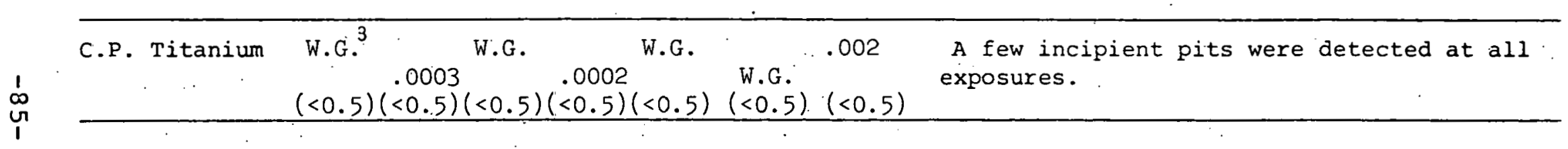

1. Total Average Penetration correctéd for losses occurring during post exposure cleaning.

2 Because of the small surface area of the coupons and the short period of exposure, pitting data was based upor the following key:

Incipient fitting: Pits less than 0.5 mils deep, discernable as pits under $25 x$ magnification. Small pits: Pits $1.0-0.5 \mathrm{mils}$ deep, discernable as pits under 10x magnification and visible to naked eye.

Pits: Pits 1-2 mils deep (ur.less otherwise indicated), readily visible as pits to maked eye.

Very Few: Less than 5/sq. ir..

Few: $\quad 5-10 / \mathrm{sq}$. in.

Several: 10-15/sq. in.

Numerous: More than 15/sq. in.

3 Weight Gain.

4 Max. pit depth $0.5-1.0 \mathrm{mil}$ on any specimen. 
TAELE IX-35

SUMMARY OF EXPOSURE CONDITIONS

FOR ANHYDFOUS AMMONIA + $1 \%$ SEAWATER TEST PERIODS

\begin{tabular}{|c|c|c|c|c|c|}
\hline Date & $\begin{array}{c}\text { Period, } \\
\text { days }\end{array}$ & $\begin{array}{c}\text { Temp. } \\
{ }^{\circ} \mathrm{C} \\
\end{array}$ & $\begin{array}{c}\text { Water, } \\
8 \\
\end{array}$ & $\begin{array}{l}\mathrm{Cl}^{-} \\
\mathrm{ppm}\end{array}$ & $\begin{array}{l}\mathrm{Na}^{+} \\
\mathrm{ppm} \\
\end{array}$ \\
\hline $\begin{array}{c}3-17-78 \\
3-28-78\end{array}$ & $\begin{array}{l}0 \text { through } \\
10\end{array}$ & 5 & 1.03 & 2.6 & 65 \\
\hline $\begin{array}{l}3-30-78 \\
4-17-78\end{array}$ & $\begin{array}{l}10 \text { through } \\
2 \mathrm{~B}\end{array}$ & 5 & 1.03 & 250 & 60 \\
\hline $\begin{array}{c}4-19-78 \\
5-19-78\end{array}$ & $\begin{array}{l}28 \text { through } \\
59\end{array}$ & 5. & 1.12 & 229 & 70 \\
\hline
\end{tabular}


TABLE IX-36

CORROSION DATA FOR TEST

$5^{\mathrm{C} C}$ Anhydrous Ammonia $+2.5 \%$ Seawater

Total Average Penetration (mils) $)^{1}$ and (Max. Pit Depth, mils)

\begin{tabular}{|c|c|c|c|c|c|c|c|}
\hline \multirow{2}{*}{$\begin{array}{l}\text { Exposure (days) } \\
\text { Velocity (fps) }\end{array}$} & \multicolumn{2}{|c|}{9} & \multicolumn{2}{|c|}{30} & \multicolumn{3}{|c|}{53} \\
\hline & 2.5 & 5.6 & 2.5 & 5.6 & 2.5 & 5.6 & Crevice \\
\hline Al3003-H14 & $\begin{array}{l}.002 \\
(<0.5)\end{array}$ & $\begin{array}{r}.003 \\
\text { (1) }\end{array}$ & $\begin{array}{l}.004 \\
(<1) .5)\end{array}$ & $\begin{array}{l}.005 \\
1<0.5\end{array}$ & $\begin{array}{l}.038 \\
(<0.5)\end{array}$ & $\begin{array}{l}.044 \\
1<0.5\end{array}$ & $\begin{array}{l}.042 \\
(<0.5)\end{array}$ \\
\hline
\end{tabular}

Pitting Observations 2,4

At 2.5 fps, a very few incipient pits were observed at 9 and 30 days increasing to a few incipient pits at 53 days.

At 5.6 fps, a very few incipient pits were observed with two small pits present at 9 days.

on the crevice specimen, a very few incipient pits were noted.

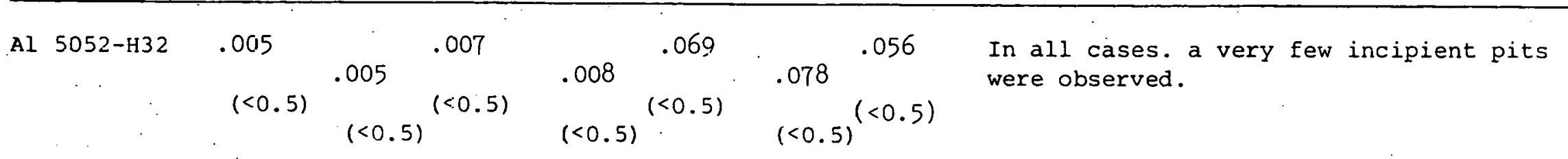

\begin{tabular}{|c|c|c|c|c|c|c|}
\hline $\begin{array}{l}\text { Al 5052-H32 } \\
\text { (frieated) }\end{array}$ & $\begin{array}{l}.022 \\
(<0.5)\end{array}$ & $\begin{array}{l}.027 \\
.<0.5\end{array}$ & $\begin{array}{l}.024 \\
(=0.5)\end{array}$ & $\begin{array}{l}.026 \\
1<0.5\end{array}$ & $\begin{array}{l}.031 \\
(<0.5)\end{array}$ & ${ }_{(<0.5)^{.0}}^{.028}(<0.5)$ \\
\hline
\end{tabular}

In all cases, a very few incipient pits were observed.

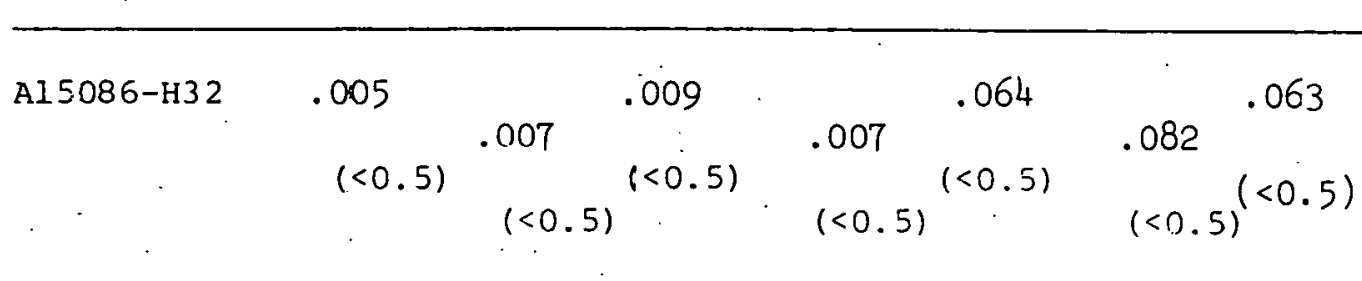

In all cases, a very few incipient pits were observed.

(Continued) 


\section{Table IX-36 continued}

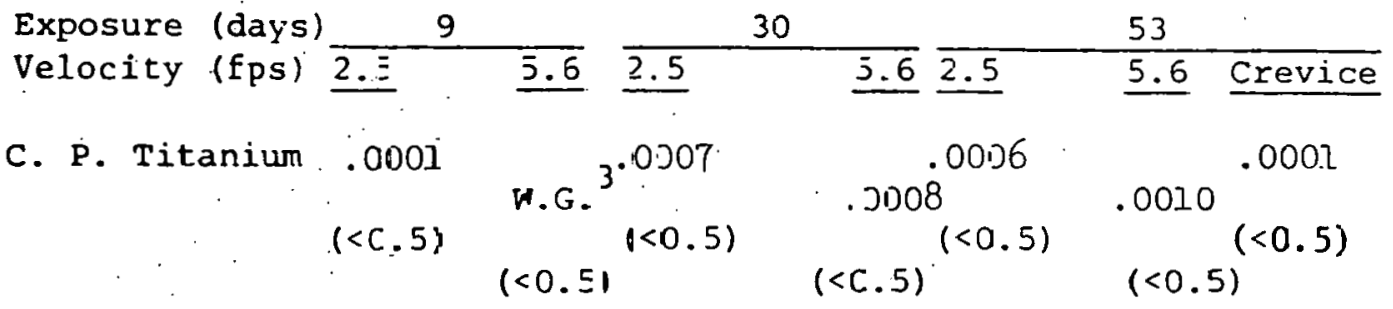

Pitting Observations 2,4 .

At $2.5 \mathrm{fps}$ and $5.6 \mathrm{fps}$, several incipient pits Nere observed.

A few incipient pits were observed on the crevize specimen.

1 Total Average Penetration corrected far losses occurring during post exposure cleaning.

2 Because of the small surf $\equiv c$ e area of the coupons ard the short period of exposure, pitting data was based upon the following key:

Incipient pitting: Pits less than $0.5 \mathrm{mils}$ deep, discernable as pits under $25 x$ magnification. Small pits: Pits 1.0-0.5 rils deep, discernable as pits under lox magnification and visible to naked eye.

Pits: Pits 1-2 nils deep (unless otherwise indicated), readily visitle as pits to naked eye. Very Few: Less than 5/sq. in.

Few: $\quad 5-10 / \mathrm{sq}$. in.

Several: $10-15 / \mathrm{sq}$. in.

3 Numerous:

4 Max. pit depth $0.5-1.0 \mathrm{mil}$ on any specimen. 
TABLE IX- 37

SUMMARY OF EXPOSURE CONDITIONS

FOR ANHYDROUS AMMONIA

PLUS $2.5 \%$ SEAWATER

\begin{tabular}{|c|c|c|c|c|}
\hline $\begin{array}{l}\text { Period, } \\
\text { Days } \\
\end{array}$ & $\begin{array}{c}\text { Temp. } \\
{ }^{\circ} \mathrm{C} \\
\end{array}$ & $\begin{array}{c}\text { Water, } 1 \\
\quad \\
\end{array}$ & $\begin{array}{l}\mathrm{Cl}-\text {, } \\
\text { ppm }\end{array}$ & $\begin{array}{l}\mathrm{Nat} \\
\text { ppm }\end{array}$ \\
\hline $\begin{array}{l}0 \text { through } \\
10\end{array}$ & $5^{\circ}$ & 7.7 & 406 & 191 \\
\hline $\begin{array}{l}9 \text { through } \\
30\end{array}$ & $5^{\circ}$ & 3.7 & 536 & 270 \\
\hline $\begin{array}{l}3.0 \text { through } \\
53\end{array}$ & $5^{\circ}$ & 3.3 & 614 & 287 \\
\hline
\end{tabular}

Actual water analysis. A known $2.5 \%$ seawater initially added to anhydrous $\mathrm{NH}_{3}$. 
TABLE IX-38

CLEANING SOLUTION SCREENING

Test Results on Al 3UU3-HL (Fouled).

Solution

\section{Mild}

$1 / 2 \%$ wt. hydroger. paroxide

12 hr. exposure

Deionized water rinse

II. Mild

5\% wt. calcium hypochlorite

(substitute $7.7 \%$ HTH dry chlorine

for pool use)

1/2\% wt. sodium melasilicate

At ambient temperatire

12-hr. exposure

Deionized water rinse

III. Alkaline

5\% wt. sodium sarbonate in deionized water

5\% wt. monosodium phosphate

5\% wt. trisodidm phosphate

$0.5 \%$ wt. sodium metasilicate

12 hrs. at ambient temperature

12-hr. exposure

Deionized water rinse

\section{Harsh-Acid}

$10 \%$ vol. concentration $\mathrm{H}_{2} \mathrm{SO}_{4}$ in deionized water

$2 \%$ wt. chromic acil

At ambient temperature

4-hr. exposure

Deionized water rinse
Results

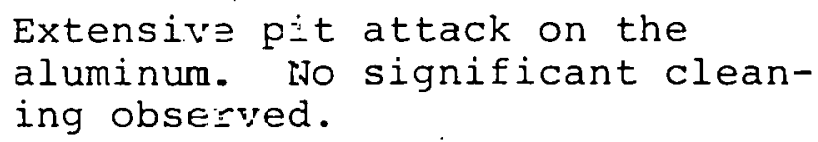

This solution, although filtered to remore inert material, left a white powcer residue on a clean aluminum surface. Secondary choice as a cleaning solution.

No observed effect.

Clean metal surface: 
TABIE IX-39

CLEANING TESTS: CORROSION SUMMARY FINAL INTERVAL CORROSION RATE (mPY) ${ }^{1,2}$

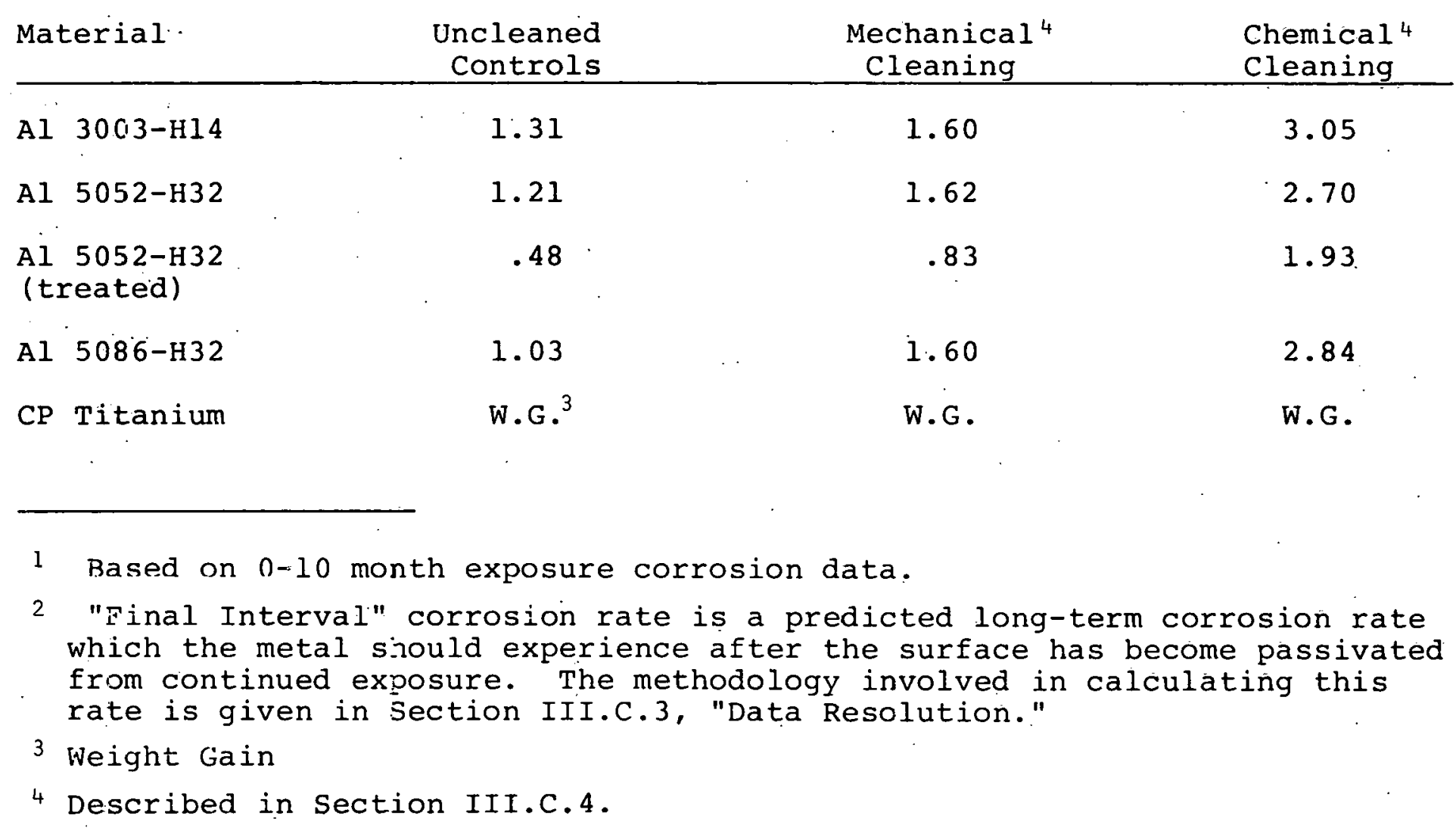


TABLE IX-40

CLEANING TISTS: CORROSICN SUMMARY

Total Average Penetration (mils)

\begin{tabular}{lccc}
\hline $\begin{array}{l}\text { Specimen } \\
\text { Treatment }\end{array}$ & $\begin{array}{c}\text { Uncleaned } \\
\text { Controls }\end{array}$ & $\begin{array}{c}\text { Mechanical } \\
\text { Cleaning }\end{array}$ & $\begin{array}{c}\text { Chemical } \\
\text { Cleaning }\end{array}$ \\
\hline $\begin{array}{l}\text { Average Exposure } \\
\text { (days) }\end{array}$ & 319 & 313 & 313 \\
\hline Material & & & 2.62 \\
\hline Al 3003-H14 & 1.14 & 1.37 & 2.32 \\
Al 5052-H32 & 1.06 & 1.39 & 1.66 \\
Al 5052-H32 & .42 & .71 & 2.43 \\
(Treated! & .90 & 1.37 & W.G. \\
Al 5086-H32 & W.G.2 & W.G. & \\
CP Titanium & & &
\end{tabular}

1 Described in section III.C. A.

2 Weight Gain 


\section{TABLE IX- 41}

\section{CLEANING TESTS}

AMBIENT TEMPERATURE UNFILTERED SEANATER
Alloy
Cleaning 1
Period (months)
Cleaning and Corrosion
Group 1 Group 2
observations

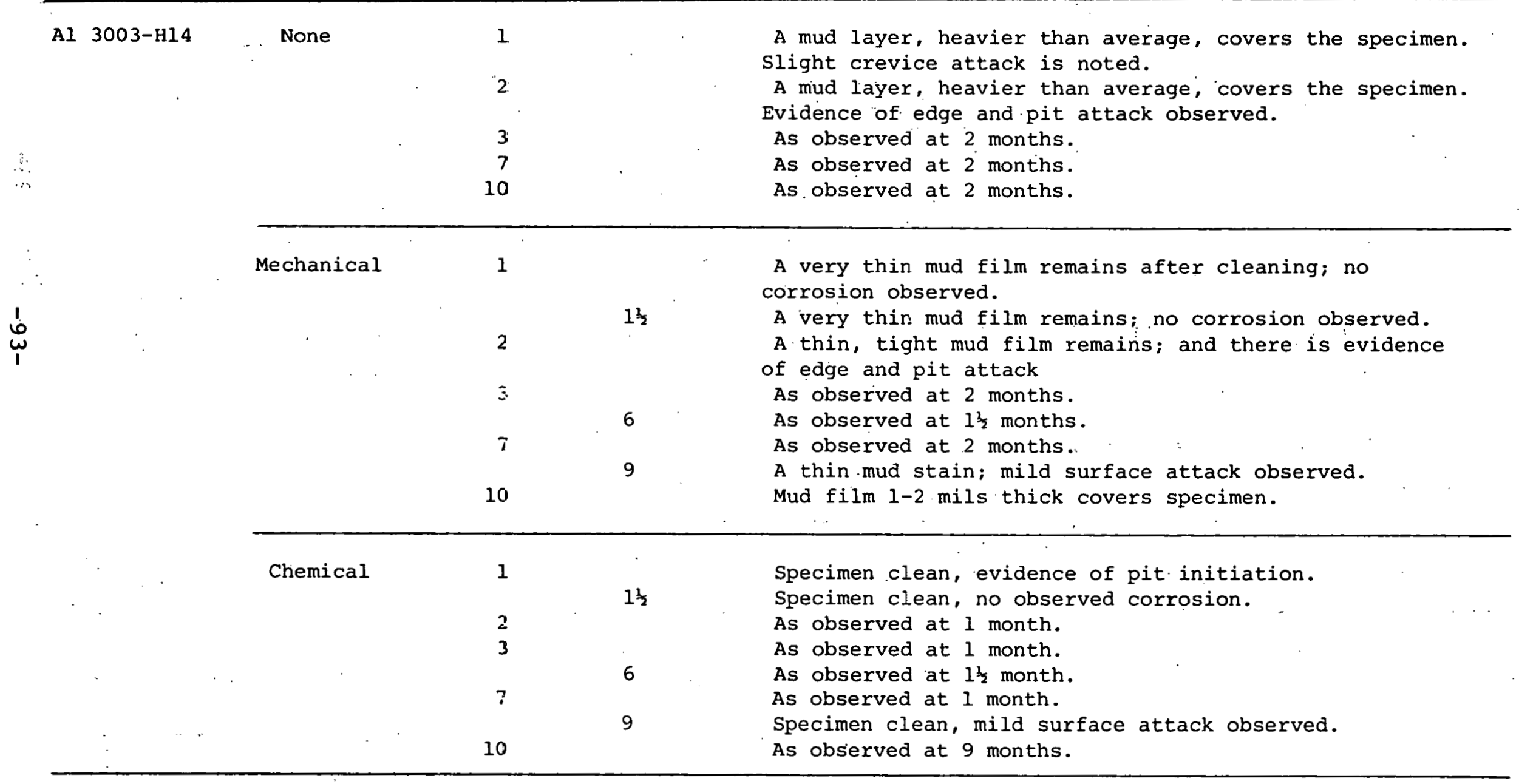

1 Described in Section III.C. 4. 
Table IX-4I contirued

Alloy Cleaning $\quad \begin{gathered}\text { Period (months) } \\ \text { Group } 1 \text { Grodp } 2\end{gathered} \quad \begin{gathered}\text { Cleaning and Corrosion } \\ \text { Observations }\end{gathered}$

\begin{tabular}{|c|c|c|c|}
\hline Al 5052-H32 & None & $\begin{array}{c}2 \\
3 \\
7 \\
10\end{array}$ & $\begin{array}{l}\text { A slightly. heavier mud layer is present, and slight } \\
\text { crevice attack is present. } \\
\text { A mud layer, heaviest of any metal, is present, and } \\
\text { slight crevice attack is present. } \\
\text { As observed at } 2 \text { months. } \\
\text { Average fouling layer present; evidence of slight } \\
\text { pitting present. } \\
\text { As at } 7 \text { months. }\end{array}$ \\
\hline
\end{tabular}

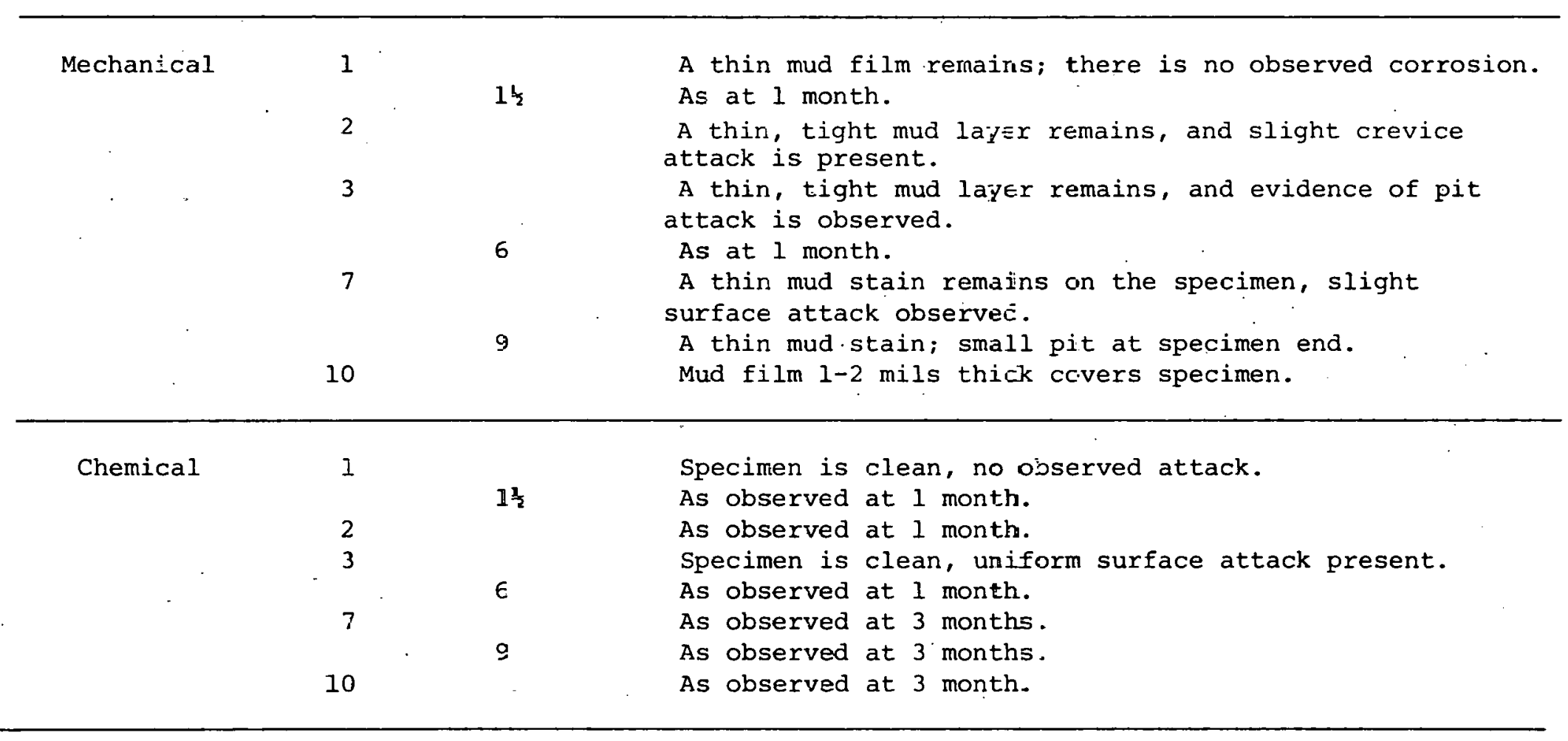

(continued) 
Alloy clearing

Period (months)

Groip 1 Group 2
Cleaning and Corrosion

observations

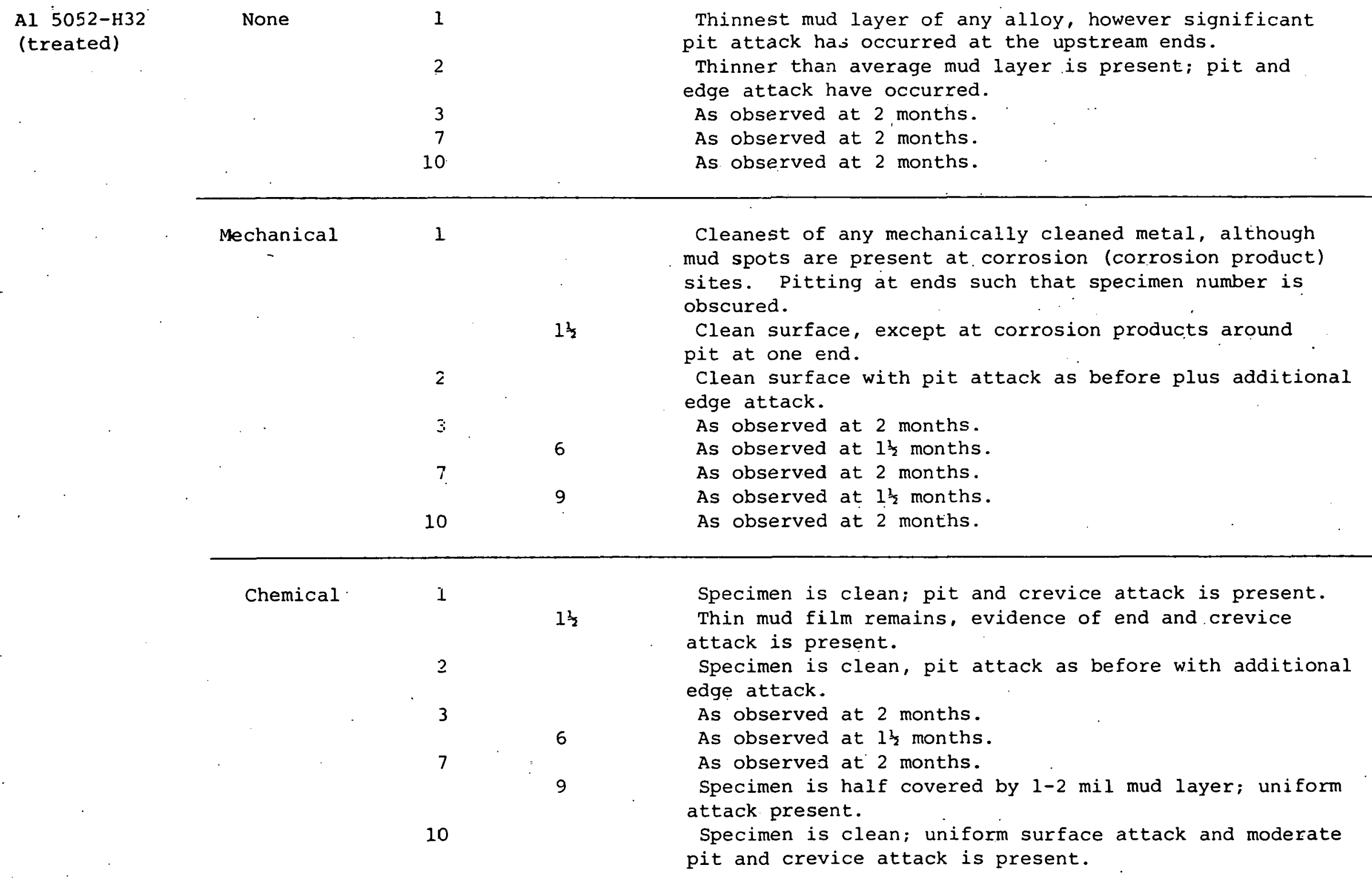




\section{Table IX-41 continued}

\begin{tabular}{|c|c|c|c|}
\hline & ing & $\begin{array}{l}\text { Period (months } \\
\text { Group 1 Gro:sp }\end{array}$ & $\begin{array}{c}\text { Cleaning and Corrosion } \\
\text { Observations. }\end{array}$ \\
\hline
\end{tabular}

\begin{tabular}{|c|c|c|c|c|}
\hline \multirow[t]{3}{*}{ A1 $5086-\mathrm{H} 32$} & None & $\begin{array}{r}1 \\
2 \\
3 \\
7 \\
10\end{array}$ & & $\begin{array}{l}\text { A mud layer covers the specimen, and no evidence of } \\
\text { corrosion is apparent. } \\
\text { As observed at } 1 \text { morti. } \\
\text { As observed at } 1 \text { montin. } \\
\text { As observed at } 1 \text { month. } \\
\text { As observed at } 1 \text { month. }\end{array}$ \\
\hline & $\begin{array}{l}\text { Mechanical } \\
:\end{array}$ & $\begin{array}{l}1 \\
2 \\
3 \\
7 \\
10\end{array}$ & $1 \frac{1}{2}$ & $\begin{array}{l}\text { A thin mud film remains; there is no observed corrosion. } \\
\text { As observed at } 1 \text { month. } \\
\text { As observed at } 1 \text { month. } \\
\text { As observed at } 1 \text { month. } \\
\text { As observed at } 1 \text { month. } \\
\text { A thin mud film remair.s, uniform corrosion attack evident. } \\
\text { As observed at } 7 \text { montrs. } \\
\text { Mud deposits } 1-2 \text { mils thick remain on specimen. }\end{array}$ \\
\hline & Chemical & $\begin{array}{r}1 \\
2 \\
3 \\
7 \\
7\end{array}$ & $\begin{array}{l}6 \\
9\end{array}$ & $\begin{array}{l}\text { Specimen is clean; no corrosion is observed. } \\
\text { As observed at } 1 \text { mon=h. } \\
\text { As observed at } 1 \text { mon=h. } \\
\text { As observed at } 1 \text { mon=h. } \\
\text { As observed at } 1 \text { mon=h. } \\
\text { Specimen is clean; uniform. corrosion is apparent. } \\
\text { As observed at } 7 \text { months. } \\
\text { As observed at } 7 \text { months. }\end{array}$ \\
\hline CP Titanium & None & $\begin{array}{r}1 \\
2 \\
3 \\
7 \\
10\end{array}$ & & $\begin{array}{l}\text { A mud layer, thinnner than average, is present, and } \\
\text { no corrosion is observed. } \\
\text { As observed at } 1 \text { month. } \\
\text { As observed at } 1 \text { month. } \\
\text { As observed at } 1 \text { month. } \\
\text { As observed at } 1 \text { month. }\end{array}$ \\
\hline
\end{tabular}


Table IX-4I continued

Alloy

\section{Cleaning}

Period (months)

Group 1 Group 2

Cleaning and corrosion

Observations

\begin{tabular}{|c|c|c|c|c|}
\hline P Titanium & Mechanical & $\begin{array}{c}7 \\
10\end{array}$ & 6 & $\begin{array}{l}\text { A very thin mud film remains; there is no observed } \\
\text { corrosion. } \\
\text { Surface is clean, no observed corrosion. } \\
\text { As observed at } 1 \text { month. } \\
\text { As observed at } 1 \text { month. } \\
\text { Some mud remaining after cleaning, although specimen } \\
\text { is predominately clean. No evidence of corrosion. } \\
\text { As observed at } 6 \text { months. } \\
\text { As observed at } 6 \text { months. } \\
\text { As observed at } 6 \text { months. }\end{array}$ \\
\hline. & Chemical & $\begin{array}{c}7 \\
10\end{array}$ & $\begin{array}{l}6 \\
9\end{array}$ & $\begin{array}{l}\text { Specimen is clean, no observed corrosion. } \\
\text { A very thin mud layer remains which is easily removed } \\
\text { by hand contact. No evidence of corrosion. } \\
\text { As observed at } 1 \frac{1}{2} \text { months. } \\
\text { As observed at } l^{\frac{1}{2}} \text { months. } \\
\text { As observed at } l_{\frac{1}{2}}^{\frac{1}{2}} \text { months. } \\
\text { As observed at } 1 \frac{1}{2} \text { months. } \\
\text { Mud layer } w 1 \frac{1}{2} \text { mils thick covers specimen. } \\
\text { Mud layer } \sim \text { l mil thick covers specimen. }\end{array}$ \\
\hline
\end{tabular}


Appendix B

Equipment and Scale Photographs 


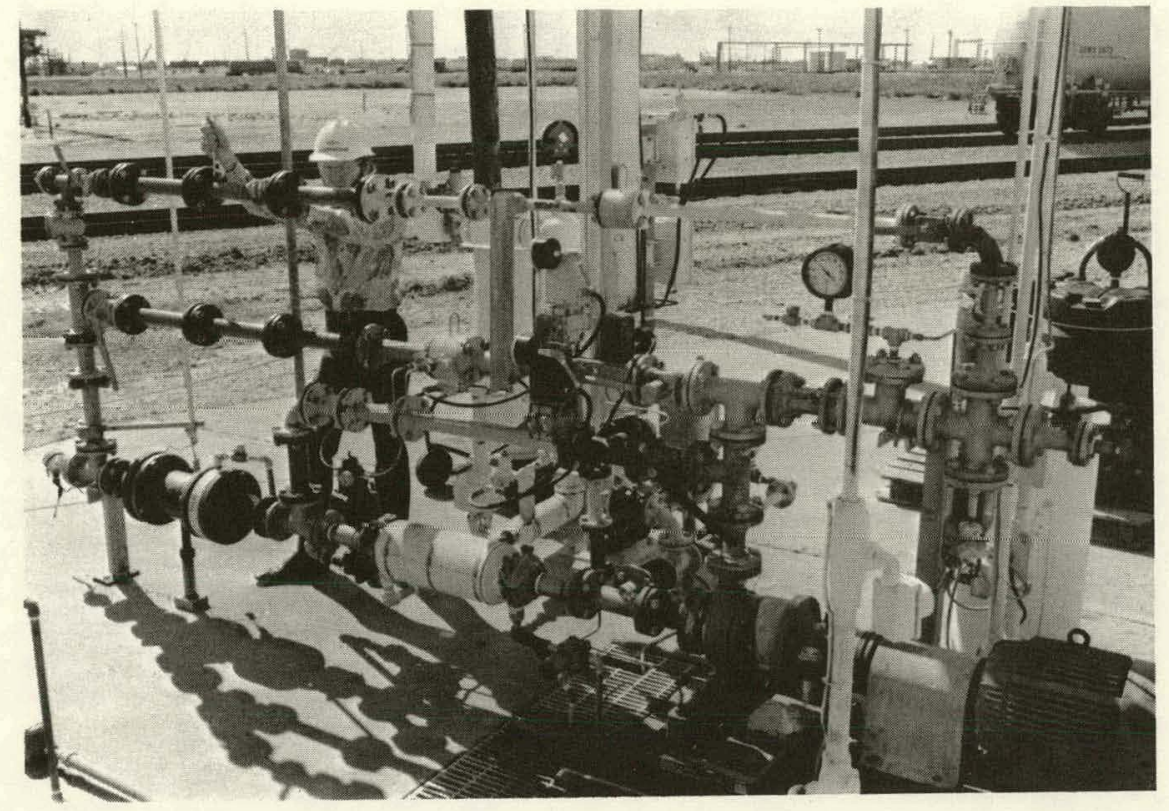

Figure IX-I

TEST UNIT 1: SEAWATER MIXED WITH AMMONIA AT $30^{\circ} \mathrm{C}$ 


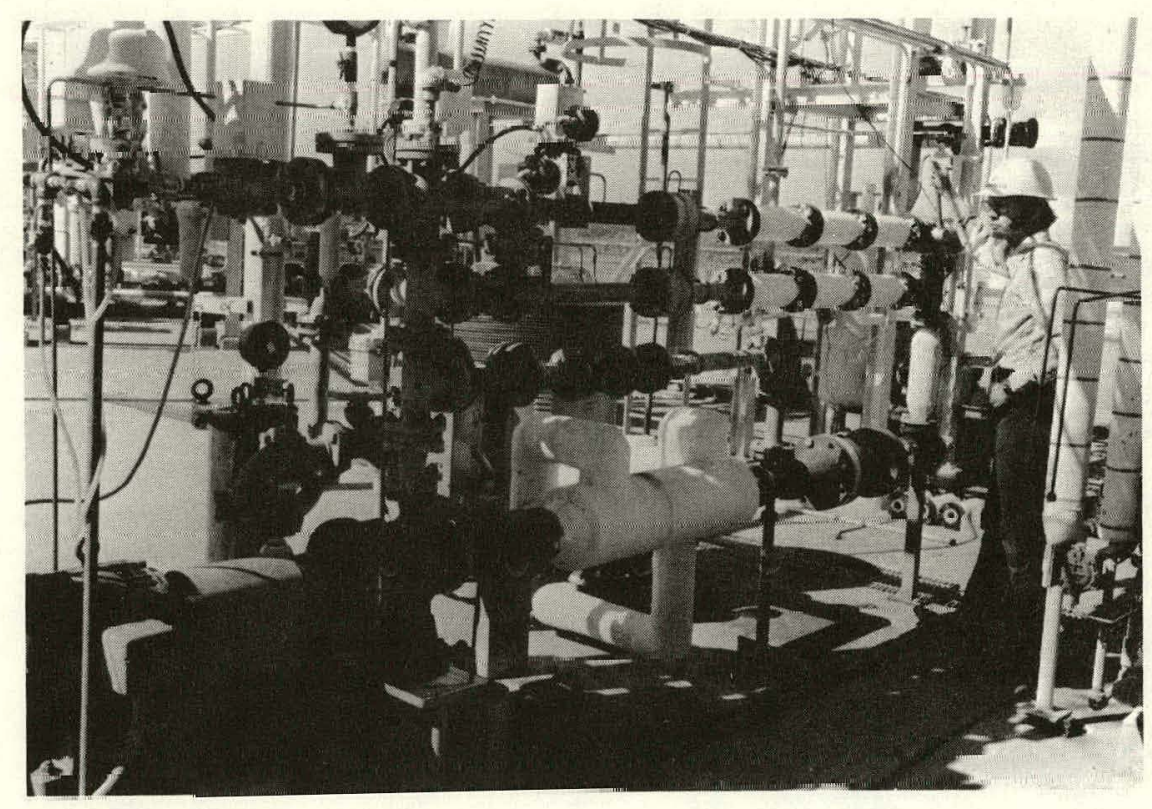

Figure IX-2

TES'L' UNL'L' $2:$ SEAWATER MIXFN WTTH AMMONIA $\Lambda T 5^{\circ} \mathrm{C}$ 


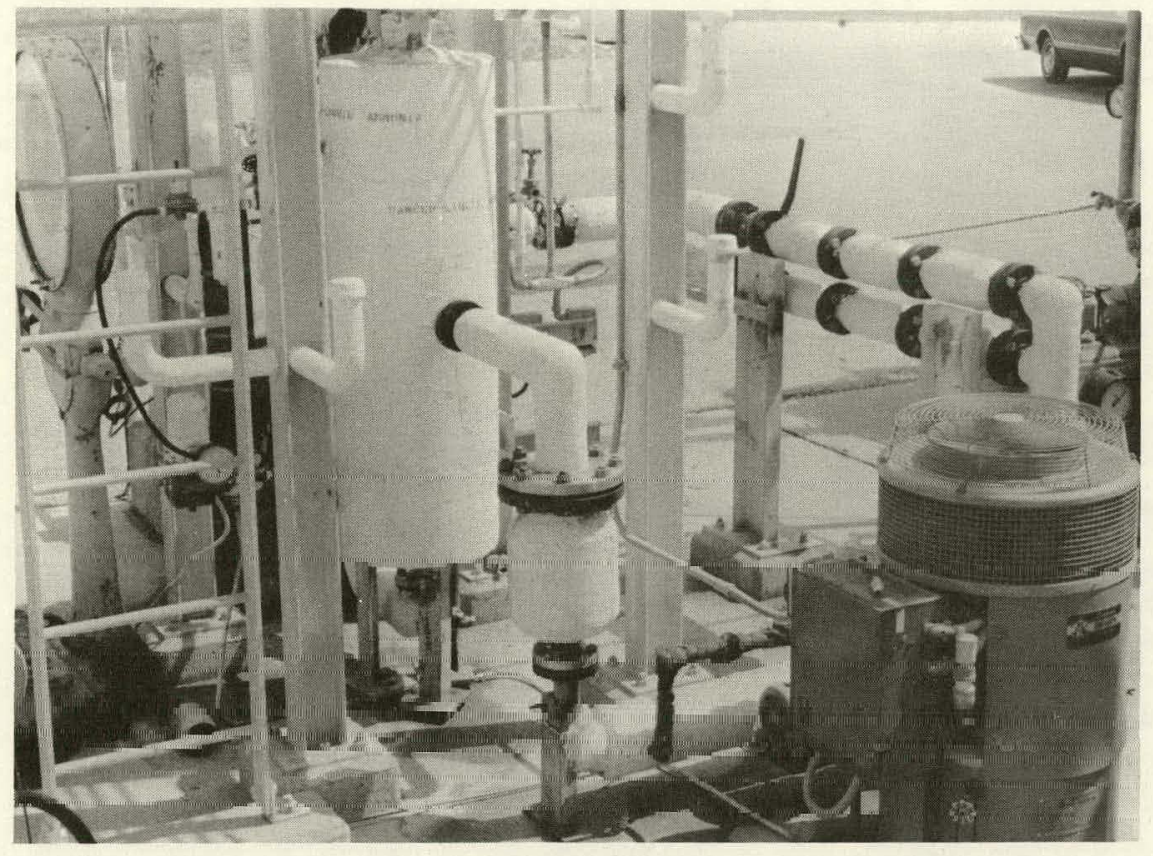

Figure IX-3

TEST UNIT 3: LIQUID ANHYDROUS AMMONIA

MIXED WITH SEAWA'IER

$\mathrm{AT} 5^{\circ} \mathrm{C}$ 


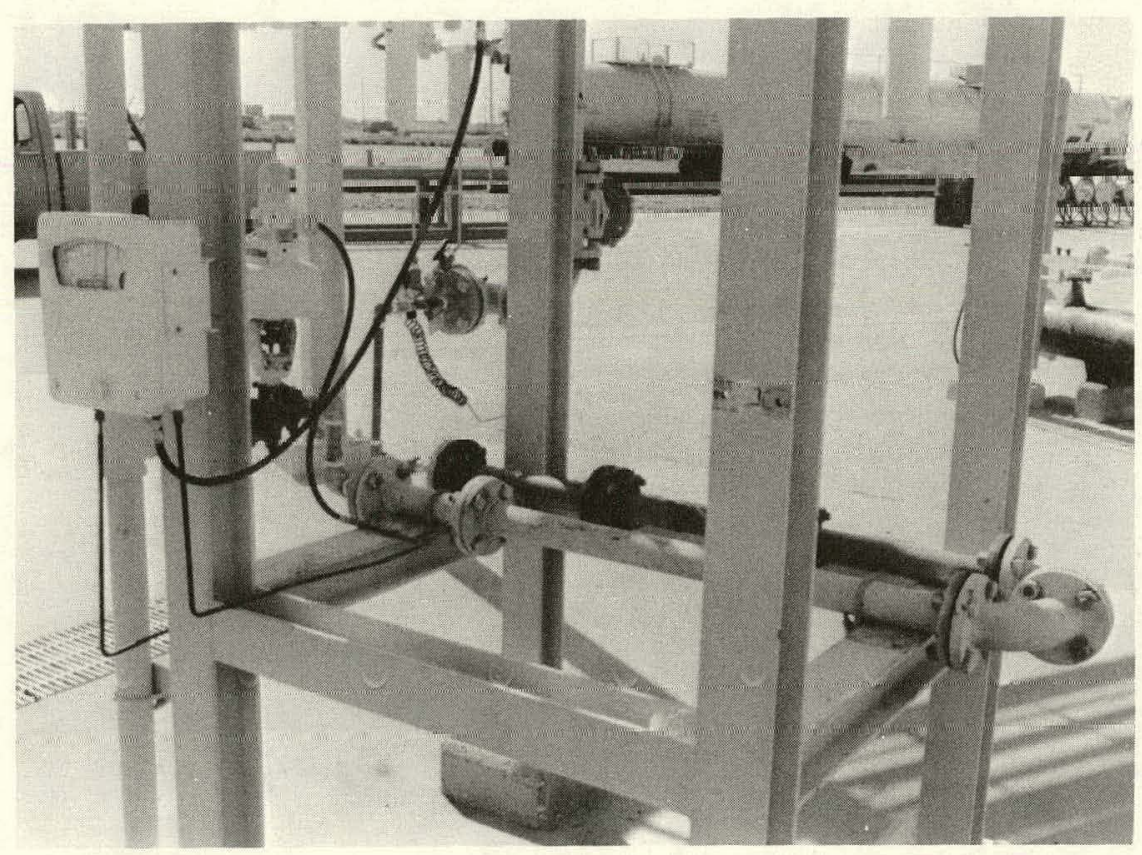

Figure IX-4

TEST UNIT 4: ONCE THROUGH AMBIENT TEMPERATURE SEAWATER SYSTEM FOR CLEANING TEST AND SEAWATER CORROSION CONTROLS 


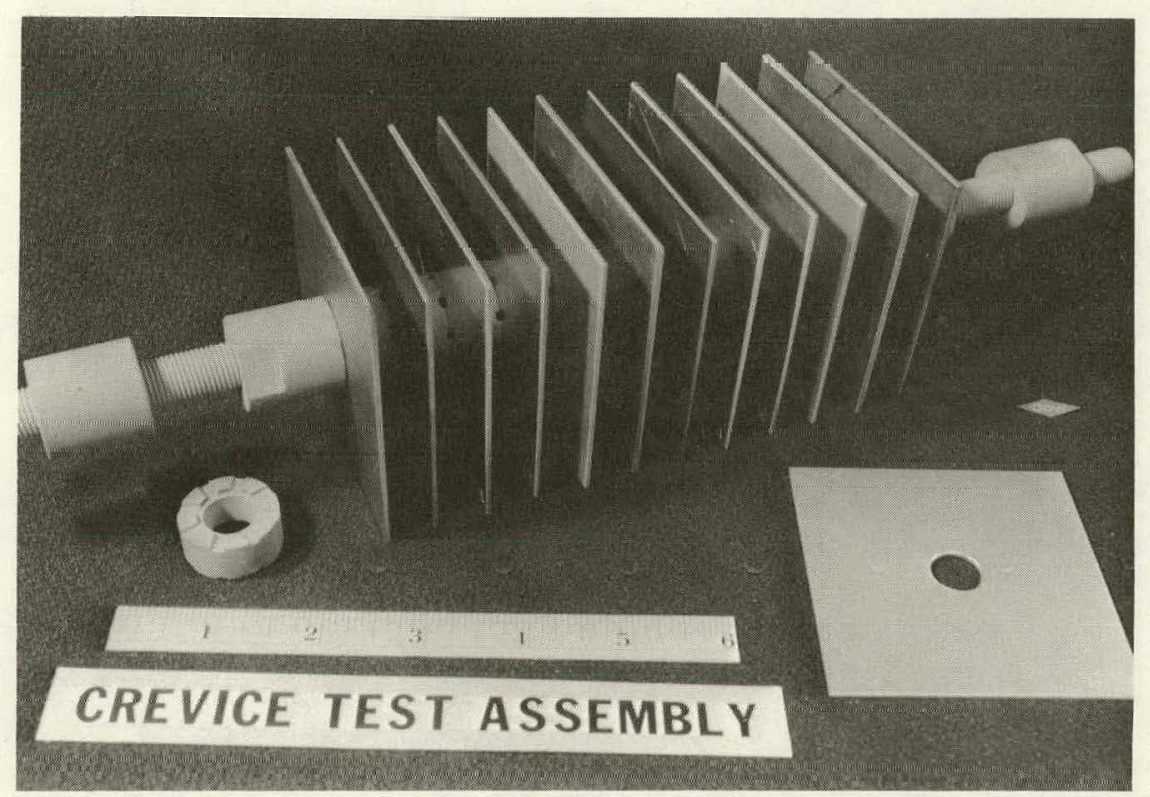

Figure IX-5

CREVICE CORROSION SPECIMEN ASSEMBLY 


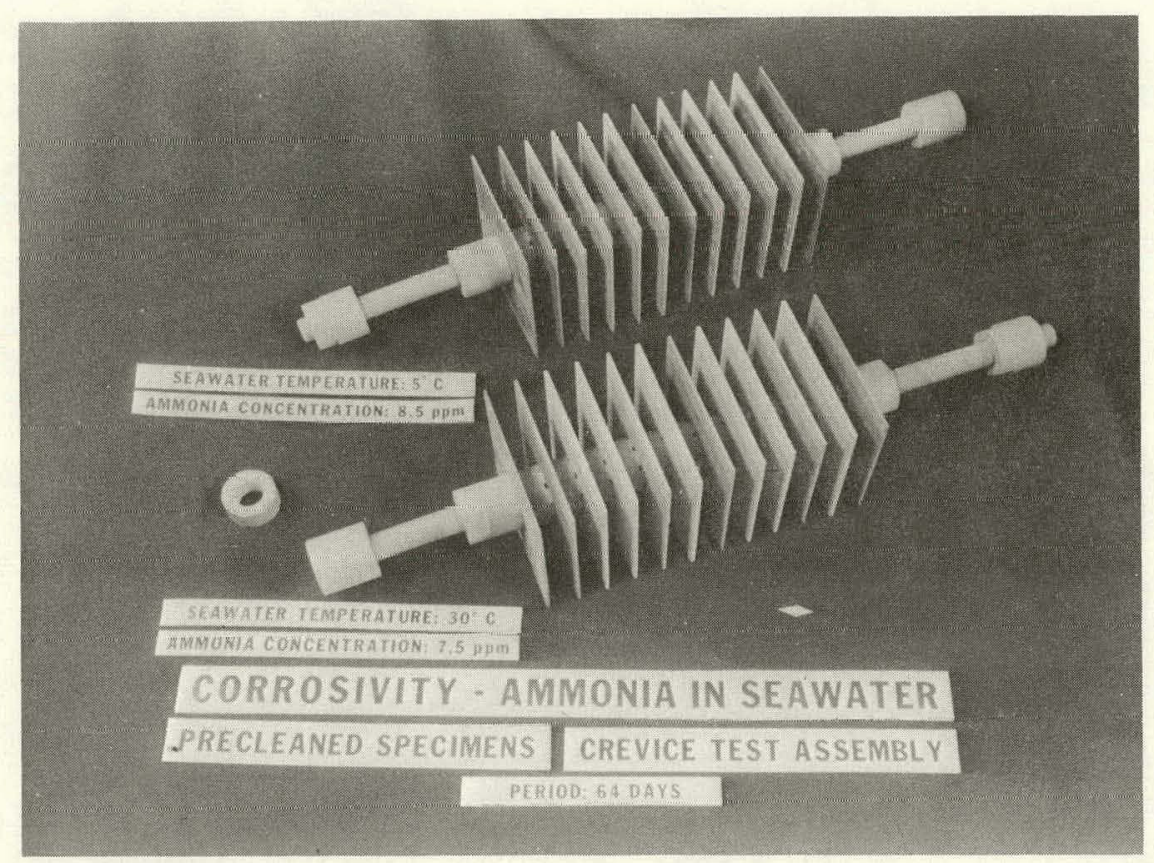

Figure IX-6

FOULING ON CREVICE TEST ASSEMBLY

8 ppm AMMONIA IN SEAWATER AT $5^{\circ} \mathrm{C}$ and $30^{\circ} \mathrm{C}$ 


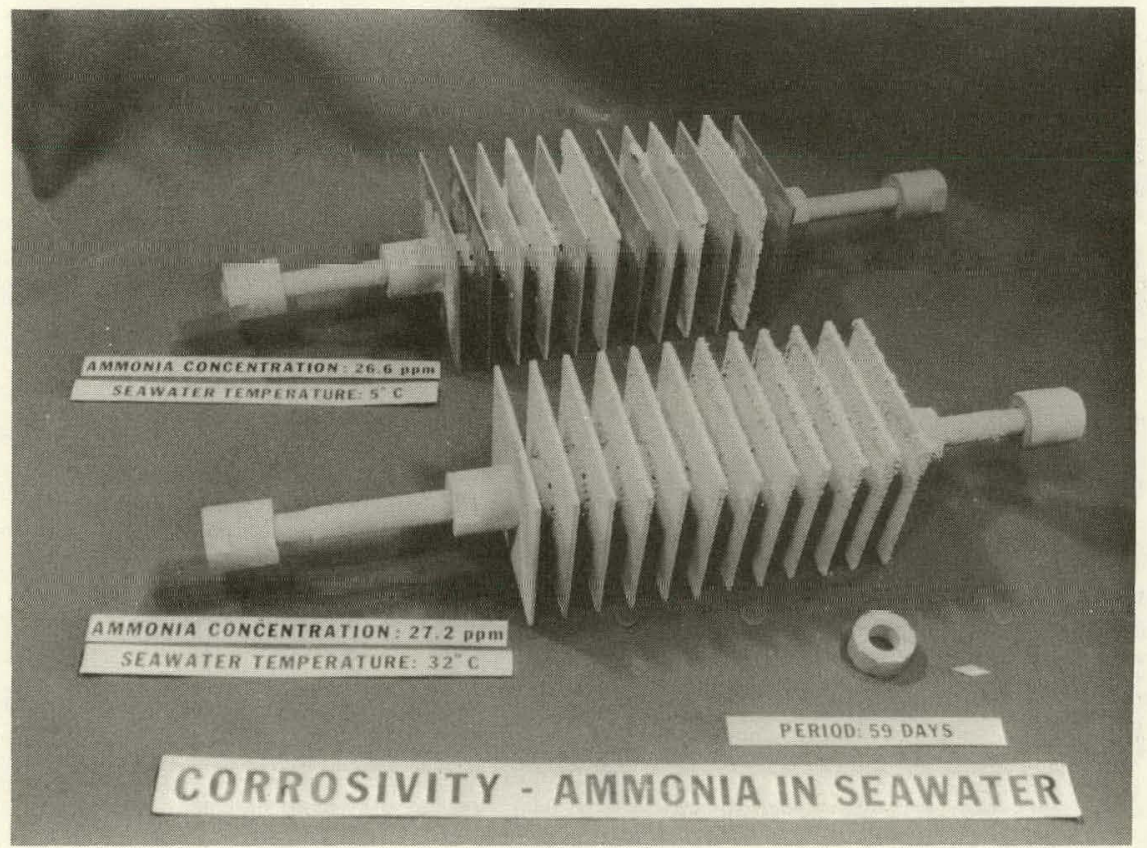

Figure IX-7

SCALE FORMATION ON CREVICE TEST ASSEMBLY $30 \mathrm{ppm}$ AMMONIA IN SEAWATER AT $5^{\circ} \mathrm{C}$ and $30^{\circ} \mathrm{C}$ 


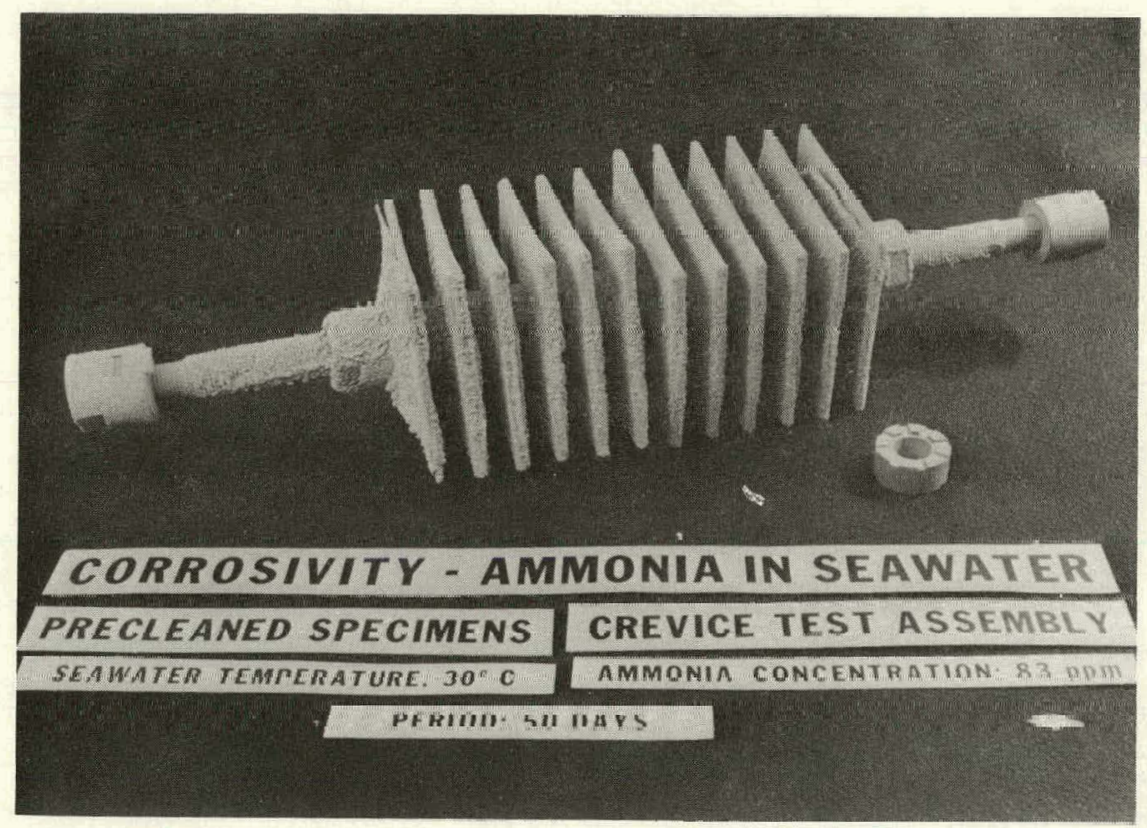

Figure IX-8

SCALE FORMATION ON CREVICE TEST ASSEMBLY

83 NUII AMMONIA IN SEAWATER AT $30^{\circ} \mathrm{C}$ 


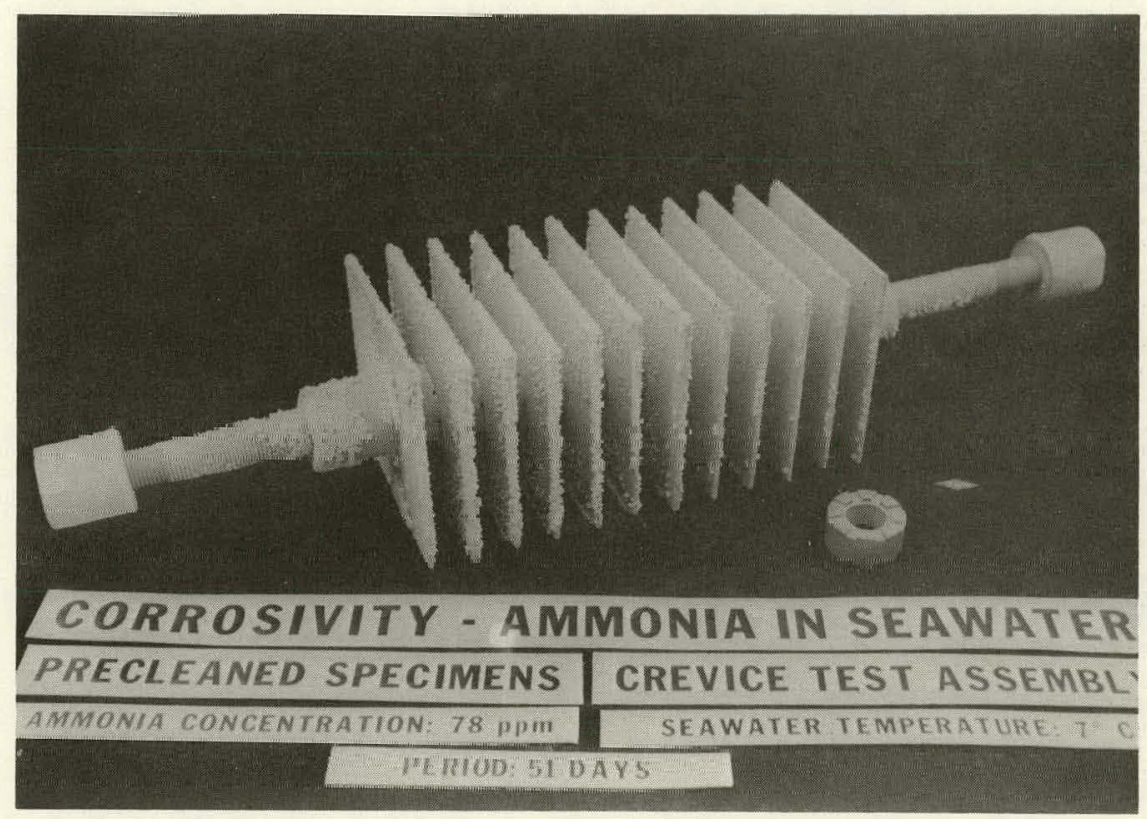

Figure IX-9

SCALE FORMATION ON CREVICE TEST ASSEMBLY 78 ppm AMMONIA IN SEAWATER AT $5^{\circ} \mathrm{C}$ 


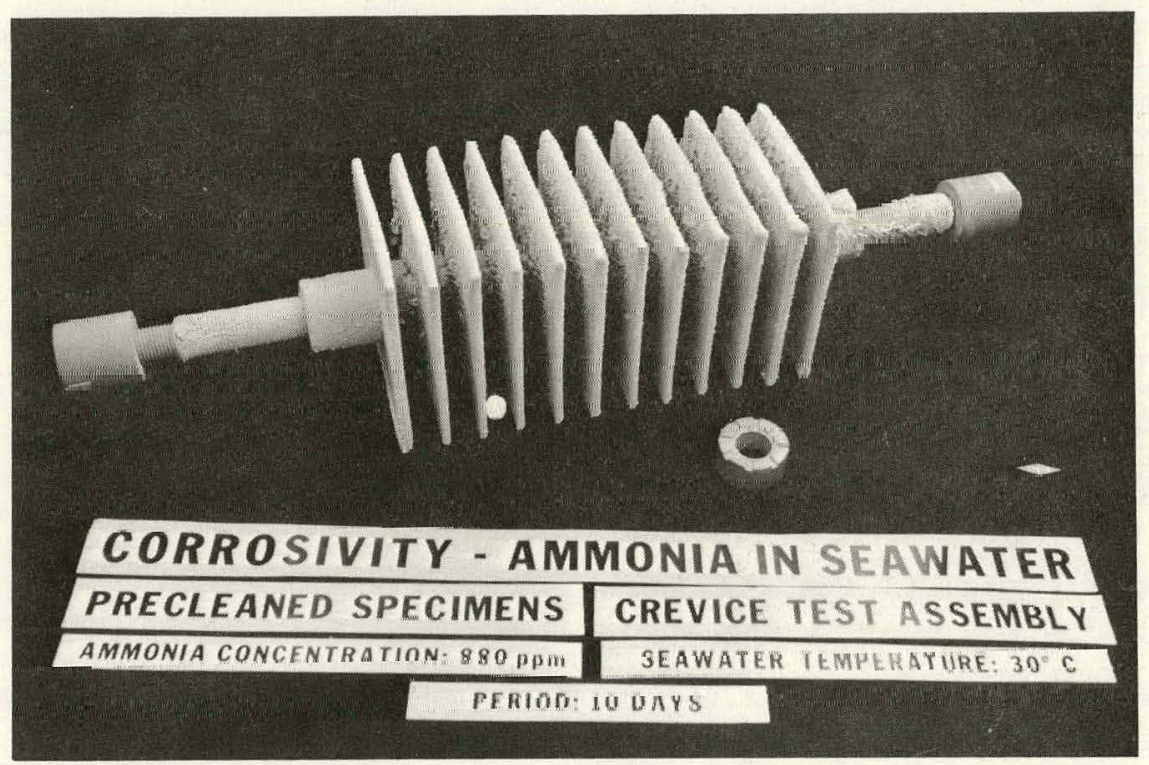

Figure IX-10

SCALE FORMATION ON CREVILE' 'I'E'S'I' ASSEMBLY

$880 \mathrm{ppm}$ AMMONIA IN SEAWATER AT $30^{\circ} \mathrm{C}$ 


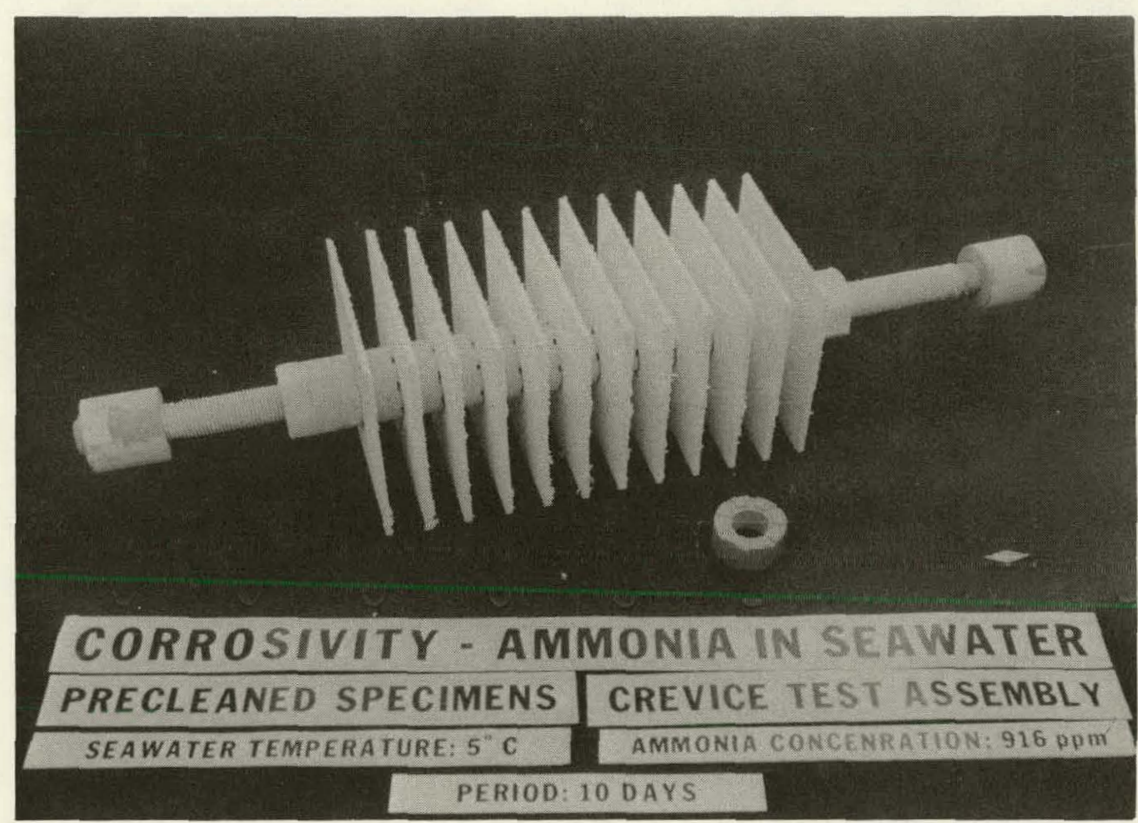

Figure IX-11

SCALE FORMATION ON CREVICE TEST ASSEMBLY

916 pPM AMMONIA IN SEAWATER AT $5{ }^{\circ} \mathrm{C}$ 


\section{Distribution for ANL/OTEC-BCM-004}

Interna 1:

P. H. Benson

J. J. Roberts

J. B. Darby, Jr.

N. F. Sather

J. E. Draley (12)

A. Thomas

B.R.T. Frost

ANL Contract Copy

A. B. Krisciunas

ANL Libraries (5)

G. F. Popper

TIS Files (6)

Externa1:

DOE-TIC, for distribution per UC-64 (412)

Manager, Chicago Operations and Regional Office, DOE

Chief, Office of Patent Cnunsel, DOE-CORO

President, Argonne Universities Association

J. Hilbert Anderson, Sea Solar Power, Inc.

M. Kent Anderson, Trane Air Conditioning

Takaaki Anzai, Florida Institute of Technology

W. H. Avery, Applied Physics Laboratory, Johns Hopkins University

E. Barsness, Westinghouse Electric Corporation

James 0. Bates, Energy Technology Engineering Center

Kenneth J. Bell, Oklahoma State University

Robert A. Bonewitz, Aluminum Company of America

R. Cohen, US-DOE, Div. of Centra1 Solar Technology

William A. Corpe, Columbia University

R. S. Dalrymple, Reynolds Metals Company

G. J. Danek, Annapolis, Maryland

James Denton, TRW Systems and Energy

John DePalma, U. S. Naval Oceanngraphic office

Stephen Dexter, University of Delaware

John G. Fetkovich, Carnegie-Mellon University

Harry Foust, Trane Air Conditioning

Malcom D. Fraser, Intertechnology Corporation

John Gertz, Westinghouse Électric Corporation

W. D. Grimes, Dow Chemical Company

Sigmund Gronich, US-DOE, Div. of Central Solar Technology

P. H. Hadley, Jr., Gibbs \& Cox, Inc.

L. W. Hallanger, Research Corporation, University of Hawaii

William Harte, Florida Atlantic University

William E. Heronemus, University of Massarhisetts

F. K. Hill, Applied Physics Laboratory, Johns Hopkins University

Jules Hirshman, Tracor Marine

J. F. Jenkins, Civil Engineering Laboratory

․ H. Kincloki, US-DOE, Div. of Centra $\perp$ Solar Technology

Robert E. Lacey, Southern Research Institute

F. L. LaQue, Verona, New Jersey

Abrahim Lavi, Carnegie-Mellon University

T. S. Lee, International Nickel Company

Murray Leitner, Lockheed Missiles and Space Co., Inc.

Lloyd Lewis, US-DOE, Div. of Central Solar Technology

Brenda Little, NORDA

D. Lott, Naval Coastal Systems Center

Richard N. Lyon, Oak Ridge National Laboratory 
Frank Mathews, Colorado School of Mines

William F. McIlhenny, Dow Chemical Company

John W. Miche1, Oak Ridge National Laboratory

Ralph Mitchell, Harvard University

Robert L. Molinari, NOAA/AMOL

John Morse, University of Miami

John Nicol, Arthur D. Little, Inc.

Merle Olmsted, General Electric Company

T. B. O'Neill, Civil Engineering Laboratory

David Price, U. S. National Oceanic \& Atmospheric Administration

W. W. Pritsky, Aluminum Association

J. F. Rynewicz, Lockheed Missiles and Space Co., Inc.

Donald Sasscer, University of Puerto Rico

C. F. Schrieber, Dow Chemical Company (3)

H. H. Sephton, University of California at Berkeley

William Sheppard, NOAA Data Buoy Office

Wilbur Sherwood, US-DOE, Div. of Central Solar Technology

J. E. Snyder, TRW Systems and Energy

Frank Spiehler, NOAA Data Buoy Office.

T. J. Summerson, Kaiser Aluminum and Chemical Corp.

R. B. Teel, Chatham, New Jersey

D. L. Thomas, Radiation Management Corporation

Fred Vukovich, Research Triangle Institute

J. Paul Walsh, Value Engineering Company

E. T. Wanderer, Aluminum Company of America

Ralph Williams, PRC Energy Analysis Co.

David C. White, Florida State University

Hank White, Natural Energy Laboratory of Hawaii 